Prepared in cooperation with the Bureau of Indian Affairs

\title{
Groundwater, Surface-Water, and Water-Chemistry Data from the C-Aquifer Monitoring Program, Northeastern Arizona, 2005-2011
}

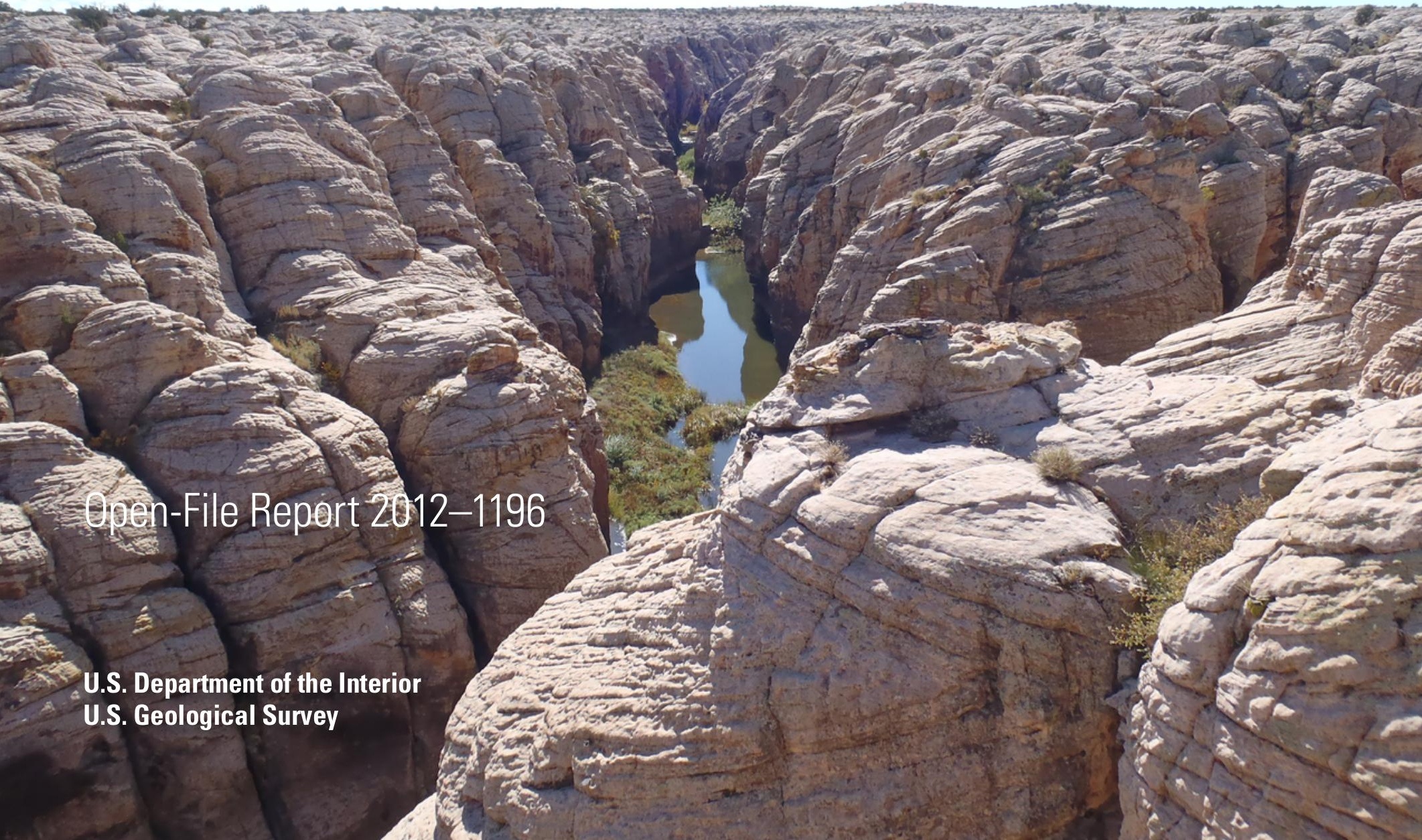


Photograph of Chevelon Creek, Arizona (USGS photograph taken by Jamie P. Macy). 


\section{Groundwater, Surface-Water, and Water- Chemistry Data from the C-Aquifer Monitoring Program, Northeastern Arizona, 2005-2011}

By Christopher R. Brown and Jamie P. Macy

Prepared in cooperation with the Bureau of Indian Affairs

Open-File Report 2012-1196 


\title{
U.S. Department of the Interior KEN SALAZAR, Secretary
}

\author{
U.S. Geological Survey \\ Marcia K. McNutt, Director
}

U.S. Geological Survey, Reston, Virginia: 2012

Revised 2013

This report and any updates to it are available online at:

http://pubs.usgs.gov/of/2012/1196/

For more information on the USGS - the Federal source for science about the Earth, its natural and living resources, natural hazards, and the environment, visit http://www.usgs.gov or call 1-888-ASK-USGS.

For an overview of USGS information products, including maps, imagery, and publications,

visit http://www.usgs.gov/pubprod

To order this and other USGS information products, visit http://store.usgs.gov

Any use of trade, product, or firm names is for descriptive purposes only and does not imply endorsement by the U.S. Government.

Although this report is in the public domain, permission must be secured

from the individual copyright owners to reproduce any copyrighted materials contained within this report.

Suggested citation:

Brown, C.R., and Macy, J.P., 2012, revised 2013, Groundwater, surface-water, and water-chemistry data from C-aquifer monitoring program, northeastern Arizona, 2005-2011: U.S. Geological Survey Open-File Report 2012-1196, v.1.1, $38 \mathrm{p}$. 


\section{Contents}

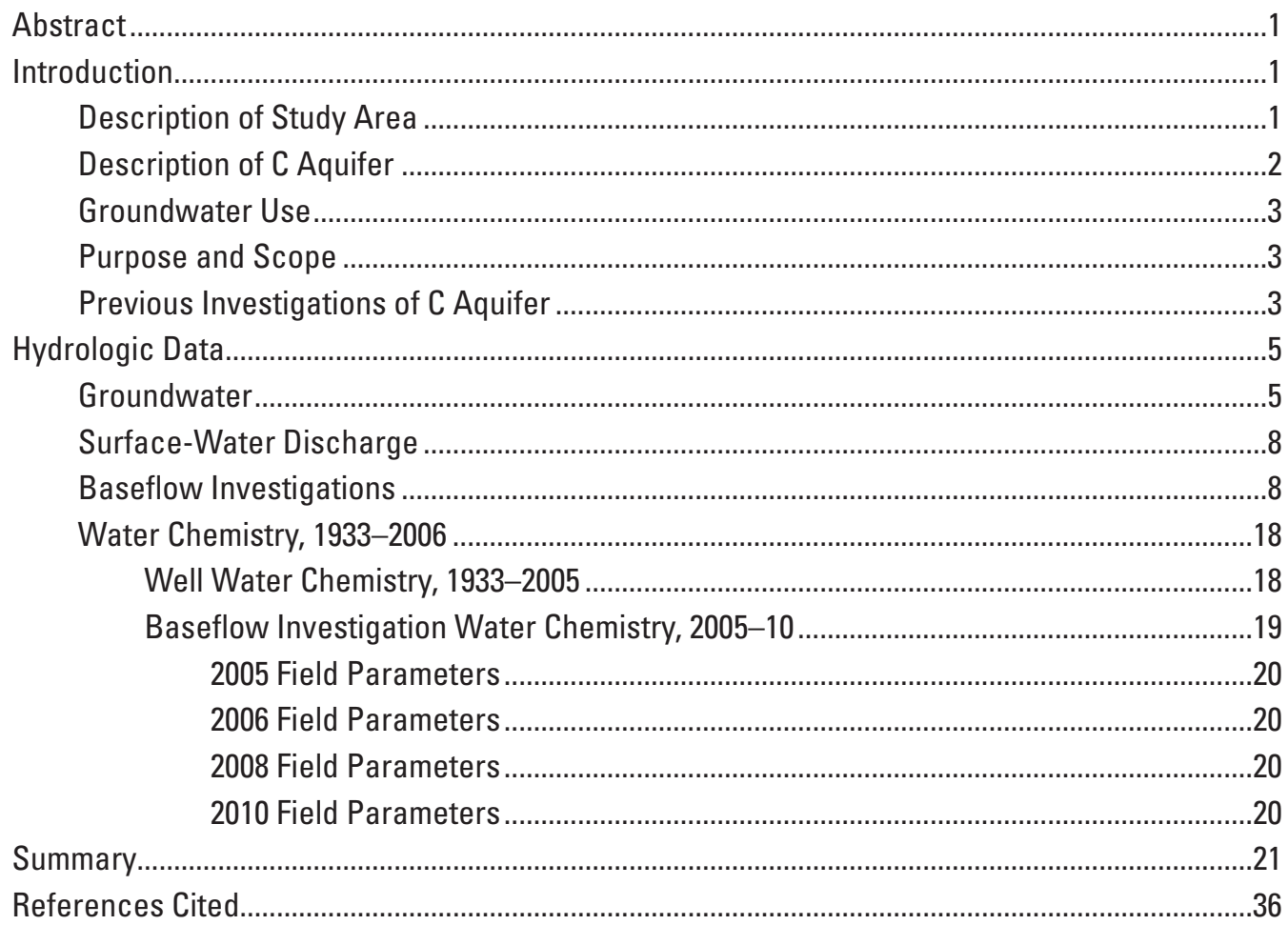

\section{Figures}

1. Approximate extent of the $C$ Aquifer and location of the study area, northeastern Arizona ..2

2. Generalized stratigraphic section of rock units in the study area and surrounding areas, northeastern Arizona.................................................................

3. Generalized hydrogeologic section of the Little Colorado River Basin and adjoining areas near Flagstaff, Arizona ……………...........................................5

4. Locations of observation wells and discontinued streamflow-gaging station sites included in this study, northeastern Arizona...................................................................

5. Measured water levels (1965-2010) in observation-well network, $\mathrm{C}$ aquifer, northeastern Arizona

6. Measured water levels $(1950,1960$, or 1965-2010) in observation-well network, $C$ aquifer, northeastern Arizona

7. Measured water levels (1980-2010) in observation-well network,

$C$ aquifer, northeastern Arizona

8. Measured water levels (1995-2010) in observation-well network,

$C$ aquifer, northeastern Arizona

9. Measured water levels (1965 or 2005-2011) in observation-well network,

$C$ aquifer, northeastern Arizona

10. Measured water levels (2005-2011) in observation-well network, $\mathrm{C}$ aquifer, northeastern Arizona 
11. Measured and continuously recorded water levels (1965-2011)

in observation-well network, C aquifer, northeastern Arizona

12. Measured and continuously recorded water levels (2005-2011) in observation-well network, $\mathrm{C}$ aquifer, northeastern Arizona

13. Locations of baseflow investigation sites (green and orange dots) included in this study, northeastern Arizona.

14. Discharge by river miles upstream of the confluence with the Little Colorado River (LCR) for baseflow investigation sites along Chevelon Creek and Clear Creek, northeastern Arizona

15. Specific conductance by river miles upstream of the confluence with the Little Colorado River (LCR) for baseflow investigation sites along Chevelon Creek and Clear Creek, northeastern Arizona

\section{Tables}

1. Well locations and selected construction data for $\mathrm{C}$-aquifer wells included in this study, northeastern Arizona......

2. Period of record and drainage areas for historic streamflow-gaging stations included in this study, northeastern Arizona.

3. Daily mean discharge for Clear Creek near Winslow, AZ (09399000), calendar year 2005...22

4. Daily mean discharge for Clear Creek near Winslow, AZ (09399000), calendar year 2006...23

5. Daily mean discharge for Clear Creek near Winslow, AZ (09399000), calendar year 2007...24

6. Daily mean discharge for Clear Creek below McHood Lake, near Winslow, AZ (09399100), calendar year 2005 ...

7. Daily mean discharge for Clear Creek below McHood Lake, near Winslow, AZ (09399100), calendar year 2006

8. Daily mean discharge for Clear Creek below McHood Lake, near Winslow, AZ (09399100), calendar year 2007

9 Daily mean discharge for Chevelon Creek near Winslow, AZ (09398000), calendar year 2005

10. Daily mean discharge for Chevelon Creek near Winslow, AZ (09398000), calendar year 2006

11. Daily mean discharge for Chevelon Creek near Winslow, AZ (09398000), calendar year 2007

12. Locations and descriptions of $\mathrm{C}$-aquifer baseflow investigation sites included in this study, northeastern Arizona.

13. Measured field parameters at $\mathrm{C}$-aquifer baseflow investigation sites along Clear Creek, Chevelon Creek, and Little Colorado River (LCR), northeastern Arizona.

14. Physical and chemical analyses of water samples from selected $\mathrm{C}$-aquifer wells, Little Colorado River basin, northeastern Arizona

15. Physical and chemical analyses of spring and surface-water samples from the 2005 and 2006 baseflow investigations along Clear Creek, Chevelon Creek, and a reach of the Little Colorado River, northeastern Arizona. 


\title{
Groundwater, Surface-Water, and Water-Chemistry Data from the C-Aquifer Monitoring Program, Northeastern Arizona, 2005-2011
}

\author{
By Christopher R. Brown and Jamie P. Macy
}

\section{Abstract}

The $\mathrm{C}$ aquifer is a regionally extensive multiple-aquifer system supplying water for municipal, agricultural, and industrial use in northeastern Arizona, northwestern New Mexico, and southeastern Utah. An increase in groundwater withdrawals from the $\mathrm{C}$ aquifer coupled with ongoing drought conditions in the study area increase the potential for drawdown within the aquifer. A decrease in the water table and potentiometric surface of $\mathrm{C}$ aquifer is illustrated locally by the drying up of Obed Meadows, a natural peat deposit, and Hugo Meadows, a natural wetland, both south of Joseph City, Arizona. Continual increase in water use from the $\mathrm{C}$ aquifer, including a planned increase in pumpage by the City of Flagstaff, is justification for continued monitoring of the $\mathrm{C}$-aquifer system in order to quantify physical and chemical responses to pumping stresses.

Fifteen of the $35 \mathrm{C}$-aquifer wells analyzed had water-level data sufficient for percentage difference calculation for 2005-11. Change in water level as a percentage of the initial water-level measurement for these 15 wells ranged from about -0.2 to about -0.5 percent. For historical water-level data, changes in water levels were greatest around pumping centers, as indicated by a -97.0 feet (percentage difference of -16.5 percent) change over the period of record (1962-2005) for the Lake Mary 1 Well near Flagstaff, Arizona. In more rural areas of the $\mathrm{C}$ aquifer, water levels showed less change for both the temporal focus of this report (2005-11) and for historical values.

Continuous records of surface-water discharge from 2005 to 2007 for three discontinued streamflow-gaging stations (Clear Creek near Winslow, AZ, 09399000; Clear Creek below McHood Lake near Winslow, AZ, 09399100; and Chevelon Creek near Winslow, AZ, 09398000) were tabulated. For the period of record, Clear Creek near Winslow, AZ, and Chevelon Creek near Winslow, $\mathrm{AZ}$, showed seasonal discharge distributions indicative of natural streams in the southwestern United States. Clear Creek below McHood Lake near Winslow, AZ, showed discharge distribution indicative of perennial spring flow with little variation annually.

Physical and chemical data collected during four baseflow investigations (summer 2005, summer 2006, summer 2008, and winter 2010) conducted on Clear Creek, Chevelon Creek, and a portion of the Little Colorado River were compiled and analyzed. Data from 7 sampling sites established on the Little
Colorado River, 11 sites along Chevelon Creek, and 14 sites along Clear Creek were included. For the four baseflow investigations presented, a 2,000-3,000 microsiemens per centimeter increase in specific conductance was measured in Chevelon Creek from near its headwaters to the confluence with the Little Colorado River because of the contribution of highly conductive spring discharge. Clear Creek showed a less consistent pattern of increase in specific conductance with distance, but still exhibited changes on the order of 5,000 microsiemens per centimeter over just a few river miles

Water-chemistry data for selected wells and baseflow investigations sites are presented. No well samples analyzed exceeded the U.S. Environmental Protection Agency Maximum Contaminant Level standards for drinking water, but several samples exceeded Secondary Maximum Contaminant Level standards for chloride, fluoride, sulfate, iron, and total dissolved solids.

\section{Introduction}

The $\mathrm{C}$ aquifer is a regionally extensive multiple-aquifer system supplying water for municipal, agricultural, and industrial use. Increases in water use and/or drought conditions have been reported to cause a lowering of the $\mathrm{C}$-aquifer potentiometric and water-table surfaces (Bills and others, 2000). This decline in water level is observed in monitoring wells and is illustrated in the drying up of Obed Meadows, a natural peat deposit, and Hugo Meadows, a natural wetland - both south of Joseph City, Arizona (Donald J. Bills, U.S. Geological Survey, oral commun. 2011). To address these concerns, the U.S. Geological Survey (USGS), in cooperation with the Bureau of Indian Affairs, developed a long-term monitoring plan in 2005 for the $\mathrm{C}$ aquifer in the region of Holbrook to Flagstaff along the Interstate 40 (I-40) corridor to establish baseline groundwater and surface-water conditions.

\section{Description of Study Area}

The C-aquifer multiple-aquifer system is located on the Colorado Plateau physiographic province in northeastern Arizona, northwestern New Mexico, and southeastern Utah (fig. 1). The study area is within the Little Colorado River (LCR) Basin, but is focused on the region between Holbrook and Flagstaff along the I-40 corridor. 


\section{Description of C Aquifer}

The $\mathrm{C}$ aquifer is named after the primary water-bearing rock unit within the aquifer, the Coconino Sandstone, but the saturated and hydraulically connected portions of the Kaibab Formation, the Schnebly Hill Formation, and the Upper and Middle Supai Formations constitute part of the C aquifer (fig. 2; Bills and others, 2000; Bills and Flynn, 2002; Hart and others, 2002). The $C$ aquifer has an areal extent of greater than 27,000 $\mathrm{mi}^{2}$, generally conforming to the surface-water drainage of the LCR Basin (fig. 1; Hart and others, 2002; Hoffmann and others, 2005). The aquifer extends both beyond the southern boundary of the LCR Basin into the Verde and Salt River Basins, conforming to the outcrops of Pennsylvanian and Permian age rocks, and beyond the north-northwestern boundary of the LCR Basin into Utah (fig. 1). In the northeastern part of the study area, the $\mathrm{C}$ aquifer is about 400-600 $\mathrm{ft}$ thick and thins eastward into New Mexico (Cooley and others, 1969; Hart and others,

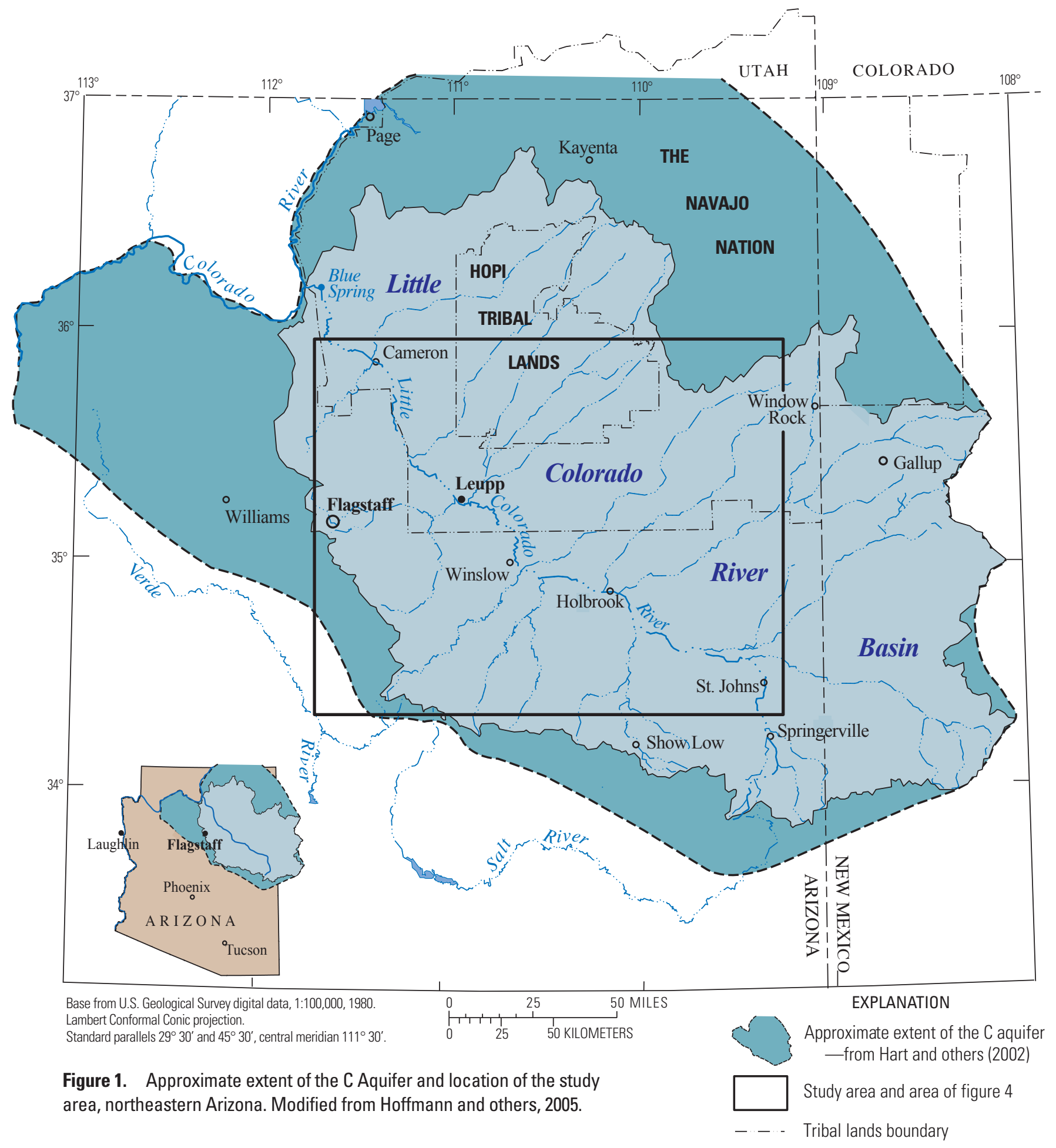


2002). Paleozoic rocks are relatively unexplored eastward into New Mexico, and water-level data are sparse for areas southeast of Gallup, New Mexico; therefore, the boundary of the C aquifer is uncertain in these locations (Hart and others, 2002). West of the LCR Basin (fig. 1), the C aquifer is dry except for isolated areas of perched water (McGavock and others, 1986; Hart and others, 2002). In the eastern and northern parts of the study area, the DeChelly and Glorieta Sandstones interfinger with the Coconino Sandstone to form the majority of the $\mathrm{C}$ aquifer water-bearing zone (fig. 3). This study concentrates on the portion of the $\mathrm{C}$ aquifer within the LCR Basin (fig. 1).

The $\mathrm{C}$ aquifer is anisotropic and unconfined in the majority of the study area; however, portions of the $\mathrm{C}$ aquifer are overlain by less permeable units of the Moenkopi, the Chinle, and the Bidahochi Formations, and by unfractured volcanics (Bill and others, 2000; S.S. Papadopulos and Associates, Inc., 2005). These formations are considered to be confining layers, with negligible amounts of downward leakage to the $\mathrm{C}$ aquifer, thus, the majority of recharge to the $\mathrm{C}$ aquifer occurs at either subaerial exposures or where the surface lithology is fractured (Hart and others, 2002). Known confined conditions for the $C$ aquifer occur (1) in the Black Mesa area where the $\mathrm{C}$ aquifer is overlain by nearly impermeable Chinle and Moenkopi Formations, (2) in the southeastern part of the LCR Basin where the Bidahochi Formation is underlain by the Chinle and Moenkopi Formations, and (3) near the Woody Mountain and Lake Mary areas near Flagstaff where the volcanics are unfractured.

\section{Groundwater Use}

Groundwater development in the $\mathrm{C}$ aquifer has increased in the study area since the 1940s (Hart and others, 2002). Currently, the City of Flagstaff and surrounding communities, three regional power plants, and a large paper mill near Snowflake, Arizona, are substantial users of C-aquifer water (S.S. Papadopulos and Associates, Inc., 2005). Discharge from $C$ aquifer springs provides baseflow for Clear Creek, Chevelon Creek, and the LCR, as shown in Brown and others (1978). Baseflow in these streams provides habitat for a myriad of species, including the endangered northern leopard frog (Rana pipiens), the speckled dace (Rhinichthys osculus), and the Little Colorado spinedace (Lepidomeda vittata) (U.S. Fish and Wildlife Service, 2011).

\section{Purpose and Scope}

This report presents groundwater, surface-water, and water-quality data collected during 2005 to the end of water year 2011 from an ongoing monitoring of the $\mathrm{C}$ aquifer near Hunt Valley along the I-40 corridor westward to Flagstaff. The report also includes historical water-level data and chemical analyses dating back to 1933 from wells developed in the $\mathrm{C}$ aquifer. Data presented include: (1) water-level data from 35 wells completed in the $\mathrm{C}$ aquifer, (2) surface-water discharge data from 3 discontinued streamflow-gage sites on
Chevelon and Clear Creek (Clear Creek near Winslow, AZ, 09399000; Clear Creek below McHood Lake, near Winslow, AZ, 09399100; and Chevelon Creek near Winslow, AZ, 09398000), (3) water chemistry from selected well sites and baseflow investigation sites, and (4) water-quality parameters and discharge measurements from 4 baseflow investigations conducted on reaches of Clear Creek, Chevelon Creek, and the LCR. The USGS C-aquifer Monitoring Program is ongoing and will remain active dependent upon the availability of funds.

\section{Previous Investigations of C Aquifer}

$\mathrm{C}$-aquifer hydrogeology and water use have been described in a number of USGS and non-USGS reports (Darton, 1910; Gregory, 1916; Harrell and Eckel, 1939; Johnson, 1962; Cooley and others, 1969; Mann, 1976, 1979, 1983; Appel and Bills, 1980; McGavock and others, 1986; Bills and Flynn, 2002; Bills and others, 2000, 2007). Hart and others (2002) compiled data on the $\mathrm{C}$ aquifer in the LCR Basin and parts of the Verde and Salt River Basins and produced a groundwater budget and a generalized hydrogeological characterization of the $\mathrm{C}$ aquifer. Several private consulting firms (Peter Mock Groundwater Consulting, 2003; Southwest Ground-water Consultants, Inc., 2003) prepared a collaborative report for the Bureau of Reclamation (BOR) assessing the water supply needs of the western part of the Hopi Tribal Lands and the Navajo Nation. The report contains estimates of population growth and water demand for the study area through 2050. Suggestions for enhanced conservation practices and possible alternative water sources were made. Geological, hydrological, and chemical data from the $\mathrm{C}$ aquifer near Leupp, Arizona, were analyzed and presented by Hoffmann and others (2005) as part of a collaborative study conducted by the BOR, the USGS, the U.S. Fish and Wildlife Service, the Office of Surface Mining, and Native American tribes in order to assess the effects of proposed new development. Leake and others (2005) created a numerical groundwater change model to simulate possible effects of proposed withdrawals from $\mathrm{C}$ aquifer near Leupp. The model used two pumping scenarios to simulate the amount of discharge depletion for surface-water features including Clear Creek, Chevelon Creek, and the LCR. The model showed computed depletion in lower Chevelon Creek is less than that in lower Clear Creek because Chevelon Creek is more distant from the withdrawal locations, and the drawdown first reaches Clear Creek. Another groundwater-flow model of the $\mathrm{C}$ aquifer in northeastern Arizona and northwestern New Mexico was developed by S.S. Papadopulos and Associates, Inc. (2005). This model also simulated the possible effects of a proposed increase in withdrawals from the $\mathrm{C}$ aquifer near Leupp. The model constructed by S.S. Papadopulos and Associates, Inc. (2005) showed little impact on wells outside the proposed well field, but "significant" impact on perennial reaches of Chevelon and Clear Creeks for the pumping scenarios tested. 


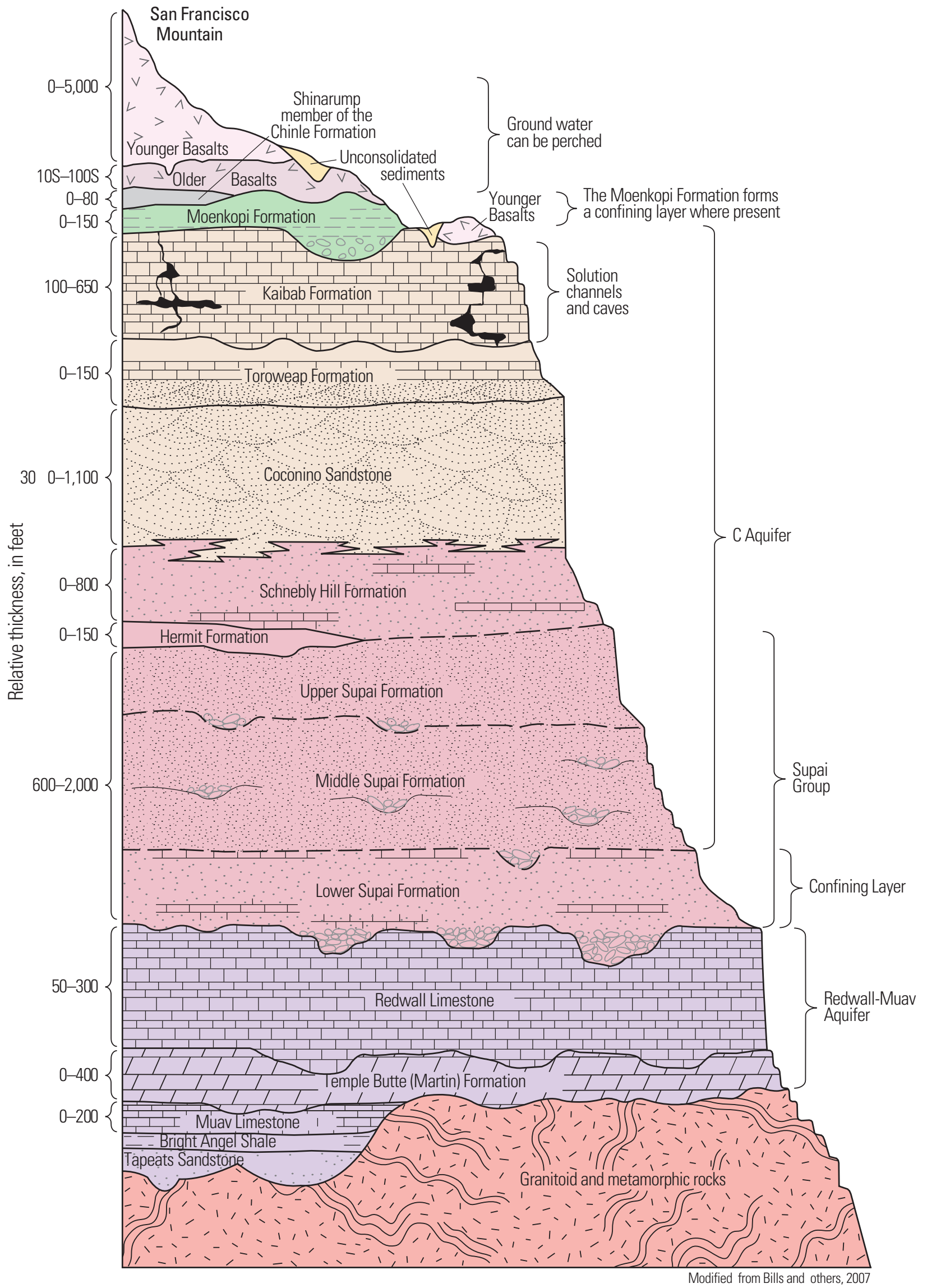

Figure 2. Generalized stratigraphic section of rock units in the study area and surrounding areas, northeastern Arizona. 


\section{Hydrologic Data}

All the hydrologic data presented in this report were queried from the USGS National Water Information System (NWIS) and are available publicly online (U.S. Geological Survey, 2012, accessed August 20, 2012, at http://waterdata.usgs.gov/nwis).

\section{Groundwater}

Groundwater levels were monitored to determine the effects of withdrawal and drought on the $\mathrm{C}$-aquifer potentiometric and water-table surfaces. The well network within the $\mathrm{C}$-aquifer Monitoring Program consists of 35 wells distributed about the study area (table 1; fig. 4). Seventeen wells are visited quarterly to retrieve depth-to-water measurements (below land surface). The remaining 18 wells within the network have not been visited since 2006 because of limited funding. Depth-to-water is measured from an established measuring point at the well head using a calibrated Solinst ${ }^{\mathbb{}}$ Model 101 electric measuring tape (Solinst Canada Ltd., Georgetown, Ontario, Canada). Within the network, 5 of the 30 wells are equipped for continuous water-level monitoring, including an upgrade for real-time data telemetry (table 1). Test wells were drilled at three well-cluster sites on the Navajo Nation near Leupp between January and April

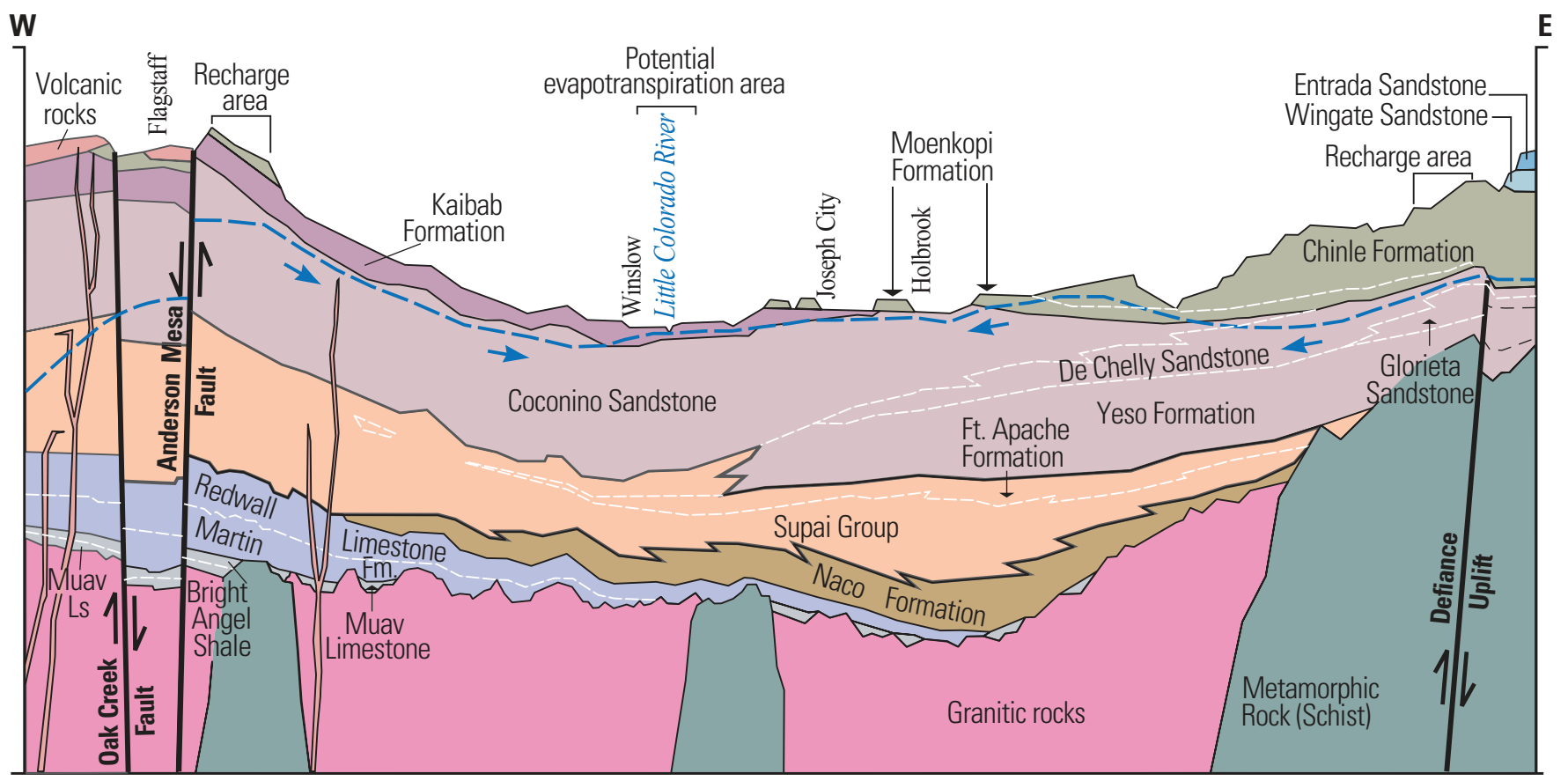

EXPLANATION

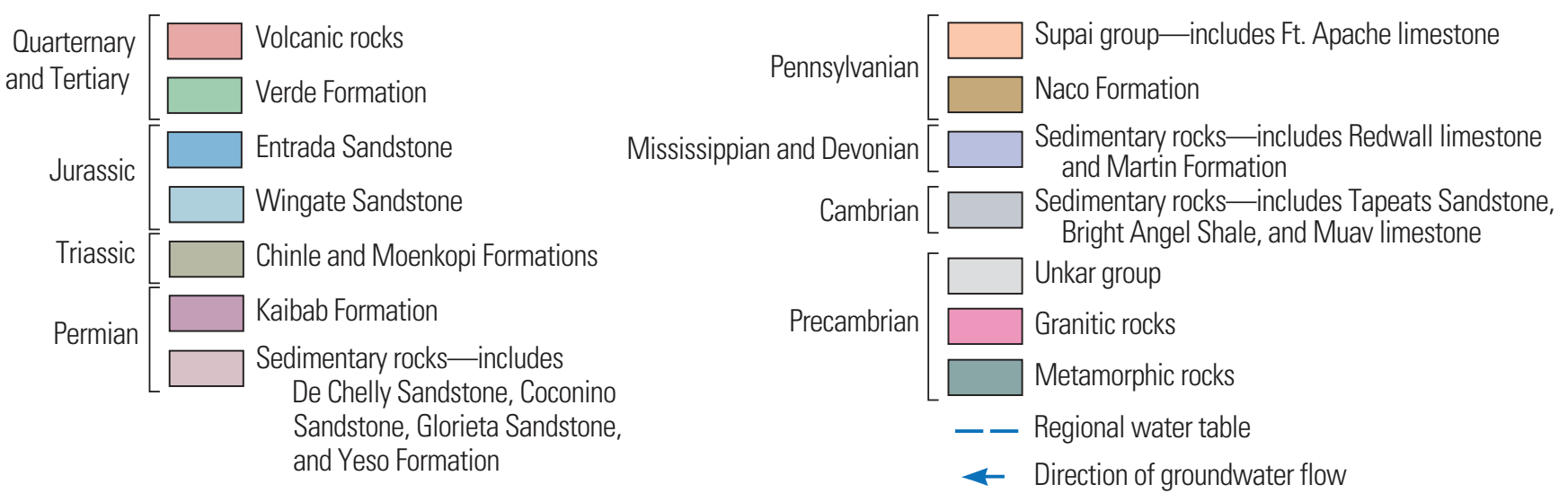

Figure 3. Generalized hydrogeologic section of the Little Colorado River Basin and adjoining areas near Flagstaff, Arizona, along Interstate 40 to the Arizona-New Mexico border. Modified from Billingsley and others (1980) and Hart and others (2002) 
Table 1. Well locations and selected construction data for $\mathrm{C}$-aquifer wells included in this study, northeastern Arizona.

[Latitude and longitude are in degrees, minutes, and seconds and referenced to NAD 83; ft, feet; ft bls, feet below land surface; ---, information not available; N/A, not applicable; USGS, U.S. Geological Survey; BOR, Bureau of Reclamation]

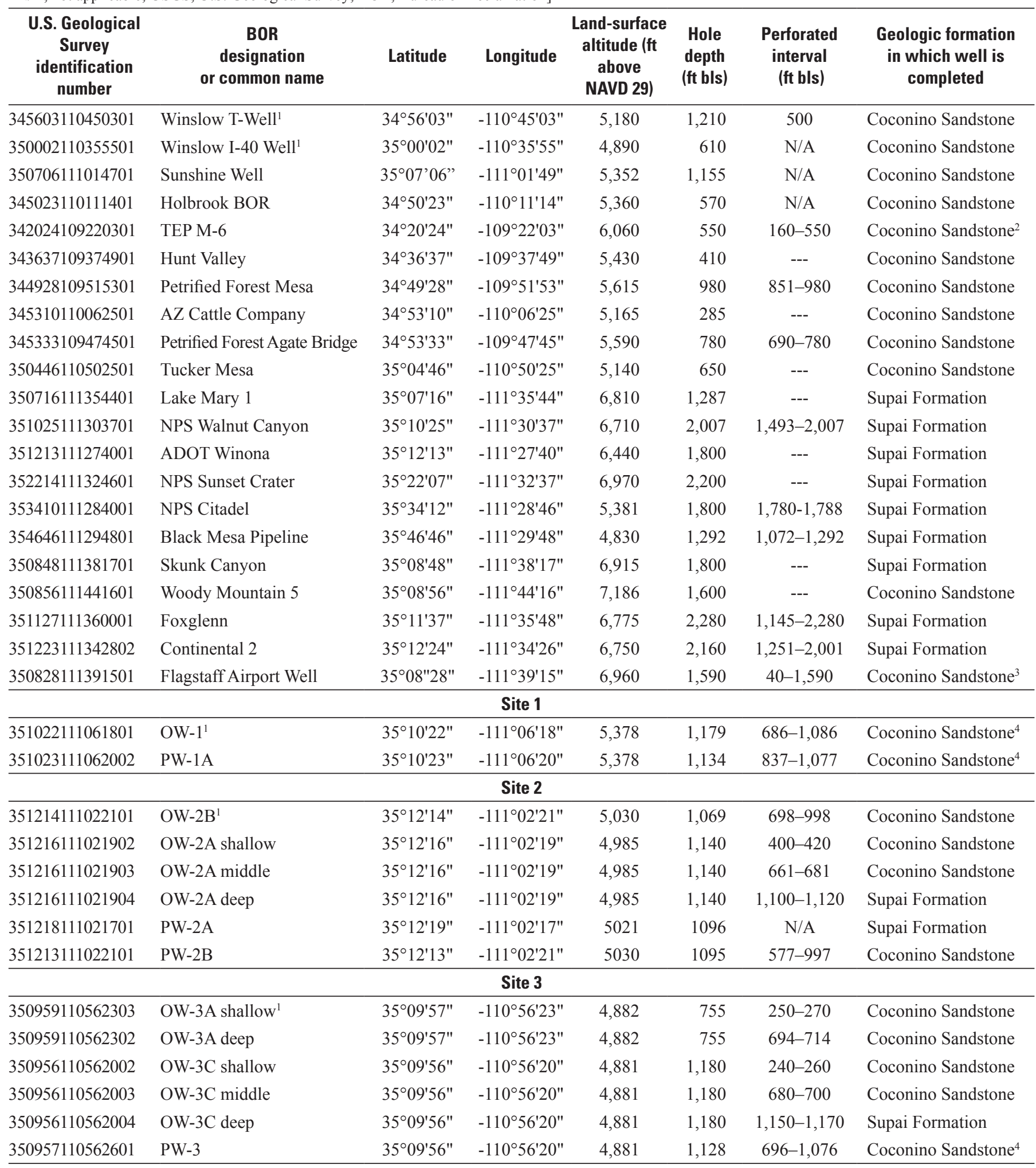

${ }^{1}$ Continuously monitored sites.

${ }^{2}$ Coconino Sandstone overlain by Kaibab Limestone

${ }^{3}$ Coconino Sandstone overlain by Kaibab Limestone and Toroweap Formation

${ }^{4}$ Interfingered Coconino Sandstone and Schnebly Hill Formation 
2005 (fig. 4). The three well clusters are near a proposed site of a C-aquifer well field and were intended to provide information for characterizing hydrogeologic properties of the $\mathrm{C}$ aquifer in that area (Hoffmann and others, 2005). One well per well-cluster site is a continuously monitored well: Well OW-1 for Site 1, Well OW-2B for Site 2, and Well OW-3A shallow for Site 3 (fig. 4). The Winslow T-Well and Winslow I-40 Well are the other two continuously monitored sites.

Water levels are measured manually on a quarterly basis at the five continuously monitored wells. Manual and continuous water-level measurements are available online (http:// waterdata.usgs.gov/nwis/gw).

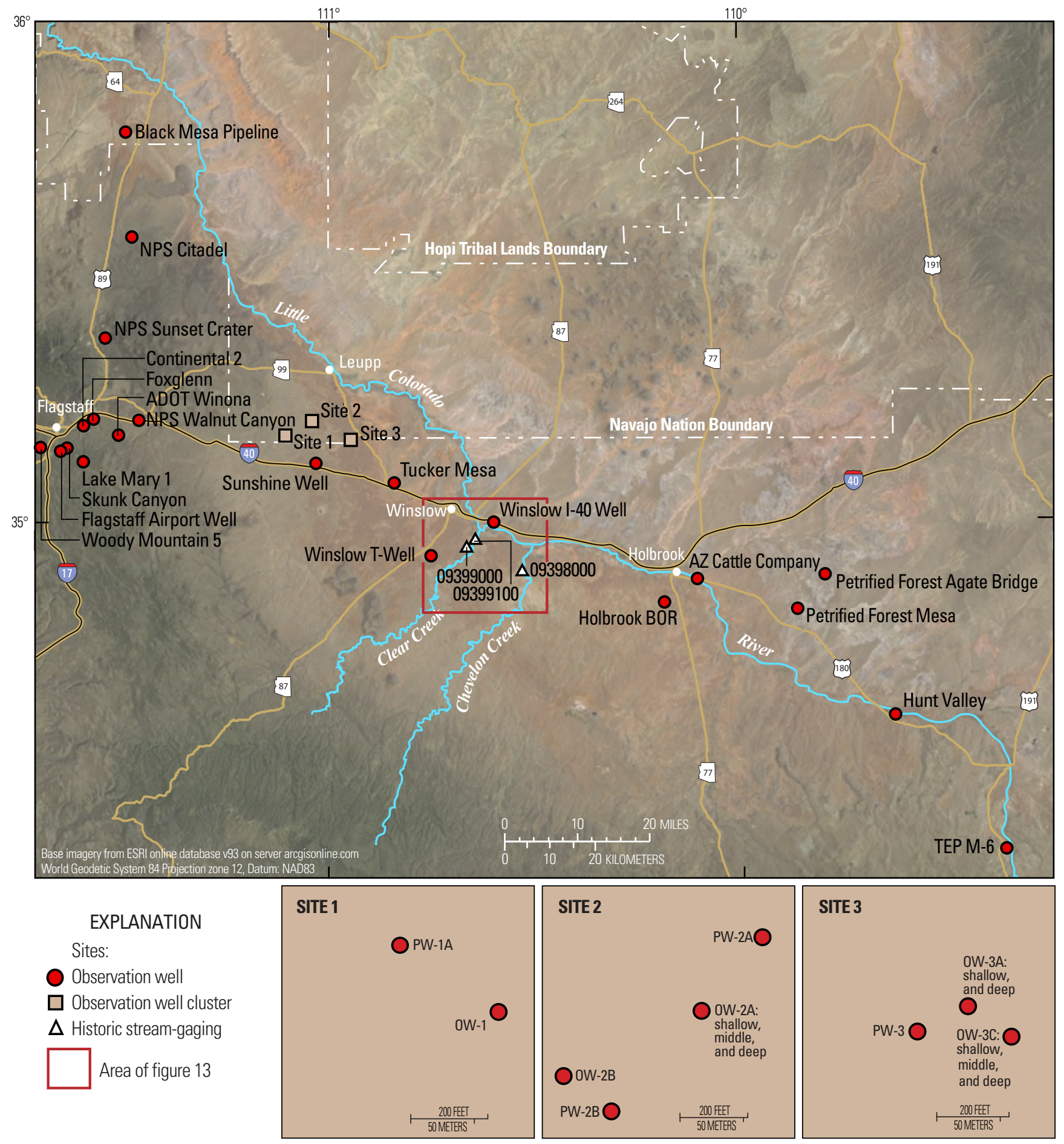

Figure 4. Locations of observation wells and discontinued streamflow-gaging station sites included in this study, northeastern Arizona. A detailed view of the well cluster sites near Leupp is shown below the map. Sections modified from Hoffmann and other, 2005. 
The period of groundwater-level record varies from well to well. Historical depth-to-water measurements for wells previously monitored within the $\mathrm{C}$-aquifer Monitoring Program were plotted to determine changes in water level over time. Depth-to-water increased around Flagstaff, a major pumping center, although little to no change was observed in more remote wells. Fifteen of the $35 \mathrm{C}$-aquifer wells analyzed had water-level data sufficient for percentage of difference calculations for 2005-11. Change in water level as a percentage of the initial water-level measurement for these 15 wells ranged from about -0.2 to about -0.5 percent. For historical water-level data, changes in water levels were greatest around pumping centers, as indicated by a $-97.0 \mathrm{ft}$ (percentage difference of -16.5 percent) change over the period of record (1962-2005) for the Lake Mary 1 Well near Flagstaff. In more rural areas of the $\mathrm{C}$ aquifer, water levels showed less change for both the temporal focus of this report (2005-11) and for historical values. Sporadic data through the period of record make water-level trends difficult to quantify for the remaining wells within the network (figs. 5-10). More water-level data are necessary to evaluate water-level trends for a greater portion of the study area.

In 2006, five observation wells (Winslow T-Well, Winslow I-40 Well, Well OW-1, Well OW-2B, and Well OW-3A shallow) (fig. 4) were fitted with continuously logging pressure transducers that collect data at 15 -min intervals (figs 11 and 12). Seasonal variation is visible in all five hydrographs, but little water-level change is seen during the period of record (fig. 12). Of the five continuously monitored wells, water levels for the end of water year 2011 range from $37.6 \mathrm{ft}$ at the Winslow I-40 Well to $614.8 \mathrm{ft}$ at Well OW-1. The greatest change in depth-to-water for the period of 2005-11 (-2.5 ft) was recorded at the Winslow I-40 Well. The greatest positive change in depth-to-water for the period of 2005-11 (0.2 ft) occurred at the well OW-1. Depth-to-water for the Winslow T-Well has increased by about $2 \mathrm{ft}$ since monitoring began in 1969 (fig. 11), however, if the period of 2005-11 only is analyzed, little to no change in water level is indicated (fig. 12). Depth-to-water for the Winslow I-40 Well has changed by $-1.6 \mathrm{ft}$ since monitoring began in 1972 (fig. 11).

\section{Surface-Water Discharge}

Surface-water discharge data can show the qualitative reaction of a stream reach to runoff produced by precipitation or snowmelt and trends in the amount of discharge over time. Furthermore, surface-water discharge conditions during times when there is no overland runoff can provide information on natural baseflow, which is the discharge of $\mathrm{C}$-aquifer water from springs and seeps. Because the surfacewater discharge through the perennial reaches of Clear Creek, Chevelon Creek, and the reach of the LCR between these two tributaries are fed by springs, surface-water discharge data can also show trends in baseflow. Streamflow data were monitored for too short of a time during 2005-11 for the $\mathrm{C}$-aquifer Monitoring Program to observe trends in baseflow in Chevelon and Clear Creeks.

Surface-water discharge data were collected at three sites, two on Clear Creek and one on Chevelon Creek (fig. 4). These streamflow-gaging stations were discontinued and have not been monitored due to the lack of funding support since September 2007 for Clear Creek near Winslow, AZ (09399000), and Clear Creek below McHood Lake, near Winslow, AZ (09399100), and since December 2006 for Chevelon Creek near Winslow, AZ (09398000) (fig. 4; tables 2-11). Daily mean discharge values for the three streamflow-gaging stations for the period they operated can be accessed online (http://waterdata.usgs.gov/nwis/ $\mathrm{dv} /$ ?referred_module $=\mathrm{sw}$ ).

Baseflow in Chevelon Creek and Clear Creek and parts of the LCR are sustained by C-aquifer spring discharge. The majority of flow during non-baseflow conditions can be attributed to precipitation runoff either from winter and spring snowmelt or summer monsoonal activity. Daily mean discharge values were tabulated for three historical streamflow-gaging stations on Chevelon Creek and Clear Creek that were in service from 2005 to 2007 (tables 3-11).

Clear Creek near Winslow, AZ (09399000) and Chevelon Creek near Winslow, AZ (09398000) show discharge distribution indicative of a natural stream channel in the southwestern United States, with relatively low baseflow discharge values and higher discharge values during winter and spring snowmelt and during summer monsoon activity (tables 3-5, 9-11). Conversely, Clear Creek below McHood Lake, near Winslow, AZ (09399100) has discharge values that are more evenly distributed throughout the year as a result of anthropogenic modification of the stream channel in the form of a concrete and earthen dam forming a reservoir (tables 6-8). Most surface-water discharge upstream of the dam is captured; therefore, the streamflow gage at Clear Creek below McHood Lake, near Winslow, $\mathrm{AZ}$, predominantly is measuring discharge from $\mathrm{C}$-aquifer springs downstream of the dam structure.

\section{Baseflow Investigations}

Groundwater discharge from C-aquifer springs and seeps is the source of baseflow for Chevelon Creek, Clear Creek, and parts of the LCR. Baseflow (natural) is sustained flow of a stream by groundwater discharge in the absence of direct runoff (http://ga.water.usgs.gov/edu/dictionary.html\#B; accessed August 10,2012). Clear Creek and Chevelon Creek are tributaries to the LCR. The USGS conducted four separate baseflow investigations during 2005-11 along Clear Creek, Chevelon Creek, and the reach of the LCR between the confluences of the two tributaries. These investigations provided information about groundwater discharge and groundwater chemistry in selected reaches of these streams. Baseflow was measured at multiple locations along the streams in as short a time as possible, with the intent of developing a detailed snapshot regarding the locations and 


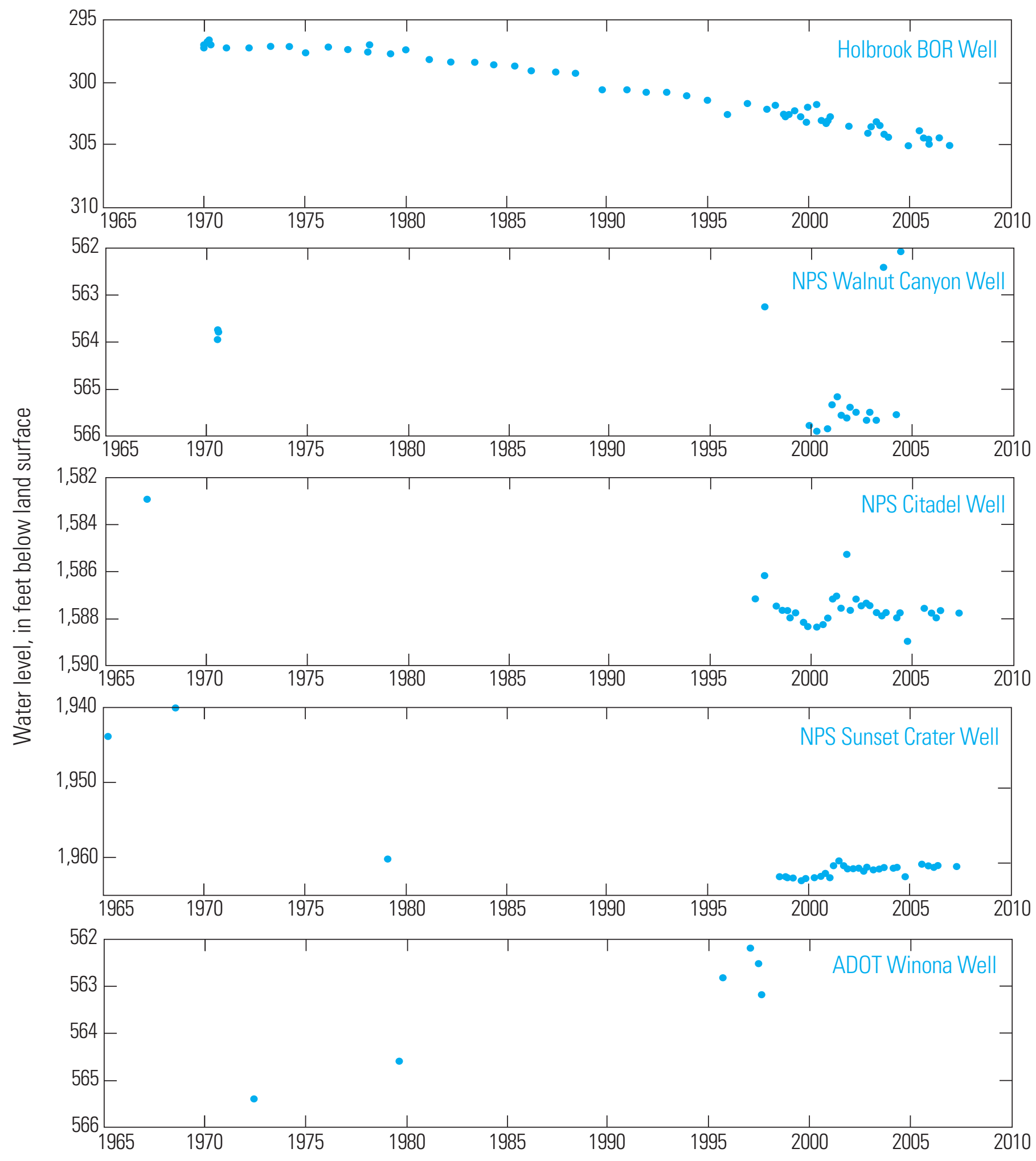

Figure 5. Measured water levels (1965-2010) in observation-well network, C aquifer, northeastern Arizona. 

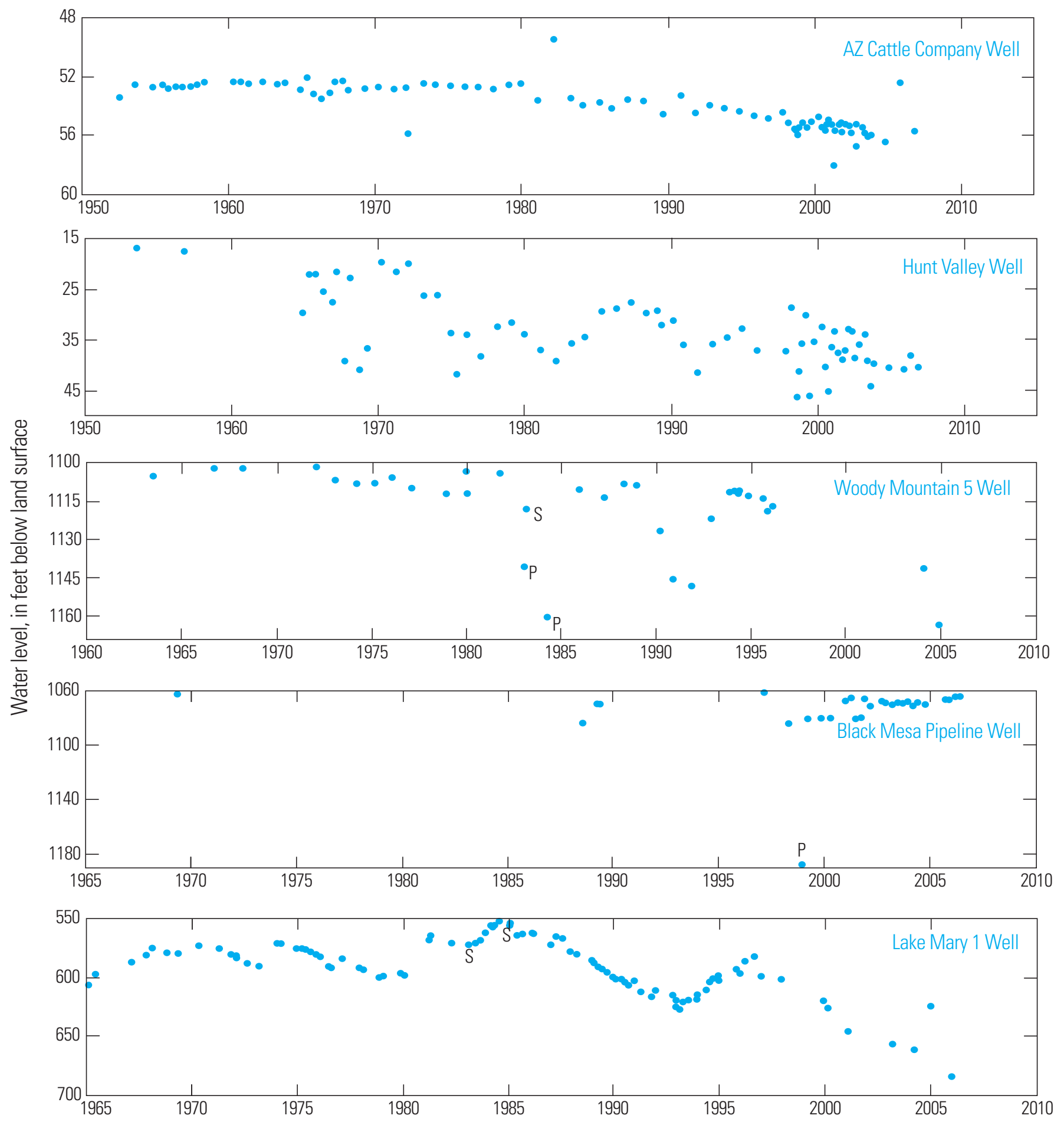

Figure 6. Measured water levels (1950, 1960, or 1965-2010) in observation-well network, C aquifer, northeastern Arizona. "S" indicates a nearby $\mathrm{C}$-aquifer well was being pumped during the measurement; " $\mathrm{P}$ " indicates the site well was being pumped. 


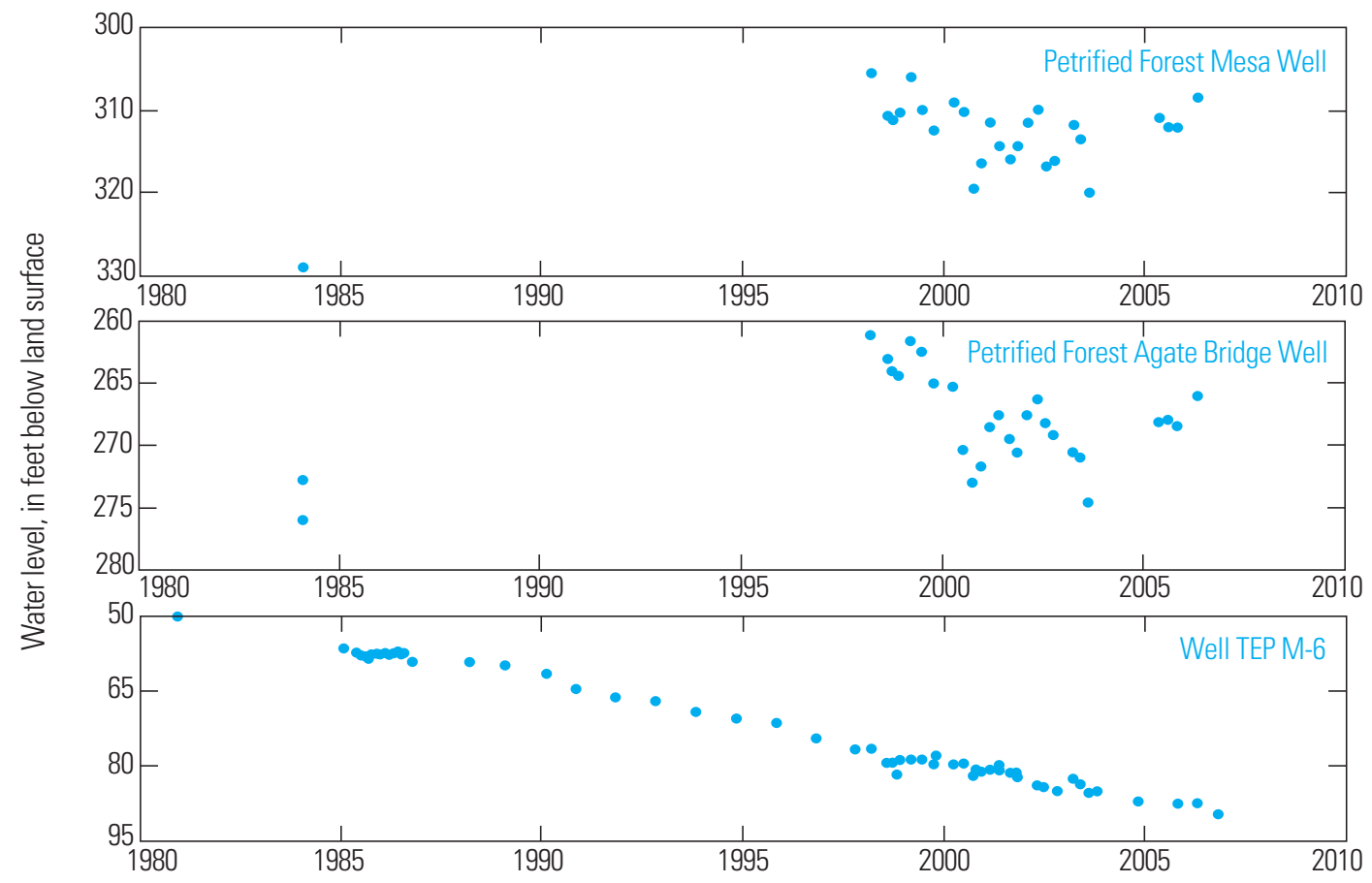

Figure 7. Measured water levels (1980-2010) in observation-well network, C aquifer, northeastern Arizona.

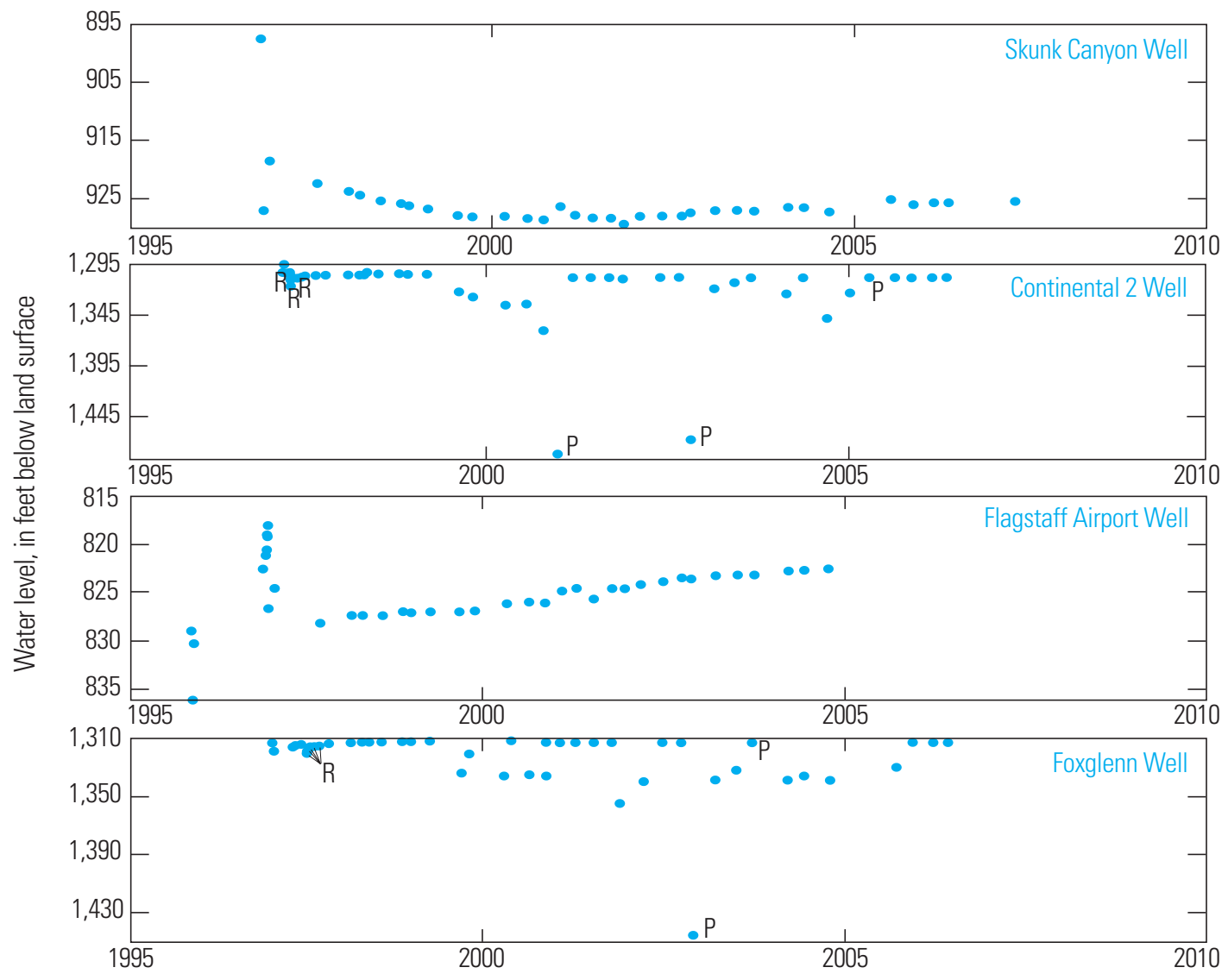

Figure 8. Measured water levels (1995-2010) in observation-well network, C aquifer, northeastern Arizona. " $P$ " indicates the site well was being pumped during the measurement; " $R$ " indicates the site well was recently pumped. 

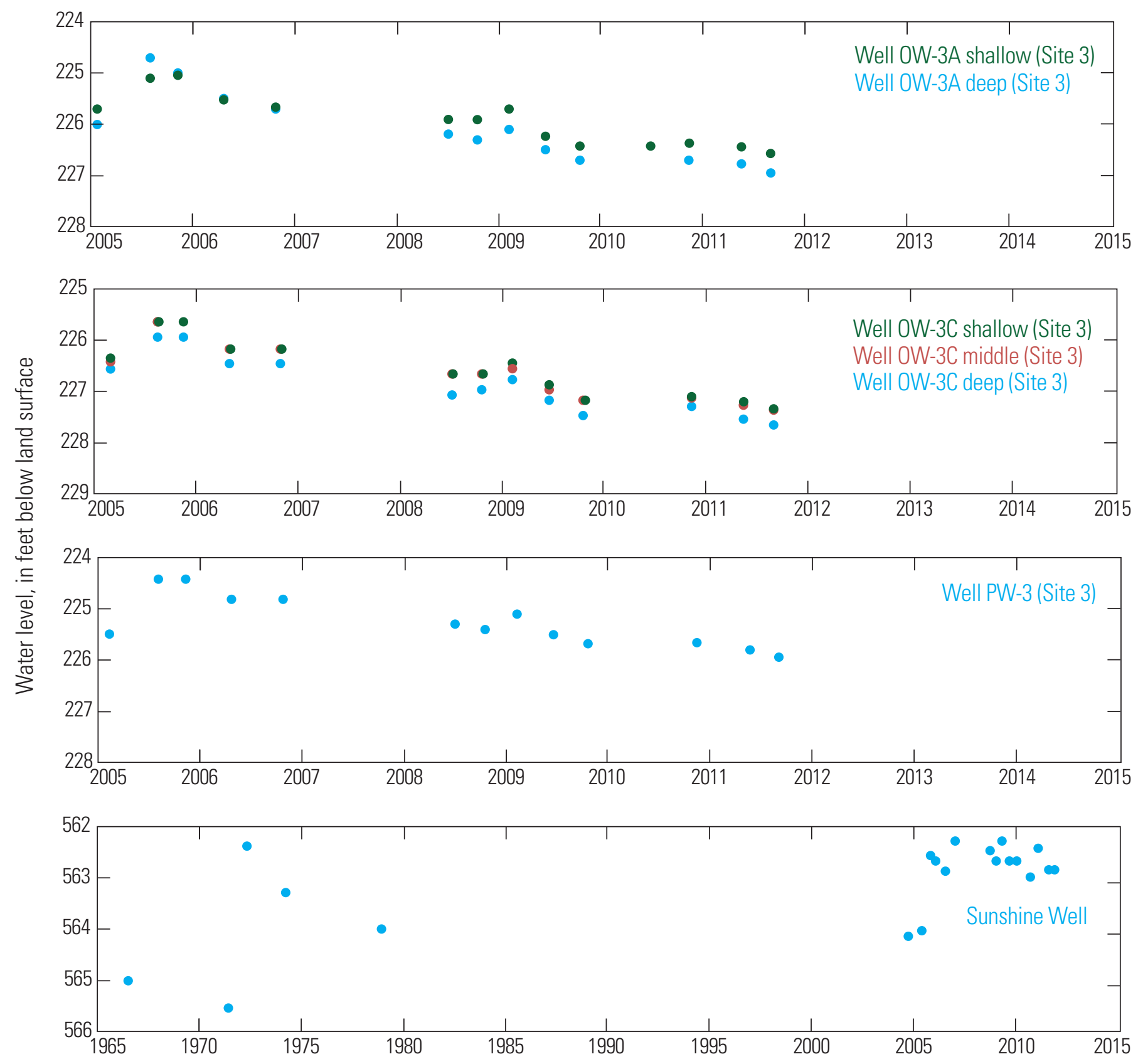

Figure 9. Measured water levels (1965 or 2005-2011) in observation-well network, C aquifer, northeastern Arizona. 

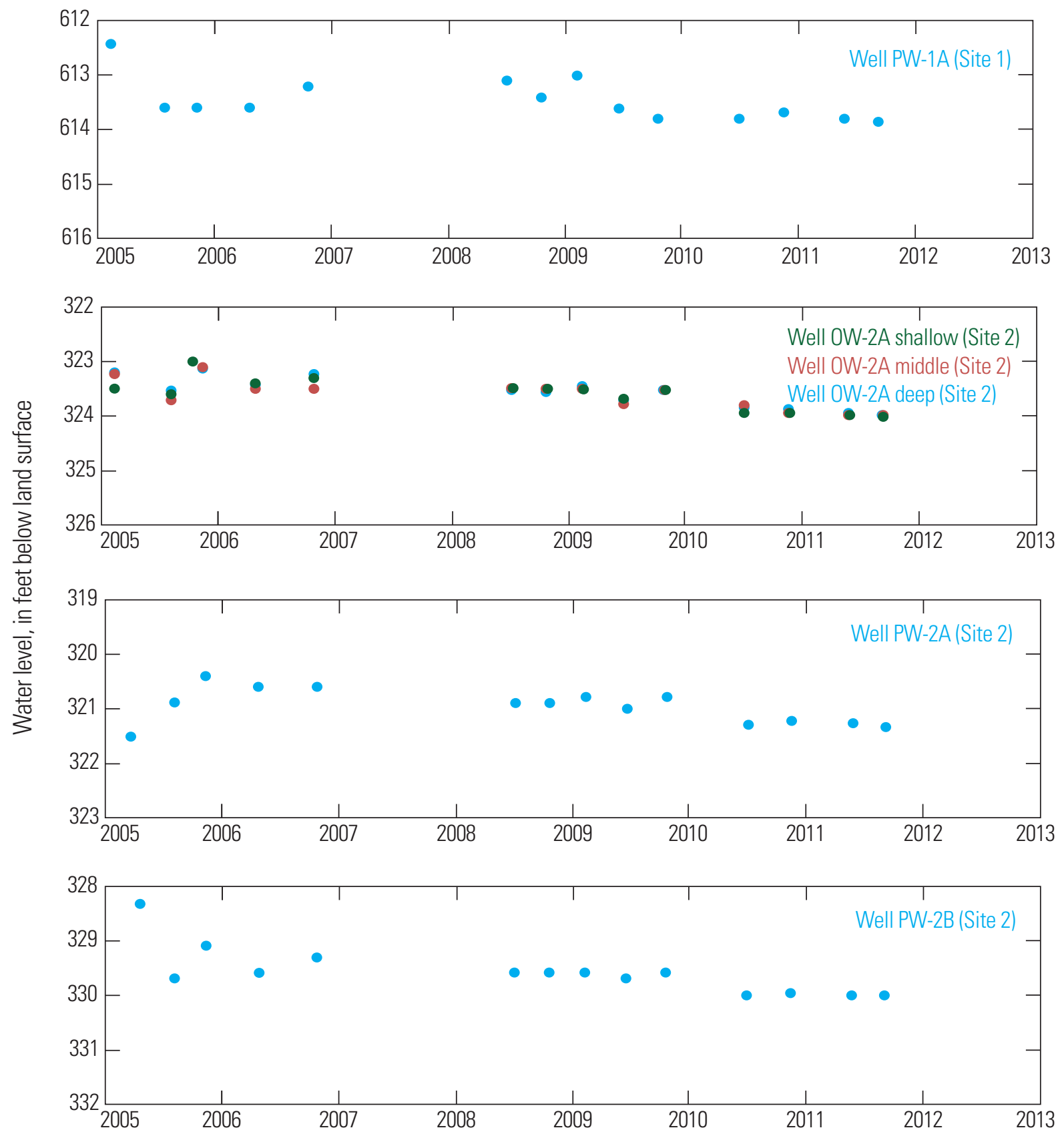

Figure 10. Measured water levels (2005-2011) in observation-well network, $C$ aquifer, northeastern Arizona. 
Table 2. Period of record and drainage areas for historic streamflow-gaging stations included in this study, northeastern Arizona.

\begin{tabular}{lccc}
\hline \multicolumn{1}{c}{ Station Name } & Station No. & $\begin{array}{c}\text { Period of } \\
\text { data collection }\end{array}$ & $\begin{array}{c}\text { Drainage area } \\
\text { (square miles) }\end{array}$ \\
\hline Clear Creek near Winslow, AZ & 09399000 & June 1906-Sept. 2007 & 621 \\
Clear Creek below McHood Lake, near Winslow, AZ & 09399100 & Sept. 2005-Sept. 2007 & Not known \\
Chevelon Creek near Winslow, AZ & 09398000 & Jan. 1906-Dec. 2006 & 785 \\
\hline
\end{tabular}

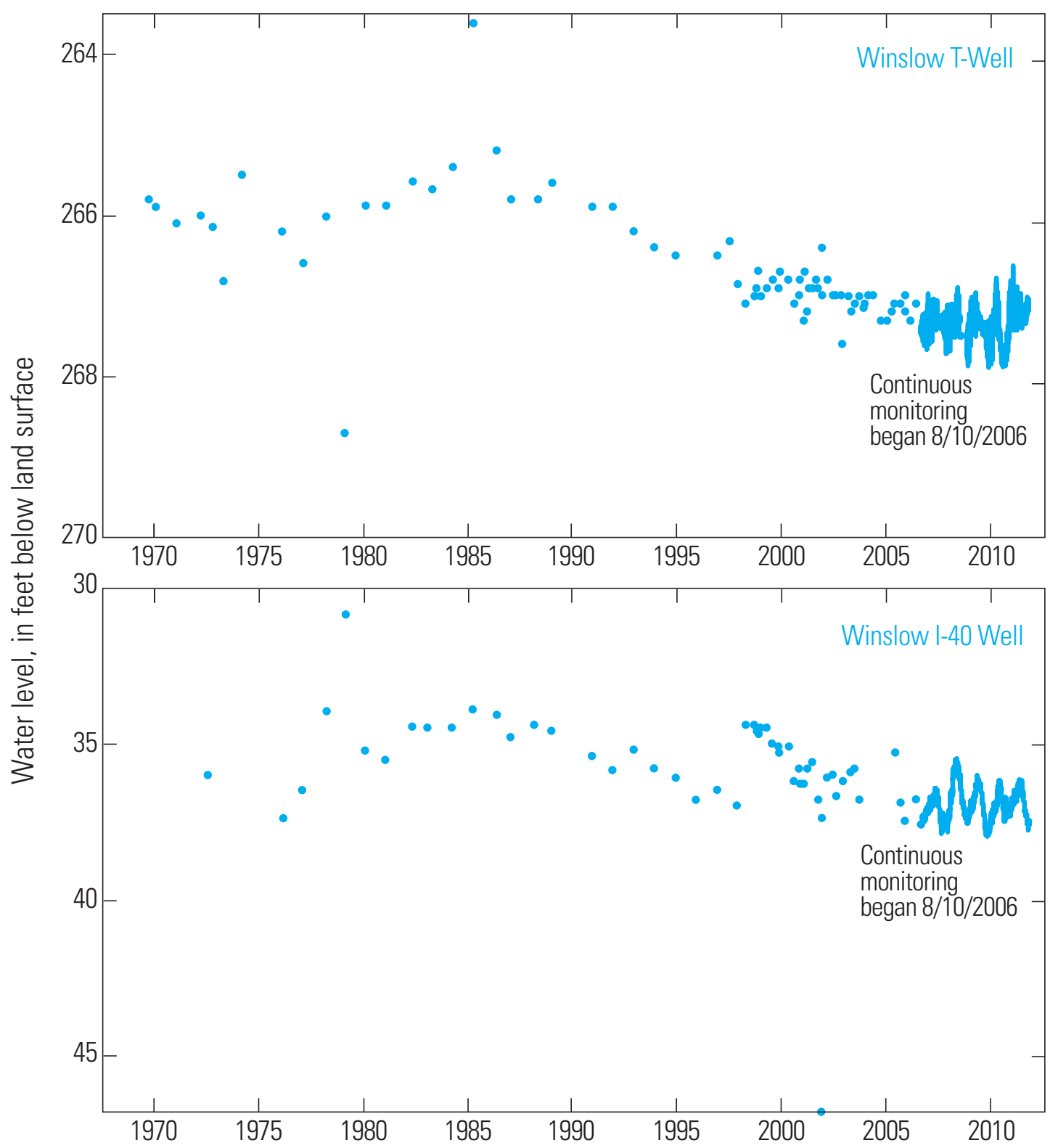

Figure 11. Measured and continuously recorded water levels (1965-2011) in observation-well network, $C$ aquifer, northeastern Arizona. See Figure 12 for a better view of the continuouslymonitored period. 

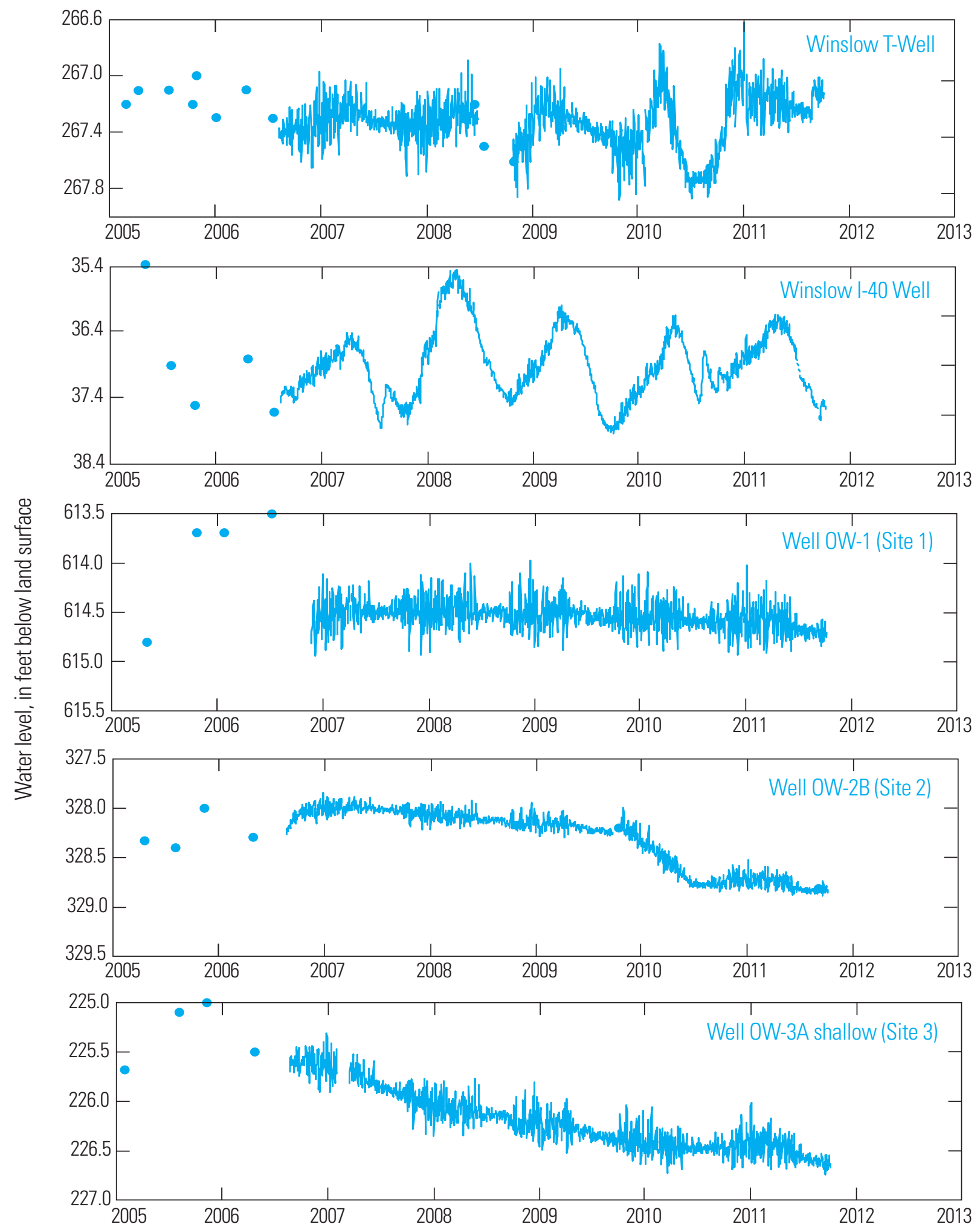

Figure 12. Measured and continuously recorded water levels (2005-2011) in observation-well network, $\mathrm{C}$ aquifer, northeastern Arizona. 
amounts of C-aquifer discharge entering and leaving the stream along its length. Each baseflow investigation provides physical and chemical information for one point in time that can be used to evaluate the effects of human-caused stress (groundwater withdrawal) or natural stress, such as climate change. Repeat baseflow investigations and continuous monitoring of baseflow at streamflow-gaging stations can provide long-term information on $\mathrm{C}$-aquifer baseflow trends.

The baseflow investigations were conducted during the summers of 2005, 2006, and 2008 and the winter of 2010. Water-quality field parameters $(\mathrm{pH}$, temperature, specific conductance, and dissolved oxygen percent saturation and concentration in milligrams per liter) and discharge were measured at each site to characterize physical and geochemical changes from near the headwaters of Chevelon Creek and Clear Creek to the confluence with the LCR. Seven sampling sites were established on the LCR, 11 sites along Chevelon Creek, and 14 sites along Clear Creek (table 12; fig. 13). Sites along Chevelon Creek and Clear Creek begin near the observed start of perennial flow, $11.6 \mathrm{mi}$ and $8.7 \mathrm{mi}$ upstream of the respective confluences with the LCR. Downstream sites were selected based on accessibility to the streams, and the presence of springs or manmade structures (dams, diversions, etc.). Discharge values for baseflow investigation sites are available online (http://waterdata.usgs. gov/nwis/measurements, accessed August 10, 2012) and in table 13. During the 2005 and 2006 baseflow investigations, water-chemistry samples were collected at selected sites and analyzed for major ions, nutrients, iron, boron, and arsenic. Water-chemistry data for $\mathrm{C}$-aquifer baseflow investigation sites are available online (http://nwis.waterdata.usgs.gov/usa/ nwis/qwdata).

Data collected during these baseflow investigations were tabulated by site number and date (table 13). Data are included from 15 sites along Chevelon Creek and the LCR near the confluence between Chevelon Creek and the LCR, and 16 sites along Clear Creek and the LCR near the confluence of Clear Creek and the LCR.

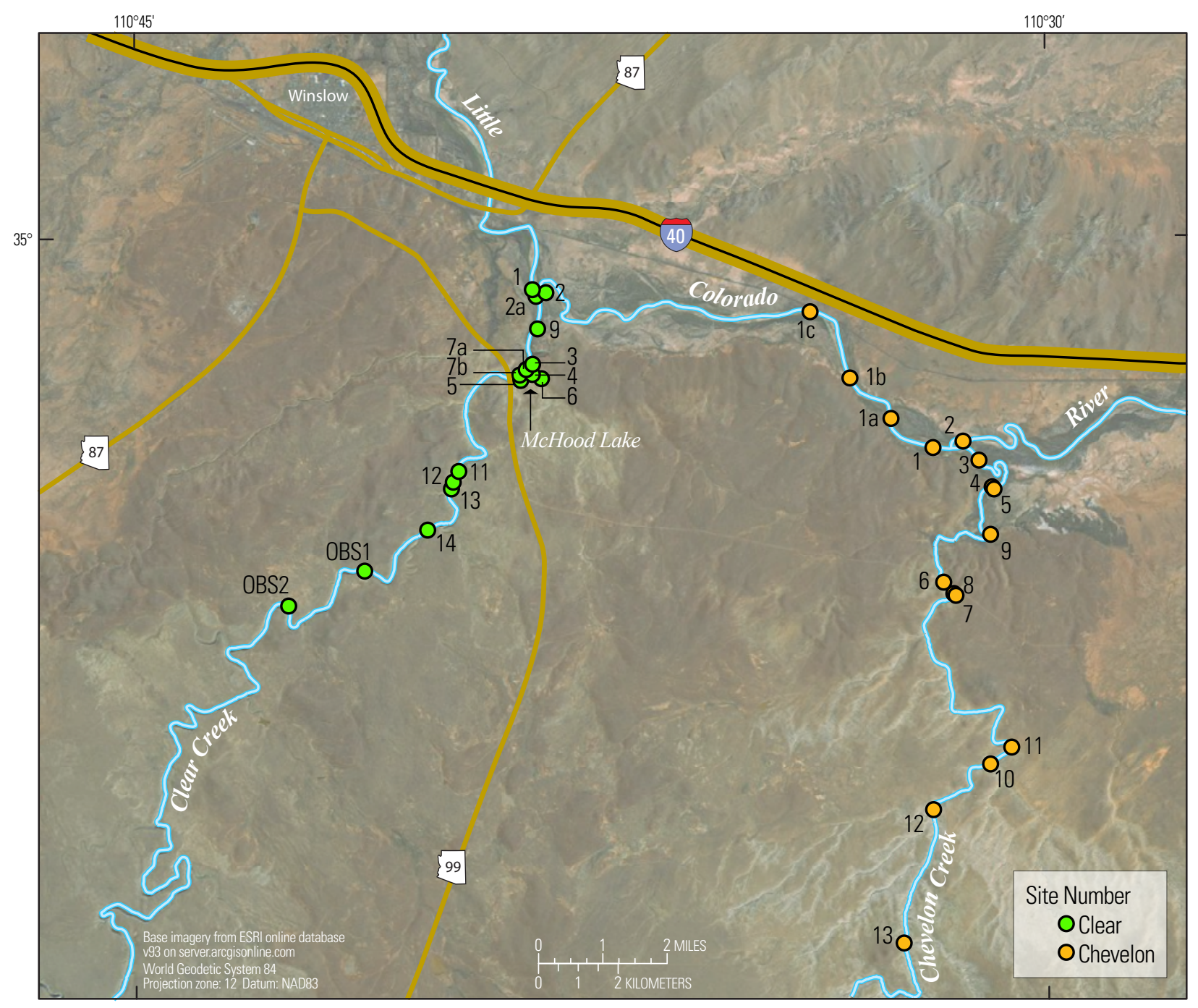

Figure 13. Locations of baseflow investigation sites (green and orange dots) included in this study, northeastern Arizona. 
Determining gaining and losing reaches of a springfed stream and how these characteristics seasonally and temporally change can be indicative of changing water levels within the source aquifer (Alley and others, 1999). A reach that was once gaining and begins to lose over time can indicate a lowering of the water table, and vice versa. Measured discharge data in cubic feet per second $\left(\mathrm{ft}^{3} / \mathrm{s}\right)$ from all four baseflow investigations were plotted to determine gaining and losing reaches along Clear and Chevelon Creeks (fig. 14).

Chevelon Creek is gaining in discharge from where perennial flow begins to approximately 8.5 mi upstream of the confluence with the LCR, and then loses discharge downstream, as flow is nearly zero at $3.5 \mathrm{mi}$ upstream of the confluence with the LCR because of backwater conditions created by a low-water dam at about $500 \mathrm{~m}$ upstream of the confluence. Beginning at the zero discharge point $3.5 \mathrm{mi}$ upstream of the confluence with the LCR to the confluence, Chevelon Creek shows gains in discharge, especially during the 2005-2010 baseflow investigations (fig. 14).

Clear Creek gains in discharge from its headwaters to about 3 mi upstream of its confluence with the LCR. Flow is near zero at about 1 mi upstream of the confluence with the LCR because of the damming of Clear Creek to form McHood Lake, southeast of Winslow, Arizona (fig. 14). A cluster of springs downstream of the dam structure provides gains in discharge along the reach from the dam to the confluence with the LCR.

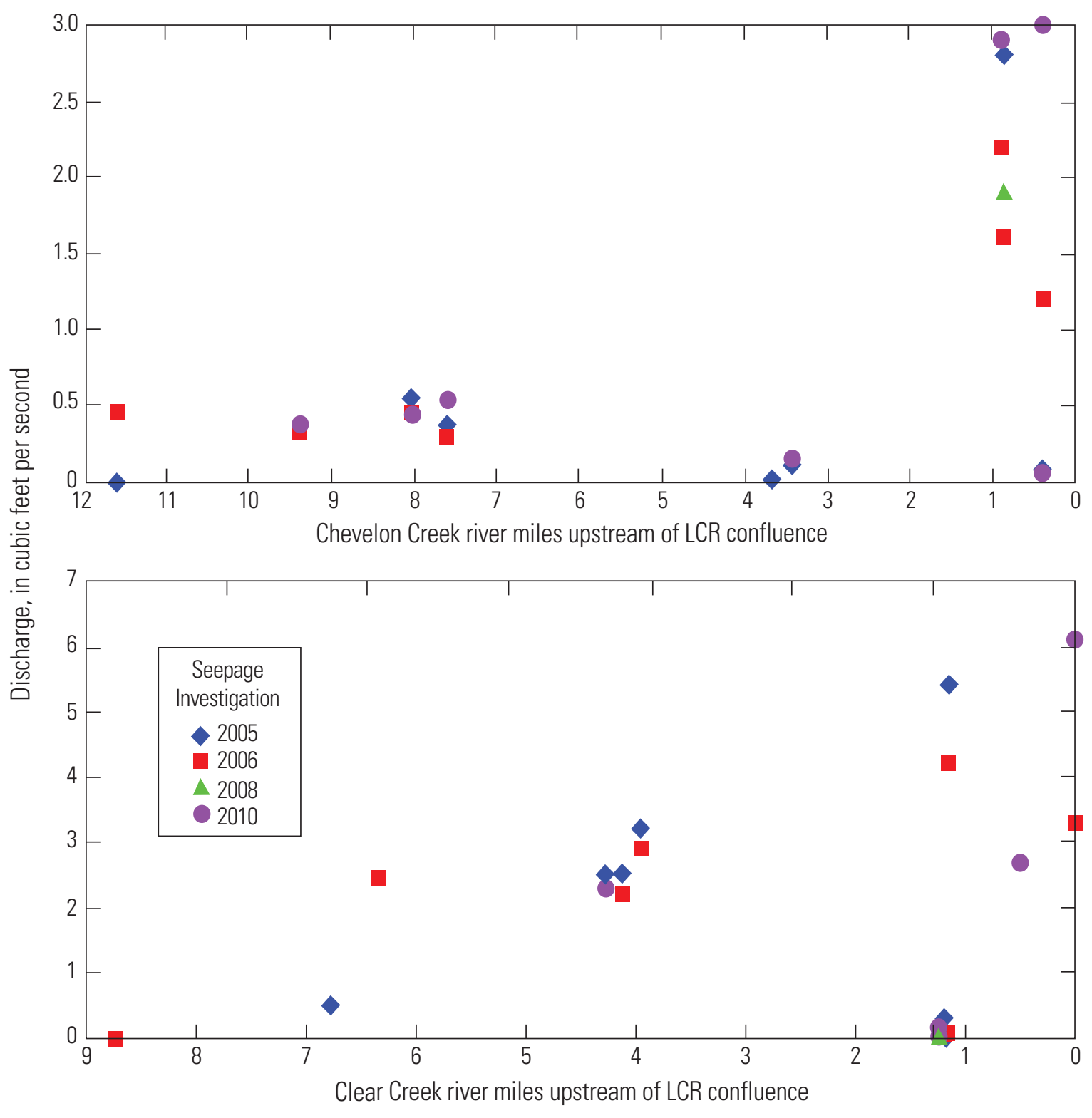

Figure 14. Discharge by river miles upstream of the confluence with the Little Colorado River (LCR) for baseflow investigation sites along Chevelon Creek and Clear Creek, northeastern Arizona. 


\section{Water Chemistry, 1933-2006}

Water-chemistry samples presented in this report were collected from 1933 to 2005 at 14 wells developed in the C aquifer (table 14). During 2005 and 2006, water samples were collected and analyzed from selected baseflowinvestigation sites (table 15). Quality assurance for the 2005 and 2006 baseflow sample collection was implemented by: (1) use of proper training of field personnel, (2) use of standard USGS field and laboratory protocols (U.S. Geological Survey, variously dated), (3) collection of four field sample blanks (two samples collected at spring sites during the 2006 baseflow investigations and two well samples collected directly from a hose bib on the well casing in 2001 and 2005), and (4) thorough review of the analytical results. All USGS scientists involved with this study have participated in the USGS National Field Quality Assurance Program, which requires participants to successfully determine $\mathrm{pH}$, specific conductance, and alkalinity of reference samples supplied by the USGS Branch of Quality Systems. Field personnel were trained in water-quality field methods by USGS personnel or through formal instruction at a USGS water-quality field-methods class.

\section{Well Water Chemistry, 1933-2005}

Periodically, samples from selected C-aquifer observation and supply wells are collected and analyzed for water chemistry. Field parameters are measured, and water samples are analyzed for major ions, nutrients, iron, boron, and arsenic. Water-quality data for selected wells from this study and other sites are accessible online (http://nwis. waterdata.usgs.gov/usa/nwis/qwdata).

Results of water-chemistry samples collected from 14 wells between 1933 and 2005 are shown in table 14 and also are available online at http://nwis.waterdata.usgs. gov/usa/nwis/qwdata. Specific conductance values ranged from $380 \mu \mathrm{S} / \mathrm{cm}$ at the NPS Walnut Canyon well to 5,870 $\mu \mathrm{S} / \mathrm{cm}$ at the Winslow I-40 well. The highest calcium concentration $(150 \mathrm{mg} / \mathrm{L})$ was at the Winslow I-40 well. The remaining wells had calcium concentrations ranging from $148 \mathrm{mg} / \mathrm{L}$ at NPS Sunset Crater Well to $41.1 \mathrm{mg} / \mathrm{L}$ at the Winslow T-Well. Sodium concentration was highest $(1,000 \mathrm{mg} / \mathrm{L})$ at the Winslow I-40 Well. The remaining wells had sodium concentrations ranging from $947 \mathrm{mg} / \mathrm{L}$ at the Winslow T-Well to $3.90 \mathrm{mg} / \mathrm{L}$ at the NPS Walnut Canyon well. Chloride concentration was highest $(1,500 \mathrm{mg} / \mathrm{L})$ at the Winslow I-40 Well. Chloride concentrations in the remaining wells ranged from $1,210 \mathrm{mg} / \mathrm{L}$ at the Winslow T-Well to $4.00 \mathrm{mg} / \mathrm{L}$ at the NPS Walnut Canyon. Sulfate concentration was highest $(617 \mathrm{mg} / \mathrm{L})$ at the Winslow T-Well. Sulfate concentrations in the remaining wells ranged from $386 \mathrm{mg} / \mathrm{L}$ at Well OW-1 to $1.90 \mathrm{mg} / \mathrm{L}$ at the
NPS Walnut Canyon well. Iron concentration was highest $(3,000 \mu \mathrm{g} / \mathrm{L})$ at Well TEP M-6. Iron concentrations in the remaining wells ranged from $794 \mu \mathrm{g} / \mathrm{L}$ at Well OW-1 to not detected at the NPS Walnut Canyon well. Total dissolved solids (TDS) concentration was highest $(1,610 \mathrm{mg} / \mathrm{L})$ at the Tucker Mesa well. Total dissolved solids concentrations for the remaining wells ranged from $855 \mathrm{mg} / \mathrm{L}$ at well $\mathrm{PW}-1 \mathrm{~A}$ to $203 \mathrm{mg} / \mathrm{L}$ at the NPS Walnut Canyon well.

Chemical constituents from the 14 wells were compared to the U.S. Environmental Protection Agency (USEPA) primary and secondary drinking water standards (U.S. Environmental Protection Agency, 2009). Maximum contaminant levels (MCLs), which are the primary regulations, are legally enforceable standards that apply to public water systems. MCLs protect drinking-water quality by limiting the levels of specific contaminants that adversely can affect public health. Secondary maximum contaminant levels (SMCLs) provide guidelines for the control of contaminants that may cause cosmetic effects (such as skin or tooth discoloration) or aesthetic effects (such as taste, odor, or color) in drinking water. The USEPA recommends compliance with SMCLs for public water systems; however, compliance is not enforced. None of the water samples analyzed exceeded the USEPA MCL standards, but several samples exceeded the USEPA SMCL standards for chloride, fluoride, sulfate, iron, and total dissolved solids (table 14). The SMCL for chloride $(250 \mathrm{mg} / \mathrm{L})$ was exceeded by samples from three wells: the Winslow T-Well, the Winslow I-40 Well, and Tucker Mesa. The SMCL for fluoride $(2.0 \mathrm{mg} / \mathrm{L})$ was exceeded by two water samples from Well TEP M-6, both samples were collected on the same day in 1985. The SMCL for sulfate $(250 \mathrm{mg} / \mathrm{L})$ was exceeded by four samples from the Winslow T-Well collected in 1969; four samples from the Sunshine Well collected in 1953, 1978, and 2005; four samples from Well PW-3 collected in 2005; three samples from Well OW-1 collected in 2005; four samples from Well PW-1A; four samples from Well PW-2B collected in 2005; and two samples from Well OW-2B collected in 2005 . The SMCL for iron $(300 \mu \mathrm{g} / \mathrm{L})$ was exceeded by two samples from Well TEP M-6 collected in 1985; one sample from Well PW-3 collected in 2005; one sample from Well OW-1 collected in 2005; two samples from Well PW-1A collected in 2005; and two samples from Well OW-2B collected in 2005. The SMCL for total dissolved solids $(500 \mathrm{mg} / \mathrm{L})$ was exceeded by seven wells: one sample from the Tucker Mesa well collected in 2006; two samples from the Sunshine Well collected in 2005; three samples from well PW-3 collected in 2005; three samples from well OW-1 collected in 2005; three samples from well PW-1A collected in 2005; three samples from well PW-2B collected in 2005; and two samples from well OW-2B collected in 2005 . 


\section{Baseflow Investigation Water Chemistry, 2005-10}

Water samples were collected and analyzed for water chemistry (major ions, nutrients, iron, boron, and arsenic) and field parameters parameters $(\mathrm{pH}$, temperature, specific conductance, and dissolved oxygen percent saturation and concentration in milligrams per liter) at 5 sites during the 2005 baseflow investigation and 10 sites during the 2006 baseflow investigation (table 15). The 2005 samples were taken at three
Chevelon Creek sites and two Clear Creek sites. Sampling for the 2006 baseflow investigation took place at six Chevelon Creek sites and four Clear Creek sites.

Water-chemistry samples from sites that were sampled during both the 2005 and the 2006 baseflow investigations showed similar physical and chemical properties (table 15). Specific conductance for Chevelon Creek sites ranged from $806 \mu \mathrm{S} / \mathrm{cm}$ at Chevelon Site 11 in 2005 to $5,090 \mu \mathrm{S} / \mathrm{cm}$ at the Chevelon Site 1b in 2006 (table 15). Chloride concentrations

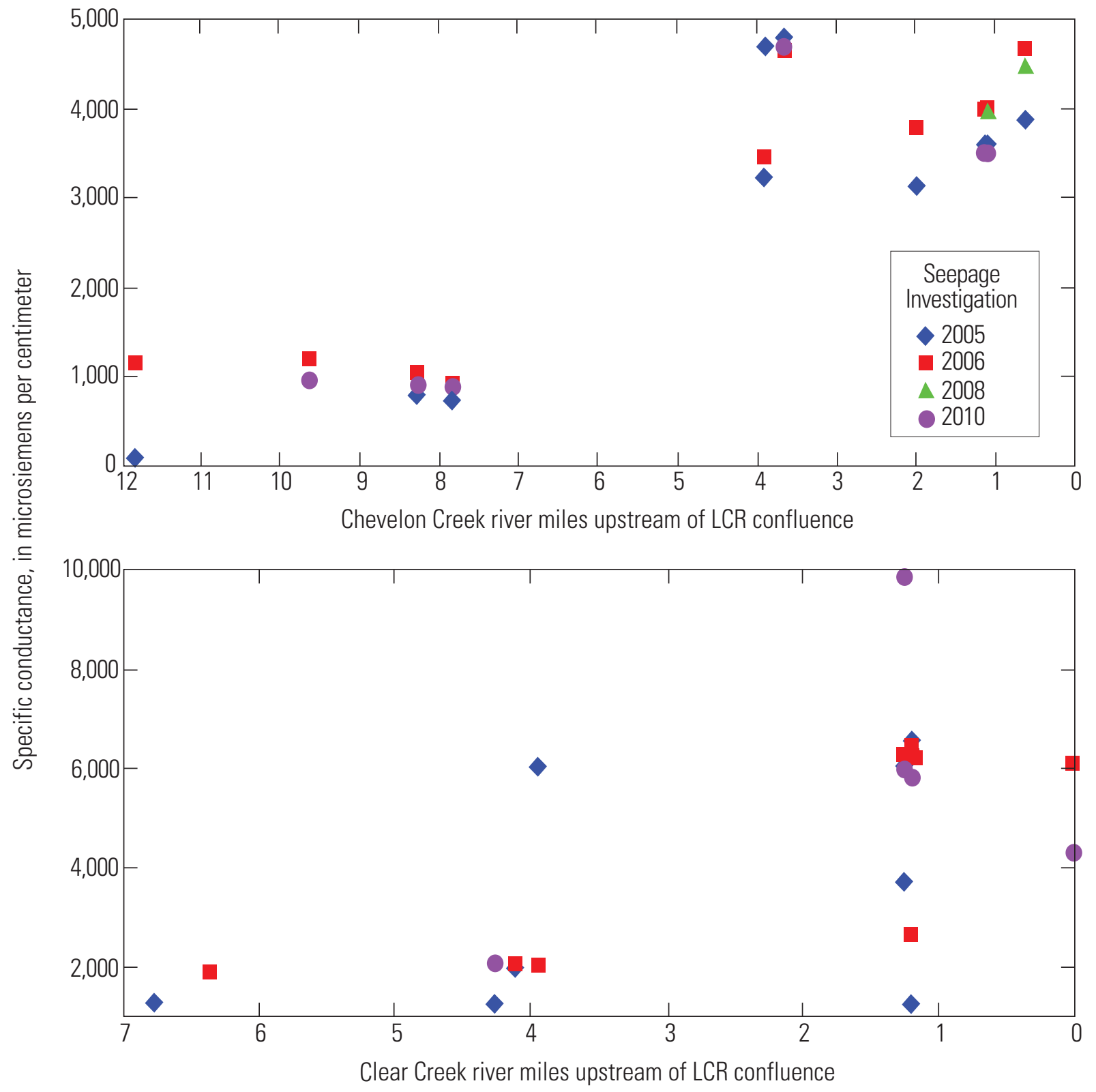

Figure 15. Specific conductance by river miles upstream of the confluence with the Little Colorado River (LCR) for baseflow investigation sites along Chevelon Creek and Clear Creek, northeastern Arizona. 
for Chevelon Creek sites ranged from $94.2 \mathrm{mg} / \mathrm{L}$ at Chevelon Site 11 in 2005 to $1,400 \mathrm{mg} / \mathrm{L}$ at Chevelon Site $1 \mathrm{~b}$ in 2006, whereas dissolved-solids concentrations ranged from $488 \mathrm{mg} / \mathrm{L}$ at Chevelon Site 11 in 2005 to 2,910 mg/L at Chevelon Site $1 \mathrm{~b}$ in 2006 (table 15). Specific conductance for Clear Creek sites ranged from $1,980 \mu \mathrm{S} \mathrm{cm}$ at Clear Site 14 in 2006 to $6,300 \mu \mathrm{S} / \mathrm{cm}$ at Clear Site 3 in 2005 (table 15). Chloride concentrations for Clear Creek sites ranged from $498 \mathrm{mg} / \mathrm{L}$ at Clear Site 14 in 2006 to $1,750 \mathrm{mg} / \mathrm{L}$ at Clear Site 6 in 2005 and 2006, whereas dissolved-solids concentrations ranged from $1,070 \mathrm{mg} / \mathrm{L}$ at Clear Site 14 in 2006 to 3,610 mg/L at Clear Site 6 in 2006 (table 15).

Of the field parameters measured, specific conductance showed the most change in values from near the headwaters to the confluence with the LCR for Chevelon and Clear Creeks during all four baseflow investigations (table 13; fig. 15). There is an increase in specific conductance of about 4,500 $\mu \mathrm{S} / \mathrm{cm}$ from near the headwaters of Chevelon Creek to the confluence with the LCR. This increase may be attributed to either the introduction of highly conductive groundwater discharge (increase in specific conductance initially occurs at spring sites, Chevelon Site 6 and Chevelon Site 8) along the stream and/or surface-water interaction with local geology of a high evaporate content. Clear Creek shows a less consistent pattern of increase in specific conductance, probably due to the lack of sites, but still exhibits changes on the order of $5,000 \mu \mathrm{S} / \mathrm{cm}$ within a few river miles (fig. 15).

\section{Field Parameters}

In 2005, data were collected from July 6 to 7 . This investigation included 13 sites along Chevelon Creek and the LCR near the confluence, and 12 sites along Clear Creek and the LCR near the confluence (table 12). Specific conductance values for Chevelon Creek sites ranged from $115 \mu \mathrm{S} / \mathrm{cm}$ at Chevelon Site 13 to $4,800 \mu \mathrm{S} / \mathrm{cm}$ at Chevelon Site 6 (table 13). pH values for Chevelon Creek sites ranged from 6.9 at Site 6 to 9.2 at Chevelon Site 13 (table 13). Dissolved-oxygen concentration for Chevelon Creek sites ranged from $3.0 \mathrm{mg} / \mathrm{L}$ at Chevelon Site 6 to $9.1 \mathrm{mg} / \mathrm{L}$ at Site 3 (table 13). Specific conductance values for Clear Creek sites ranged from $1,190 \mu \mathrm{S} / \mathrm{cm}$ at Clear Site 7 a to $7,120 \mu \mathrm{S} / \mathrm{cm}$ at Clear Site 2 (table 13). $\mathrm{pH}$ values for Clear Creek sites ranged from 7.2 at Clear Site 5 and Clear Site 6 to 9.2 at Site Clear Site 7b (table 13). Dissolved-oxygen concentration for Clear Creek sites ranged from $1.5 \mathrm{mg} / \mathrm{L}$ at Clear Site 5 to $9.5 \mathrm{mg} / \mathrm{L}$ at Clear Site 12 (table 13).

\section{Field Parameters}

In 2006, data were collected from June 22 to 23 . This investigation included 15 sites along Chevelon Creek and the LCR near the confluence, and 11 sites along Clear Creek and the LCR near the confluence (table 12). Specific conductance values for Chevelon Creek sites ranged from $938 \mu \mathrm{S} / \mathrm{cm}$ at Chevelon Site 11 to $5,380 \mu \mathrm{S} / \mathrm{cm}$ at Chevelon Site 1c (table 13). pH values for Chevelon Creek sites ranged from 7.1 at Chevelon Site 6 to 8.9 at Chevelon Site 4 (table 13). Dissolved-oxygen concentration for Chevelon Creek sites ranged from $1.6 \mathrm{mg} / \mathrm{L}$ at Chevelon Site 6 to $8.9 \mathrm{mg} / \mathrm{L}$ at Chevelon Site 3 (table 13). Specific conductance values for Clear Creek sites ranged from $1,980 \mu \mathrm{S} / \mathrm{cm}$ at Clear Site 14 to $6,390 \mu \mathrm{S} / \mathrm{cm}$ at Clear Site 6 (table 13). $\mathrm{pH}$ values for Clear Creek sites ranged from 7.4 at Clear Sites 4 , 5, and 6 to 8.8 at Clear Site 7a (table 13). Dissolved-oxygen concentration for Clear Creek sites ranged from $1.5 \mathrm{mg} / \mathrm{L}$ at Site 5 to $8.7 \mathrm{mg} / \mathrm{L}$ at Site 12 (table 13).

\section{Field Parameters}

In 2008, data were collected from June 24 to 25 . This investigation included six sites along Chevelon Creek and the LCR near the confluence, and three sites along Clear Creek and the LCR near the confluence (table 12). Specific conductance values for Chevelon Creek sites ranged from 3,960 $\mu \mathrm{S} / \mathrm{cm}$ at Chevelon Site 4 to $5,510 \mu \mathrm{S} / \mathrm{cm}$ at Chevelon Site 1c (table 13). pH values for Chevelon Creek sites ranged from 8.3 at Chevelon Site 3 to 8.5 at Chevelon Sites $1 \mathrm{~b}$ and 1c (table 13). Dissolved-oxygen concentration for Chevelon Creek sites ranged from $5.9 \mathrm{mg} / \mathrm{L}$ at Chevelon Site 4 to $7.1 \mathrm{mg} / \mathrm{L}$ at Chevelon Sites 1 and 2 (table1 3). Field parameters were not recorded for Clear Creek sites in 2008.

\section{Field Parameters}

In 2010, data were collected from December 1 to 2. This was the first winter baseflow investigation conducted. Winter data values can be compared to data from summer investigations to analyze seasonal variation in water quality and quantity for springs discharging from the $\mathrm{C}$ aquifer. Winter baseflow is less affected by evapotranspiration and runoff associated with monsoon activity; however, runoff conditions were not present during the 2005, 2006, and 2008 baseflow investigations. This investigation included 11 sites along Chevelon Creek and the LCR near the confluence and 8 sites along Clear Creek and the LCR near the confluence (table 12). Specific conductance values for Chevelon Creek sites ranged from $920 \mu \mathrm{S} / \mathrm{cm}$ at Chevelon Site 10 to 4,680 $\mu \mathrm{S} / \mathrm{cm}$ at Chevelon Site 6 (table 13). pH values for Chevelon Creek sites ranged from 7.8 at sites Chevelon Sites 5 and 1a to 8.6 at Chevelon Site 4 (table 13). Dissolved-oxygen concentration for Chevelon Creek sites ranged from $4.0 \mathrm{mg} / \mathrm{L}$ at Chevelon Site 6 to $11.3 \mathrm{mg} / \mathrm{L}$ at Chevelon Site 11 (table 13). Specific conductance values for Clear Creek sites ranged from 2,030 $\mu \mathrm{S} / \mathrm{cm}$ at Clear Site 13 to $9,840 \mu \mathrm{S} / \mathrm{cm}$ at Clear Site $7 \mathrm{~b}$ (table 13). $\mathrm{pH}$ values for Clear Creek sites ranged from 7.0 at Clear Site $7 \mathrm{~b}$ to 8.4 at Clear Site 13. Dissolved-oxygen concentration for Clear Creek sites ranged from $1.4 \mathrm{mg} / \mathrm{L}$ at Clear Site 5 to $11.2 \mathrm{mg} / \mathrm{L}$ at Clear Site 13 (table 13). 


\section{Summary}

The $\mathrm{C}$ aquifer is a regionally extensive aquifer supplying water for municipal, agricultural, and industrial use in northeastern Arizona, northwestern New Mexico, and southeastern Utah. This report presents data from an ongoing study by the U.S. Geological Survey (USGS) in cooperation with the Bureau of Indian Affairs to monitor water quality and quantity within the $\mathrm{C}$ aquifer along Interstate 40 (I-40) corridor from near Holbrook to Flagstaff. Data presented includes: (1) water-level data from 35 wells completed in C aquifer, (2) surface-water discharge data from 3 discontinued streamflow-gage sites on Chevelon and Clear Creeks, (3) water chemistry from selected well sites and baseflow investigation sites, and (4) water-quality parameters and discharge measurements from the four baseflow investigations conducted on reaches of Clear and Chevelon Creeks, and a reach of the Little Colorado River (LCR). Data from 2005 to the end of water year 2011 were the focus of this report, but water-level data from the 1950s and 1960 s and water-chemistry data dating to the 1930s also were reported.

Water-level data for the $\mathrm{C}$ aquifer are monitored to establish baseline water-level information prior to potential effects of future development on the aquifer. Depth-towater increased around pumping centers, whereas little to no change in water level was observed in more remote area wells during 2005-2011. Change in water level as a percentage of the initial water-level measurement for 15 wells ranged from about -0.2 to about -0.5 percent. For historical water-level data, changes in water levels were greatest around pumping centers, as indicated by a -97.0 feet (ft) (percentage difference of -16.5 percent) change over the period of record (1962-2005) for the Lake Mary 1 Well near Flagstaff, Arizona. Of the five continuously monitored wells, water levels for the end of water year 2011 ranged from $37.6 \mathrm{ft}$ below land surface at the Winslow I-40 Well to $614.8 \mathrm{ft}$ below land surface at Well OW-1. The greatest change in depth-to-water for the period of 2005-11 ( $-2.5 \mathrm{ft})$ was recorded at the Winslow I-40 Well. The greatest positive change in depth-to-water for the period of 2005-11 (0.2 ft) occurred at Well OW-1.

Four separate baseflow investigations have been conducted (the summers of 2005, 2006, and 2008, and winter 2010) on Chevelon Creek, Clear Creek, and the LCR. Field parameters and stream discharge were measured at 15 Chevelon Creek sites and 15 Clear Creek sites to determine gaining and losing reaches and to assess the quality and quantity of water discharging from $\mathrm{C}$ aquifer. There was a 4,500 microsiemens per centimeter $(\mu \mathrm{S} / \mathrm{cm})$ increase in specific conductance from the headwaters of Chevelon Creek to the confluence with the LCR. This increase may be attributed to introduction of highly conductive groundwater via spring discharge along the stream, or surface-water interaction with country rock of a high evaporate content. Clear Creek shows a less consistent pattern of increase in specific conductance, but still exhibits changes on the order of $5,000 \mu \mathrm{S} / \mathrm{cm}$ within a few river miles.

Water-chemistry analyses for 14 wells within the $\mathrm{C}$ aquifer monitoring well network are available beginning in 1933. Since 1933, specific conductance values have ranged from $4,740 \mu \mathrm{S} / \mathrm{cm}$ at the Winslow T-Well, to $380 \mu \mathrm{S} / \mathrm{cm}$ at NPS Walnut Canyon. Total dissolved solids concentration was highest $(1,610 \mathrm{mg} / \mathrm{L})$ at the Tucker Mesa well. Total dissolved solids concentrations for the remaining wells ranged from $855 \mathrm{mg} / \mathrm{L}$ at Well $\mathrm{PW}-1 \mathrm{~A}$ to $203 \mathrm{mg} / \mathrm{L}$ at the NPS Walnut Canyon well. None of the samples analyzed exceeded the U.S. Environmental Protection Agency (USEPA) maximum contaminant levels standards, but several samples exceeded the USEPA secondary maximum contaminant levels standards for chloride, fluoride, and sulfate. Water samples also were collected and analyzed for water chemistry (major ions, nutrients, iron, boron, and arsenic) at 5 sites during the 2005 baseflow investigation and 10 sites during the 2006 baseflow investigation. Samples from sites that were sampled during the 2005 and the 2006 baseflow investigations showed similar physical and chemical signatures.

Tables 3-14 to follow. 
Table 3. Daily mean discharge for Clear Creek near Winslow, AZ (09399000), calendar year 2005.

[e, estimated; CFSM, cubic feet per square mile; dashes indicate no data]

\begin{tabular}{|c|c|c|c|c|c|c|c|c|c|c|c|c|}
\hline \multicolumn{13}{|c|}{ Discharge, in cubic feet per second, calendar year 2005-daily mean values } \\
\hline DAY & JAN & FEB & MAR & APR & MAY & JUN & JUL & AUG & SEP & OCT & NOV & DEC \\
\hline 1 & --- & --- & --- & --- & --- & --- & --- & 0.00 & 0.00 & 1.5 & 0.10 & 0.51 \\
\hline 2 & --- & --- & --- & --- & --- & --- & --- & 0.00 & 0.00 & 1.6 & 0.10 & 0.40 \\
\hline 3 & --- & --- & --- & --- & --- & --- & --- & 0.00 & 0.00 & 1.5 & 0.08 & 0.43 \\
\hline 4 & --- & --- & --- & --- & --- & --- & --- & 0.00 & 0.00 & 0.70 & 0.10 & 0.45 \\
\hline 5 & --- & --- & --- & --- & --- & --- & --- & 0.00 & 0.00 & 0.13 & 0.10 & 0.45 \\
\hline 6 & --- & --- & --- & --- & --- & --- & --- & 0.00 & 0.00 & 0.00 & 0.11 & 0.40 \\
\hline 7 & --- & --- & --- & --- & --- & --- & --- & 0.00 & 0.00 & 0.00 & 0.15 & 0.52 \\
\hline 8 & --- & --- & --- & --- & --- & --- & --- & 0.00 & 0.00 & 0.00 & 0.19 & 0.53 \\
\hline 9 & --- & --- & --- & --- & --- & --- & --- & 0.00 & 0.00 & 0.00 & 0.21 & 0.55 \\
\hline 10 & --- & --- & --- & --- & --- & --- & --- & 7.4 & 0.00 & 0.00 & 0.26 & 0.57 \\
\hline 11 & --- & --- & --- & --- & --- & --- & --- & 8.3 & 0.00 & 0.00 & 0.27 & 0.53 \\
\hline 12 & --- & --- & --- & --- & --- & --- & --- & 2.6 & 0.00 & 0.00 & 0.31 & 0.53 \\
\hline 13 & --- & --- & --- & --- & --- & --- & --- & 1.4 & 0.00 & 0.00 & 0.31 & 0.53 \\
\hline 14 & --- & --- & --- & --- & --- & --- & --- & 0.74 & 0.00 & 0.00 & 0.32 & 0.54 \\
\hline 15 & --- & --- & --- & --- & --- & --- & --- & 0.34 & 0.00 & 0.00 & 0.33 & 0.53 \\
\hline 16 & --- & --- & --- & --- & --- & --- & --- & 0.08 & 0.00 & 0.00 & 0.31 & 0.57 \\
\hline 17 & --- & --- & --- & --- & --- & --- & --- & 0.00 & 0.00 & 0.00 & 0.31 & 0.60 \\
\hline 18 & --- & --- & --- & --- & --- & --- & --- & 0.00 & 0.00 & 0.00 & 0.33 & 0.62 \\
\hline 19 & --- & --- & --- & --- & --- & --- & --- & 0.11 & 0.00 & 0.00 & 0.35 & 0.62 \\
\hline 20 & --- & --- & --- & --- & --- & --- & --- & 0.15 & 0.00 & 0.00 & 0.36 & 0.68 \\
\hline 21 & --- & --- & --- & --- & --- & --- & 0.00 & 0.00 & 0.00 & 0.00 & 0.41 & 0.76 \\
\hline 22 & --- & --- & --- & --- & --- & --- & 0.00 & 0.00 & 0.00 & 0.00 & 0.48 & 0.83 \\
\hline 23 & --- & --- & --- & --- & --- & --- & 0.00 & 0.00 & 0.00 & 0.00 & 0.51 & 0.83 \\
\hline 24 & --- & --- & --- & --- & --- & --- & 0.00 & 0.00 & 0.00 & 0.00 & 0.59 & 0.77 \\
\hline 25 & --- & --- & --- & --- & --- & --- & 0.00 & 0.00 & 0.00 & 0.00 & 0.61 & 0.76 \\
\hline 26 & --- & --- & --- & --- & --- & --- & 0.00 & 0.00 & 0.00 & 0.00 & 0.58 & 0.71 \\
\hline 27 & --- & --- & --- & --- & --- & --- & 0.00 & 0.00 & 0.03 & 0.00 & 0.55 & 0.70 \\
\hline 28 & --- & --- & --- & --- & --- & --- & 0.00 & 0.00 & 0.38 & 0.00 & 0.52 & 0.69 \\
\hline 29 & --- & --- & --- & --- & --- & --- & 0.00 & 0.00 & 0.78 & 0.01 & 0.51 & 0.74 \\
\hline 30 & --- & --- & --- & -- & --- & --- & 0.00 & 0.00 & 1.1 & 0.05 & 0.53 & 0.75 \\
\hline 31 & --- & --- & --- & --- & --- & --- & 0.00 & 0.00 & --- & 0.08 & --- & 0.72 \\
\hline TOTAL & --- & --- & --- & --- & --- & --- & --- & 21.12 & 2.29 & 5.57 & 9.89 & 18.82 \\
\hline MEAN & --- & -- & --- & --- & --- & --- & -- & 0.68 & 0.08 & 0.18 & 0.33 & 0.61 \\
\hline MAX & --- & --- & --- & --- & --- & --- & --- & 8.3 & 1.1 & 1.6 & 0.61 & 0.83 \\
\hline MIN & --- & --- & --- & --- & --- & --- & --- & 0.00 & 0.00 & 0.00 & 0.08 & 0.40 \\
\hline MEDIAN & --- & --- & --- & --- & --- & --- & --- & 0.00 & 0.00 & 0.00 & 0.32 & 0.57 \\
\hline ACRE-FT & --- & --- & --- & --- & --- & --- & --- & 42 & 4.5 & 11 & 20 & 37 \\
\hline CFSM & --- & --- & --- & --- & --- & --- & --- & 0.00 & 0.00 & 0.00 & 0.00 & 0.00 \\
\hline
\end{tabular}


Table 4. Daily mean discharge for Clear Creek near Winslow, AZ (09399000), calendar year 2006.

[e, estimated; CFSM, cubic feet per square mile; dashes indicate no data]

\begin{tabular}{|c|c|c|c|c|c|c|c|c|c|c|c|c|}
\hline \multicolumn{13}{|c|}{ Discharge, in cubic feet per second, calendar year 2006 — daily mean values } \\
\hline DAY & JAN & FEB & MAR & APR & MAY & JUN & JUL & AUG & SEP & ОСТ & NOV & DEC \\
\hline 1 & 0.60 & 2.6 & 1.5 & 0.64 & 0.43 & 0.06 & 0.78 & 1.5 & 0.21 & 0.24 & 0.60 & 0.61 \\
\hline 2 & 0.60 & 2.7 & 1.3 & 0.66 & 0.47 & 0.10 & 0.82 & 1.1 & 0.19 & 0.20 & 0.61 & 0.65 \\
\hline 3 & 0.61 & 2.6 & 1.3 & 0.67 & 0.42 & 0.14 & 0.77 & 0.71 & 0.18 & 0.19 & 0.61 & 0.66 \\
\hline 4 & 0.61 & 2.6 & 1.1 & 0.66 & 0.40 & 0.19 & 0.69 & 5.0 & 0.21 & 0.17 & 0.61 & 0.71 \\
\hline 5 & 0.69 & 2.6 & 1.00 & 0.51 & 0.37 & 0.23 & 0.69 & 5.1 & 0.20 & 0.22 & 0.62 & 0.76 \\
\hline 6 & 0.69 & 2.5 & 0.89 & 0.45 & 0.40 & 0.23 & 0.68 & 4.2 & 0.15 & 1.3 & 0.74 & 0.76 \\
\hline 7 & 0.69 & 2.5 & 0.75 & 0.49 & 0.45 & 0.23 & 0.67 & 3.3 & 0.14 & 1.7 & 0.82 & 0.77 \\
\hline 8 & 0.69 & 2.5 & 0.68 & 0.50 & 0.39 & 0.41 & 0.70 & 2.3 & 0.32 & 1.4 & 0.88 & 0.81 \\
\hline 9 & 0.69 & 2.5 & 0.61 & 0.48 & 0.34 & 0.55 & 0.88 & 1.8 & 0.28 & 1.2 & 0.83 & 0.84 \\
\hline 10 & 0.69 & 2.5 & 0.41 & 0.33 & 0.38 & 0.57 & 0.85 & 1.5 & 0.24 & 1.1 & 0.77 & 0.82 \\
\hline 11 & 0.69 & 2.5 & 0.48 & 0.27 & 0.42 & 0.52 & 0.75 & 1.3 & 0.22 & 0.92 & 0.75 & 0.84 \\
\hline 12 & 0.69 & 2.5 & 0.45 & 0.27 & 0.41 & 0.50 & 0.48 & 1.3 & 0.21 & 0.90 & 0.76 & 0.84 \\
\hline 13 & 0.82 & 2.5 & 0.45 & 0.29 & 0.35 & 0.45 & 0.39 & 1.6 & 0.19 & 0.84 & 0.77 & 0.84 \\
\hline 14 & 1.3 & 2.5 & 0.49 & 0.25 & 0.31 & 0.40 & 0.26 & 2.3 & 0.20 & 0.90 & 0.80 & 0.84 \\
\hline 15 & 1.6 & 1.9 & 0.53 & 0.21 & 0.32 & 0.39 & 0.22 & 2.3 & 0.60 & 0.90 & 0.79 & 0.84 \\
\hline 16 & 1.9 & 1.6 & 0.59 & 0.22 & 0.31 & 0.43 & 0.14 & 2.3 & 0.43 & 0.78 & 0.84 & 0.80 \\
\hline 17 & 2.1 & 1.8 & 0.60 & 0.22 & 0.34 & 0.45 & 0.07 & 11 & 0.32 & 0.52 & 0.84 & 0.73 \\
\hline 18 & 2.3 & 1.9 & 0.53 & 0.22 & 0.35 & 0.46 & 0.04 & 5.1 & 0.22 & 0.45 & 0.88 & 0.76 \\
\hline 19 & 2.3 & 2.0 & 0.55 & 0.26 & 0.31 & 0.46 & 0.00 & 2.4 & 0.15 & 0.45 & 0.91 & 0.76 \\
\hline 20 & 2.4 & 2.2 & 0.52 & 0.29 & 0.29 & 0.45 & 0.04 & 1.7 & 0.10 & 0.45 & 0.90 & 0.76 \\
\hline 21 & 3.3 & 2.3 & 0.52 & 0.31 & 0.25 & 0.45 & 0.06 & 1.3 & 0.05 & 0.47 & 0.83 & 0.75 \\
\hline 22 & 3.7 & 2.4 & 0.61 & 0.28 & 0.18 & 0.46 & 0.04 & 0.95 & 0.05 & 0.53 & 0.79 & 0.74 \\
\hline 23 & 5.0 & 2.4 & 0.65 & 0.22 & 0.20 & 0.51 & 0.03 & 0.82 & 0.05 & 0.61 & 0.78 & 0.70 \\
\hline 24 & 4.1 & 2.3 & 0.69 & 0.21 & 0.26 & 0.58 & 0.05 & 0.65 & 0.05 & 0.71 & 0.78 & 0.69 \\
\hline 25 & 3.4 & 2.0 & 0.69 & 0.21 & 0.29 & 0.56 & 0.05 & 0.69 & 0.08 & 0.80 & 0.77 & 0.68 \\
\hline 26 & 3.4 & 1.9 & 0.70 & 0.22 & 0.26 & 0.55 & 0.02 & 0.79 & 0.15 & 0.77 & 0.76 & 0.74 \\
\hline 27 & 3.2 & 1.9 & 0.72 & 0.21 & 0.18 & 0.58 & 0.01 & 0.62 & 0.20 & 0.73 & 0.69 & 0.73 \\
\hline 28 & 3.0 & 1.7 & 0.77 & 0.22 & 0.03 & 0.67 & 0.00 & 0.45 & 0.21 & 0.65 & 0.56 & 0.91 \\
\hline 29 & 2.8 & --- & 0.63 & 0.29 & 0.00 & 0.65 & 0.00 & 0.36 & 0.22 & 0.63 & 0.63 & 1.3 \\
\hline 30 & 2.7 & --- & 0.64 & 0.34 & 0.00 & 0.69 & 2.0 & 0.28 & 0.26 & 0.61 & 0.61 & 1.3 \\
\hline 31 & 2.7 & --- & 0.66 & --- & 0.02 & -- & 2.1 & 0.22 & --- & 0.60 & --- & 1.2 \\
\hline TOTAL & 59.96 & 63.9 & 22.01 & 10.40 & 9.13 & 12.92 & 14.28 & 64.94 & 6.08 & 21.94 & 22.53 & 25.14 \\
\hline MEAN & 1.93 & 2.28 & 0.71 & 0.35 & 0.29 & 0.43 & 0.46 & 2.09 & 0.20 & 0.71 & 0.75 & 0.81 \\
\hline MAX & 5.0 & 2.7 & 1.5 & 0.67 & 0.47 & 0.69 & 2.1 & 11 & 0.60 & 1.7 & 0.91 & 1.3 \\
\hline MIN & 0.60 & 1.6 & 0.41 & 0.21 & 0.00 & 0.06 & 0.00 & 0.22 & 0.05 & 0.17 & 0.56 & 0.61 \\
\hline MEDIAN & 1.9 & 2.5 & 0.64 & 0.28 & 0.32 & 0.46 & 0.26 & 1.5 & 0.20 & 0.65 & 0.77 & 0.76 \\
\hline ACRE-FT & 119 & 127 & 44 & 21 & 18 & 26 & 28 & 129 & 12 & 44 & 45 & 50 \\
\hline CFSM & 0.00 & 0.00 & 0.00 & 0.00 & 0.00 & 0.00 & 0.00 & 0.00 & 0.00 & 0.00 & 0.00 & 0.00 \\
\hline Calendar & Year 2006 & TOTA & 333.23 & MEAN & & X 11 & MIN 0.00 & MEDI & N 0.65 & ACRE-F & 661 & CFSM 0.00 \\
\hline
\end{tabular}


Table 5. Daily mean discharge for Clear Creek near Winslow, AZ (09399000), calendar year 2007.

[e, estimated; CFSM, cubic feet per square mile; dashes indicate no data]

\begin{tabular}{|c|c|c|c|c|c|c|c|c|c|c|c|c|}
\hline \multicolumn{13}{|c|}{ Discharge, in cubic feet per second, calendar year 2007—daily mean values } \\
\hline DAY & JAN & FEB & MAR & APR & MAY & JUN & JUL & AUG & SEP & OCT & NOV & DEC \\
\hline 1 & 1.2 & 4.3 & 1.9 & 67 & 2.6 & 0.05 & 0.00 & 0.00 & 0.00 & --- & --- & --- \\
\hline 2 & 1.2 & 3.4 & 2.0 & 51 & 3.3 & 0.23 & 0.00 & 0.00 & 0.00 & --- & --- & --- \\
\hline 3 & 1.2 & 3.1 & 2.2 & 45 & 2.7 & 0.65 & 0.00 & 0.00 & 0.00 & --- & --- & --- \\
\hline 4 & 1.1 & 3.0 & 2.3 & 39 & 2.1 & 0.98 & 0.00 & 0.00 & 0.00 & --- & --- & --- \\
\hline 5 & 1.1 & 3.0 & 2.8 & 34 & 2.0 & 1.1 & 0.00 & 30 & --- & --- & --- & --- \\
\hline 6 & 0.99 & 3.0 & 4.2 & 28 & 2.1 & 0.99 & 0.00 & 9.8 & --- & --- & --- & --- \\
\hline 7 & 0.92 & 3.0 & 3.8 & 23 & 2.2 & 1.2 & 0.00 & 4.6 & --- & --- & --- & --- \\
\hline 8 & 0.92 & 2.8 & 3.4 & 18 & 2.3 & 1.4 & 0.00 & 2.0 & --- & --- & --- & --- \\
\hline 9 & 0.92 & 2.6 & 3.2 & 15 & 2.4 & 1.5 & 0.00 & 1.1 & --- & --- & --- & --- \\
\hline 10 & 1.0 & 2.6 & 3.0 & 13 & 2.4 & 1.6 & 0.00 & 0.46 & --- & --- & --- & --- \\
\hline 11 & 1.4 & 2.8 & 2.8 & 13 & 2.4 & 2.1 & 0.00 & 0.12 & --- & --- & --- & --- \\
\hline 12 & 1.6 & 3.1 & 2.6 & 10 & 2.3 & 2.3 & 0.00 & 0.00 & --- & --- & --- & --- \\
\hline 13 & 1.8 & 3.3 & 2.6 & 9.8 & 2.2 & 1.8 & 0.00 & 0.00 & --- & --- & --- & --- \\
\hline 14 & 2.0 & 4.3 & 2.5 & 9.2 & 2.2 & 1.9 & 0.00 & 0.00 & --- & --- & --- & --- \\
\hline 15 & 2.1 & 4.0 & 2.5 & 6.0 & 2.1 & 2.0 & 0.00 & 0.00 & --- & --- & --- & --- \\
\hline 16 & 2.2 & 3.4 & 42 & 4.5 & 2.2 & 2.0 & 0.00 & 0.00 & --- & --- & --- & --- \\
\hline 17 & 2.3 & 3.3 & 197 & 4.4 & 2.3 & 1.8 & 0.00 & 0.00 & --- & --- & --- & --- \\
\hline 18 & 2.4 & 3.0 & 200 & 3.0 & 2.3 & 1.8 & 0.00 & 0.00 & --- & --- & --- & --- \\
\hline 19 & 2.5 & 2.7 & 193 & 2.2 & 2.3 & 1.8 & 0.00 & 0.00 & --- & --- & --- & --- \\
\hline 20 & 2.8 & 2.5 & 185 & 2.2 & 2.4 & 1.8 & 0.00 & 0.00 & --- & --- & --- & --- \\
\hline 21 & 3.1 & 2.6 & 151 & 2.2 & 2.2 & 1.3 & 0.00 & 0.00 & --- & --- & --- & --- \\
\hline 22 & 3.4 & 2.6 & 132 & 2.3 & 2.1 & 0.90 & 0.00 & 0.00 & --- & --- & --- & --- \\
\hline 23 & 3.7 & 2.2 & 107 & 2.2 & 2.0 & 0.62 & 0.00 & 0.00 & --- & --- & --- & --- \\
\hline 24 & 4.1 & 2.1 & 185 & 2.2 & 2.1 & 0.34 & 4.1 & 0.00 & --- & --- & --- & --- \\
\hline 25 & 4.2 & 2.1 & 545 & 2.4 & 2.1 & 0.20 & 6.6 & 0.00 & --- & --- & --- & --- \\
\hline 26 & 4.2 & 2.1 & 328 & 2.4 & 2.1 & 0.13 & 2.6 & 0.00 & --- & --- & --- & --- \\
\hline 27 & 4.2 & 2.1 & 182 & 2.5 & 2.0 & 0.08 & 1.5 & 0.00 & --- & --- & --- & --- \\
\hline 28 & 4.2 & 1.9 & 145 & 2.6 & 2.0 & 0.03 & 0.82 & 0.00 & --- & --- & --- & --- \\
\hline 29 & 4.2 & --- & 116 & 2.5 & 1.8 & 0.00 & 0.23 & 0.00 & --- & --- & --- & --- \\
\hline 30 & 4.2 & --- & 97 & 2.5 & 0.93 & 0.00 & 0.02 & 0.00 & --- & --- & --- & --- \\
\hline 31 & 4.4 & --- & 81 & --- & 0.00 & --- & 0.00 & 0.00 & --- & --- & --- & --- \\
\hline TOTAL & 75.55 & 80.9 & 2927.8 & 421.1 & 66.13 & 32.60 & 15.87 & 48.08 & --- & --- & --- & --- \\
\hline MEAN & 2.44 & 2.89 & 94.4 & 14.0 & 2.13 & 1.09 & 0.51 & 1.55 & --- & --- & --- & --- \\
\hline MAX & 4.4 & 4.3 & 545 & 67 & 3.3 & 2.3 & 6.6 & 30 & --- & --- & --- & --- \\
\hline MIN & 0.92 & 1.9 & 1.9 & 2.2 & 0.00 & 0.00 & 0.00 & 0.00 & --- & --- & --- & --- \\
\hline MEDIAN & 2.2 & 2.9 & 42 & 5.2 & 2.2 & 1.2 & 0.00 & 0.00 & --- & --- & --- & --- \\
\hline ACRE-FT & 150 & 160 & 5810 & 835 & 131 & 65 & 31 & 95 & --- & --- & --- & --- \\
\hline CFSM & 0.00 & 0.00 & 0.15 & 0.02 & 0.00 & 0.00 & 0.00 & 0.00 & --- & --- & --- & --- \\
\hline
\end{tabular}


Table 6. Daily mean discharge for Clear Creek below McHood Lake, near Winslow, AZ (09399100), calendar year 2005. [e, estimated; CFSM, cubic feet per square mile; dashes indicate no data]

\begin{tabular}{|c|c|c|c|c|c|c|c|c|c|c|c|c|}
\hline \multicolumn{13}{|c|}{ Discharge, in cubic feet per second, calendar year 2005—daily mean values } \\
\hline DAY & JAN & FEB & MAR & APR & MAY & JUN & JUL & AUG & SEP & OCT & NOV & DEC \\
\hline 1 & --- & --- & --- & --- & --- & --- & --- & --- & --- & 4.7 & 3.7 & 3.9 \\
\hline 2 & --- & --- & --- & --- & --- & --- & --- & --- & --- & 4.8 & 3.7 & 4.0 \\
\hline 3 & --- & --- & --- & --- & --- & --- & --- & --- & --- & 4.7 & 3.7 & 3.9 \\
\hline 4 & --- & --- & --- & --- & --- & --- & --- & --- & --- & 4.4 & 3.8 & 3.8 \\
\hline 5 & --- & --- & --- & --- & --- & --- & --- & --- & --- & 4.0 & 3.7 & 3.8 \\
\hline 6 & --- & --- & --- & --- & --- & --- & --- & --- & --- & 3.9 & 3.7 & 3.7 \\
\hline 7 & --- & --- & --- & --- & --- & --- & --- & --- & --- & 3.9 & 3.7 & 3.7 \\
\hline 8 & --- & --- & --- & --- & --- & --- & --- & --- & --- & 3.9 & 3.7 & 3.8 \\
\hline 9 & --- & --- & --- & --- & --- & --- & --- & --- & --- & 3.9 & 3.7 & 3.8 \\
\hline 10 & --- & --- & --- & --- & --- & --- & --- & --- & --- & 3.9 & 3.7 & 3.8 \\
\hline 11 & --- & --- & --- & --- & --- & --- & --- & --- & --- & 3.9 & 3.8 & 3.8 \\
\hline 12 & --- & --- & --- & --- & --- & --- & --- & --- & --- & 3.8 & 3.7 & 3.8 \\
\hline 13 & --- & --- & --- & --- & --- & --- & --- & --- & --- & 3.9 & 3.8 & 3.8 \\
\hline 14 & --- & --- & --- & --- & --- & --- & --- & --- & --- & 3.9 & 3.8 & 3.8 \\
\hline 15 & --- & --- & --- & --- & --- & --- & --- & --- & --- & 3.8 & 3.8 & 3.8 \\
\hline 16 & --- & --- & --- & --- & --- & --- & --- & --- & --- & 3.9 & 3.8 & 3.8 \\
\hline 17 & --- & --- & --- & --- & --- & --- & --- & --- & --- & 3.9 & 3.8 & 3.8 \\
\hline 18 & --- & --- & --- & --- & --- & --- & --- & --- & --- & 3.9 & 3.8 & 3.8 \\
\hline 19 & --- & --- & --- & --- & --- & --- & --- & --- & --- & 3.8 & 3.8 & 3.8 \\
\hline 20 & --- & --- & --- & --- & --- & --- & --- & --- & --- & 3.8 & 3.8 & 3.8 \\
\hline 21 & --- & --- & --- & --- & --- & --- & --- & --- & --- & 3.8 & 3.8 & 3.7 \\
\hline 22 & --- & --- & --- & --- & --- & --- & --- & --- & --- & 3.8 & 3.8 & 3.8 \\
\hline 23 & --- & --- & --- & --- & --- & --- & --- & --- & --- & 3.8 & 3.9 & 3.9 \\
\hline 24 & --- & --- & --- & --- & --- & --- & --- & --- & --- & 3.8 & 3.9 & 3.9 \\
\hline 25 & --- & --- & --- & --- & --- & --- & --- & --- & --- & 3.8 & 3.9 & 3.9 \\
\hline 26 & --- & --- & --- & --- & --- & --- & --- & --- & --- & 3.8 & 4.0 & 4.0 \\
\hline 27 & --- & --- & --- & --- & --- & --- & --- & --- & --- & 3.8 & 3.9 & 3.9 \\
\hline 28 & --- & --- & --- & --- & --- & --- & --- & --- & e 4.3 & 3.8 & 3.8 & 3.9 \\
\hline 29 & --- & --- & --- & --- & --- & --- & --- & --- & 4.5 & 3.8 & 3.8 & 3.9 \\
\hline 30 & --- & --- & --- & --- & --- & --- & --- & --- & 4.6 & 3.8 & 3.8 & 3.9 \\
\hline 31 & --- & --- & --- & --- & --- & --- & --- & --- & --- & 3.8 & --- & 4.4 \\
\hline TOTAL & --- & --- & --- & --- & --- & --- & --- & --- & --- & 122.5 & 113.6 & 119.4 \\
\hline MEAN & -- & --- & --- & --- & --- & --- & --- & --- & --- & 3.95 & 3.79 & 3.85 \\
\hline MAX & --- & --- & --- & --- & --- & --- & --- & --- & --- & 4.8 & 4.0 & 4.4 \\
\hline MIN & --- & --- & --- & --- & --- & --- & --- & --- & --- & 3.8 & 3.7 & 3.7 \\
\hline MEDIAN & --- & --- & --- & --- & --- & --- & --- & --- & --- & 3.9 & 3.8 & 3.8 \\
\hline ACRE-FT & --- & --- & --- & --- & --- & --- & --- & --- & --- & 243 & 225 & 237 \\
\hline
\end{tabular}


Table 7. Daily mean discharge for Clear Creek below McHood Lake, near Winslow, AZ (09399100), calendar year 2006. [e, estimated; CFSM, cubic feet per square mile; dashes indicate no data]

\begin{tabular}{|c|c|c|c|c|c|c|c|c|c|c|c|c|}
\hline \multicolumn{13}{|c|}{ Discharge, in cubic feet per second, calendar year 2006 — daily mean values } \\
\hline DAY & JAN & FEB & MAR & APR & MAY & JUN & JUL & AUG & SEP & ОСТ & NOV & DEC \\
\hline 1 & 4 & 3.4 & 4.6 & 4.7 & 4.7 & 4.1 & 4.3 & --- & --- & e4.4 & e4.4 & 4.4 \\
\hline 2 & 4 & 3.4 & 4.4 & 4.7 & 4.7 & 4.1 & 4.4 & -- & --- & e 4.4 & e 4.4 & 4.4 \\
\hline 3 & 4 & 3.3 & 4.3 & 4.7 & 4.7 & 4.3 & 4.4 & -- & --- & e 4.4 & e 4.4 & 4.4 \\
\hline 4 & 4 & 3.4 & 4.6 & 4.7 & 4.7 & 4.1 & 4.4 & --- & --- & e 4.4 & e4.4 & 4.4 \\
\hline 5 & 4 & 3.3 & 4.5 & 5 & 4.7 & 4 & 4.2 & --- & --- & e4.4 & e4.4 & 4.4 \\
\hline 6 & 4.5 & 3.3 & 4.5 & 4.7 & 4.7 & 4.1 & 4.4 & --- & --- & $\mathrm{e} 4.4$ & $\mathrm{e} 4.4$ & 4.4 \\
\hline 7 & 4 & 3.3 & 4.6 & 4.7 & 4.7 & 4.2 & 4.3 & --- & --- & e4.4 & e4.4 & 4.4 \\
\hline 8 & 4 & 3.3 & 4.5 & 4.8 & 4.8 & 4.1 & 4.3 & --- & --- & e4.4 & 4.4 & 4.4 \\
\hline 9 & 4 & 3.3 & 4.5 & 4.8 & 4.7 & 4.1 & 4.4 & --- & --- & e4.4 & 4.4 & 4.4 \\
\hline 10 & 4.1 & 3.3 & 4.7 & 4.8 & 4.7 & 4.3 & $\mathrm{e} 4.3$ & --- & --- & e4.4 & 4.4 & 4.4 \\
\hline 11 & 4.2 & 3.3 & 4.5 & 4.6 & 4.8 & 4.2 & e 4.2 & --- & --- & e4.4 & 4.4 & 4.4 \\
\hline 12 & 4.3 & 3.3 & 4.7 & 4.6 & 4.8 & 4.4 & 4.2 & --- & --- & e4.4 & 4.4 & 4.4 \\
\hline 13 & 4.4 & 3.3 & 4.4 & 4.6 & 4.8 & 4.4 & 4 & --- & --- & $\mathrm{e} 4.4$ & 4.4 & 4.4 \\
\hline 14 & 4.6 & 3.4 & 4.4 & 4.8 & 4.8 & 4.2 & 3.9 & --- & --- & e4.4 & 4.4 & 4.4 \\
\hline 15 & 4.6 & 4.8 & 4.5 & 4.6 & 4.8 & 4 & 3.9 & --- & --- & e4.4 & 4.4 & 4.4 \\
\hline 16 & 4 & 4.6 & e 4.5 & 4.6 & 4.8 & 3.9 & 4 & --- & --- & e4.4 & 4.4 & 4.3 \\
\hline 17 & 3.9 & 4.8 & e4.6 & 4.7 & 4.8 & 4 & 4 & --- & --- & e4.4 & 4.4 & 4.3 \\
\hline 18 & 3.9 & 4.9 & 4.7 & 4.6 & 4.9 & 4 & 4 & --- & --- & e4.4 & 4.4 & 4.3 \\
\hline 19 & 3.7 & 4.9 & 4.5 & 4.6 & 4.7 & 4 & --- & --- & --- & e4.4 & 4.4 & 4.2 \\
\hline 20 & 3.1 & 4.9 & 4.5 & 4.7 & 4.8 & 4 & --- & --- & --- & e4.4 & 4.4 & 4.2 \\
\hline 21 & 2.9 & 4.9 & 4.5 & 4.7 & 4.7 & 3.9 & --- & --- & --- & e4.4 & 4.4 & 4.2 \\
\hline 22 & 3.2 & 4.9 & 4.5 & 4.7 & 4.9 & 4 & --- & --- & --- & e4.4 & 4.4 & 4.2 \\
\hline 23 & 3.3 & 5 & 4.5 & 4.7 & 4.7 & 4 & --- & --- & --- & e4.4 & 4.4 & 4.1 \\
\hline 24 & 3.5 & 4.9 & 4.5 & 4.6 & 4.4 & 4.1 & --- & --- & --- & e4.4 & 4.4 & 4.1 \\
\hline 25 & 3.5 & 4.5 & 4.6 & 4.6 & 4.1 & 4.2 & --- & --- & --- & e4.4 & 4.4 & 4.1 \\
\hline 26 & 3.5 & 4 & 4.6 & 4.6 & 4.1 & 4.2 & --- & --- & --- & e4.4 & 4.4 & 4.1 \\
\hline 27 & 3.5 & 4.2 & 4.6 & 4.6 & 4.2 & 4.1 & --- & --- & --- & e4.4 & 4.4 & 4.1 \\
\hline 28 & 3.4 & 4.7 & 4.7 & 4.6 & 4.1 & 4.1 & --- & --- & --- & e4.4 & 4.4 & 4.1 \\
\hline 29 & 3.4 & --- & 4.9 & 4.6 & 4.1 & 4.1 & --- & --- & --- & e4.4 & 4.4 & 4.3 \\
\hline 30 & 3.4 & --- & 4.6 & 4.6 & 4.1 & 4.2 & --- & --- & --- & e4.4 & 4.4 & 4.3 \\
\hline 31 & 3.4 & --- & 4.7 & --- & 4 & --- & --- & --- & --- & e4.4 & --- & 4.2 \\
\hline TOTAL & 118.3 & 112.6 & 141.2 & 140.3 & 142.5 & 123.4 & --- & --- & --- & 136.4 & 132 & 133.1 \\
\hline MEAN & 3.82 & 4.02 & 4.55 & 4.68 & 4.6 & 4.11 & --- & --- & --- & 4.4 & 4.4 & 4.29 \\
\hline MAX & 4.6 & 5 & 4.9 & 5 & 4.9 & 4.4 & --- & --- & --- & 4.4 & 4.4 & 4.4 \\
\hline MIN & 2.9 & 3.3 & 4.3 & 4.6 & 4 & 3.9 & --- & --- & --- & 4.4 & 4.4 & 4.1 \\
\hline MEDIAN & 4 & 3.7 & 4.5 & 4.7 & 4.7 & 4.1 & --- & --- & --- & 4.4 & 4.4 & 4.3 \\
\hline ACRE-FT & 235 & 223 & 280 & 278 & 283 & 245 & --- & --- & --- & 271 & 262 & 264 \\
\hline
\end{tabular}


Table 8. Daily mean discharge for Clear Creek below McHood Lake, near Winslow, AZ (09399100), calendar year 2007.

[e, estimated; CFSM, cubic feet per square mile; dashes indicate no data]

\section{Discharge, in cubic feet per second, calendar year 2007-daily mean values}

\begin{tabular}{|c|c|c|c|c|c|c|c|c|c|c|c|c|}
\hline DAY & JAN & FEB & MAR & APR & MAY & JUN & JUL & AUG & SEP & ОСТ & NOV & DEC \\
\hline 1 & 4.2 & 4.4 & 3.6 & e3.6 & 1.6 & 0.81 & 0.49 & 30 & 15 & --- & --- & --- \\
\hline 2 & 4.2 & 4.3 & 3.7 & e3.6 & 1.6 & 0.82 & 0.49 & 36 & 15 & --- & --- & --- \\
\hline 3 & 4.1 & 4.2 & 3.7 & e3.6 & 1.7 & 0.87 & 0.5 & 28 & 15 & --- & --- & --- \\
\hline 4 & 4.1 & 4.2 & 3.6 & e3.6 & 1.7 & 0.89 & 0.5 & 28 & 15 & --- & --- & --- \\
\hline 5 & 4.1 & 4.2 & 3.4 & e3.6 & 1.4 & 0.91 & 0.5 & 64 & --- & --- & --- & --- \\
\hline 6 & 4 & 4.2 & 3.6 & e3.6 & 1.4 & 0.95 & 0.49 & 66 & --- & --- & --- & --- \\
\hline 7 & 4 & 4.2 & 4 & e3.6 & 1.4 & 0.83 & 0.49 & 58 & --- & --- & --- & --- \\
\hline 8 & 4 & 4.2 & 4 & 3.6 & 1.5 & 0.86 & 0.49 & 76 & --- & --- & --- & --- \\
\hline 9 & 4 & 4.2 & 4 & 3.4 & 1.5 & 0.88 & 0.48 & 35 & --- & --- & --- & --- \\
\hline 10 & 4 & 4.2 & 3.9 & 3 & 1.5 & 0.84 & 0.48 & 31 & --- & --- & --- & --- \\
\hline 11 & 4.1 & 4.2 & 3.9 & 2.7 & 1.5 & 0.72 & 0.48 & 26 & --- & --- & --- & --- \\
\hline 12 & 4.2 & 4.3 & 3.8 & 2.5 & 1.5 & 1 & 0.48 & 24 & --- & --- & --- & --- \\
\hline 13 & 4.2 & 4.3 & 3.8 & 2.2 & 1.4 & 0.91 & 0.49 & 23 & --- & --- & --- & --- \\
\hline 14 & 4.3 & 4.4 & 3.8 & 2.1 & 1.4 & 0.92 & 0.49 & 21 & --- & --- & --- & --- \\
\hline 15 & 4.4 & e4.1 & 3.8 & 2.2 & 1.4 & 0.93 & 0.49 & 20 & --- & --- & --- & --- \\
\hline 16 & 4.4 & 4.1 & e3.8 & 1.8 & 1.4 & 0.89 & 0.49 & 19 & --- & --- & --- & --- \\
\hline 17 & 4.4 & 4.2 & e3.8 & 1.8 & 1.4 & 0.86 & 0.49 & 18 & --- & --- & --- & --- \\
\hline 18 & 4.4 & 4.1 & e3.8 & 2.1 & 1.3 & 0.84 & 0.49 & 18 & --- & --- & --- & --- \\
\hline 19 & 4.4 & 4.2 & e3.8 & 1.5 & 1.3 & 0.84 & 0.5 & 17 & --- & --- & --- & --- \\
\hline 20 & 4.4 & 4 & e3.8 & 1.5 & 1.3 & 0.84 & 0.51 & 17 & --- & --- & --- & --- \\
\hline 21 & 4.4 & 4 & e3.8 & 1.5 & 1.3 & 0.75 & 0.54 & 17 & --- & --- & --- & --- \\
\hline 22 & 4.4 & 4 & e 3.8 & 1.5 & 1.2 & 0.69 & 1.3 & 17 & --- & --- & --- & --- \\
\hline 23 & 4.4 & 4.1 & e 3.8 & 1.6 & 1.2 & 0.65 & 0.54 & --- & --- & --- & --- & --- \\
\hline 24 & 4.4 & 3.9 & e3.8 & 1.5 & 1.1 & 0.6 & 0.93 & --- & --- & --- & --- & --- \\
\hline 25 & 4.4 & 4 & e3.8 & 1.5 & 1.1 & 0.57 & 1.3 & --- & --- & --- & --- & --- \\
\hline 26 & 4.4 & 3.9 & e3.8 & 1.5 & 1.1 & 0.54 & 0.97 & --- & --- & --- & --- & --- \\
\hline 27 & 4.4 & 3.9 & e3.8 & 1.5 & 1.1 & 0.53 & 26 & --- & --- & --- & --- & --- \\
\hline 28 & 4.4 & 3.9 & e3.8 & 1.5 & 1.1 & 0.53 & 12 & --- & --- & --- & --- & --- \\
\hline 29 & 4.4 & --- & e 3.7 & 1.5 & 1 & 0.52 & 47 & --- & --- & --- & --- & --- \\
\hline 30 & 4.4 & --- & e 3.7 & 1.6 & 1 & 0.5 & 43 & --- & --- & --- & --- & --- \\
\hline 31 & 4.4 & --- & e 3.7 & --- & 0.9 & --- & 15 & --- & --- & --- & --- & --- \\
\hline TOTAL & 132.3 & 115.9 & 117.1 & 70.8 & 41.3 & 23.29 & 158.4 & --- & --- & --- & --- & --- \\
\hline MEAN & 4.27 & 4.14 & 3.78 & 2.36 & 1.33 & 0.78 & 5.11 & --- & --- & --- & --- & --- \\
\hline MAX & 4.4 & 4.4 & 4 & 3.6 & 1.7 & 1 & 47 & --- & --- & --- & --- & --- \\
\hline MIN & 4 & 3.9 & 3.4 & 1.5 & 0.9 & 0.5 & 0.48 & --- & --- & --- & --- & --- \\
\hline MEDIAN & 4.4 & 4.2 & 3.8 & 2.1 & 1.4 & 0.84 & 0.5 & --- & --- & --- & --- & --- \\
\hline ACRE-FT & 262 & 230 & 232 & 140 & 82 & 46 & 314 & --- & --- & --- & --- & --- \\
\hline
\end{tabular}


Table 9. Daily mean discharge for Chevelon Creek near Winslow, AZ (09398000), calendar year 2005.

[e, estimated; CFSM, cubic feet per square mile; dashes indicate no data]

\section{Discharge, in cubic feet per second, calendar year 2005—daily mean values}

\begin{tabular}{|c|c|c|c|c|c|c|c|c|c|c|c|c|}
\hline DAY & JAN & FEB & MAR & APR & MAY & JUN & JUL & AUG & SEP & ОСТ & NOV & DEC \\
\hline 1 & --- & --- & --- & --- & --- & --- & --- & 17 & 3.1 & 2.5 & 2.7 & 4.2 \\
\hline 2 & --- & --- & --- & --- & --- & --- & --- & 6.2 & 19 & 2.3 & 2.8 & 3.2 \\
\hline 3 & --- & --- & --- & --- & --- & --- & --- & 3.1 & 16 & 2.2 & 2.8 & 3.8 \\
\hline 4 & --- & --- & --- & --- & --- & --- & --- & 2.8 & 9.2 & 2 & 2.9 & 3.9 \\
\hline 5 & --- & --- & --- & --- & --- & --- & --- & 3.1 & 2.6 & 2.3 & 3.1 & 3.2 \\
\hline 6 & --- & --- & --- & --- & --- & --- & --- & 5.9 & 1.9 & 2.5 & 3 & 3.2 \\
\hline 7 & --- & --- & --- & --- & --- & --- & --- & 4.2 & 1.8 & 2.4 & 3.2 & 3.2 \\
\hline 8 & --- & --- & --- & --- & --- & --- & --- & 3 & 3.7 & 2.1 & 3.2 & 3.2 \\
\hline 9 & --- & --- & --- & --- & --- & --- & --- & 3 & 2.3 & 5.7 & 3.3 & 3.2 \\
\hline 10 & --- & --- & --- & --- & --- & --- & --- & 3 & 1.6 & 5.2 & 3.4 & 3.2 \\
\hline 11 & --- & --- & --- & --- & --- & --- & --- & 3 & 1.5 & 2.4 & 3.2 & 3.2 \\
\hline 12 & --- & --- & --- & --- & --- & --- & --- & 3 & 1.4 & 2.2 & 3.4 & 3.2 \\
\hline 13 & --- & --- & --- & --- & --- & --- & --- & 3 & 1.5 & 2.2 & 3.5 & 3.5 \\
\hline 14 & --- & --- & --- & --- & --- & --- & --- & 2.9 & 1.6 & 2.2 & 3.5 & 3.5 \\
\hline 15 & --- & --- & --- & --- & --- & --- & --- & 4.7 & 1.8 & 2.2 & 3.6 & 3.3 \\
\hline 16 & --- & --- & --- & --- & --- & --- & --- & 6.3 & 1.5 & 2.4 & 3.4 & 2.8 \\
\hline 17 & --- & --- & --- & --- & --- & --- & --- & 5.9 & 1.5 & 2.7 & 3.3 & 2 \\
\hline 18 & --- & --- & --- & --- & --- & --- & --- & 3.2 & 1.5 & 4 & 3.4 & 2.9 \\
\hline 19 & --- & --- & --- & --- & --- & --- & --- & 3 & 1.8 & 3.4 & 3.3 & 3.4 \\
\hline 20 & --- & --- & --- & --- & --- & --- & --- & 3 & 1.9 & 2.7 & 2.9 & 3.6 \\
\hline 21 & --- & --- & --- & --- & --- & --- & --- & 2.9 & 1.8 & 2.7 & 2.9 & 4 \\
\hline 22 & --- & --- & --- & --- & --- & --- & --- & 3 & 1.8 & 2.9 & 2.9 & 4 \\
\hline 23 & --- & --- & --- & --- & --- & --- & --- & 2.9 & 1.7 & 2.9 & 2.9 & 3.3 \\
\hline 24 & --- & --- & --- & --- & --- & --- & --- & 3 & 1.6 & 2.9 & 3.1 & 2.2 \\
\hline 25 & --- & --- & --- & --- & --- & --- & --- & 3 & 1.9 & 2.8 & 3.1 & 2.9 \\
\hline 26 & --- & --- & --- & --- & --- & --- & --- & 3.1 & 2.1 & 2.9 & 3 & 3.1 \\
\hline 27 & --- & --- & --- & --- & --- & --- & --- & 3.1 & 2.4 & 2.8 & 3.3 & 2.9 \\
\hline 28 & --- & --- & --- & --- & --- & --- & --- & 3.1 & 2.5 & 2.7 & 3.9 & 3 \\
\hline 29 & --- & --- & --- & --- & --- & --- & 2.6 & 3.1 & 2.5 & 2.7 & 4.2 & 3.2 \\
\hline 30 & --- & --- & --- & --- & --- & --- & 2.6 & 2.9 & 2.5 & 2.8 & 4 & e3.1 \\
\hline 31 & --- & --- & --- & --- & --- & --- & 24 & 2.9 & --- & 2.8 & --- & e3.0 \\
\hline TOTAL & --- & --- & --- & --- & --- & --- & --- & 122.3 & 98 & 86.5 & 97.2 & 100.4 \\
\hline MEAN & --- & --- & --- & --- & --- & --- & --- & 3.95 & 3.27 & 2.79 & 3.24 & 3.24 \\
\hline MAX & --- & --- & --- & --- & --- & --- & --- & 17 & 19 & 5.7 & 4.2 & 4.2 \\
\hline MIN & --- & --- & --- & --- & --- & --- & --- & 2.8 & 1.4 & 2 & 2.7 & 2 \\
\hline ACRE-FT & --- & --- & --- & --- & --- & --- & --- & 243 & 194 & 172 & 193 & 199 \\
\hline
\end{tabular}


Table 10. Daily mean discharge for Chevelon Creek near Winslow, AZ (09398000), calendar year 2006.

[e, estimated; CFSM, cubic feet per square mile; dashes indicate no data]

\begin{tabular}{|c|c|c|c|c|c|c|c|c|c|c|c|c|}
\hline \multicolumn{13}{|c|}{ Discharge, in cubic feet per second, calendar year 2006 — daily mean values } \\
\hline DAY & JAN & FEB & MAR & APR & MAY & JUN & JUL & AUG & SEP & ОСТ & NOV & DEC \\
\hline 1 & e3.0 & 3.6 & 3.6 & 4.1 & 2.8 & 2.4 & 2.3 & 71 & 2.7 & 3.1 & 3.7 & 4 \\
\hline 2 & e2.9 & 3.6 & 3.6 & 4.5 & 2.7 & 2.3 & 2.2 & 8.9 & 3 & 3.1 & 3.9 & 3.8 \\
\hline 3 & e2.9 & 3.6 & 3.4 & 4.4 & 2.5 & 2.4 & 2.2 & 3.9 & 3.2 & 3.1 & 3.6 & 3.6 \\
\hline 4 & e2.9 & 3.6 & 3.6 & 4.3 & 2.4 & 2.5 & 2.6 & 3.1 & 3.2 & 3.1 & 3.4 & 4.1 \\
\hline 5 & 2.7 & 3.6 & 3.6 & 3.9 & 2.4 & 2.5 & 2.6 & 3 & 3.1 & 4 & 3.4 & 4 \\
\hline 6 & 2.9 & 3.6 & 3.4 & 4.1 & 2.7 & 2.3 & 2.5 & 2.8 & 2.9 & 4.6 & 3.3 & 4 \\
\hline 7 & 2.7 & 3.6 & 3.1 & 4.1 & 2.7 & 2.2 & 2.5 & 420 & 2.9 & 3.4 & 3.6 & 4 \\
\hline 8 & 2.7 & 3.6 & 3.1 & 3.4 & 2.5 & 2.3 & 2.5 & 42 & 3.1 & 3.3 & 3.5 & 4 \\
\hline 9 & 2.7 & 3.6 & 3.2 & 3.3 & 2.5 & 2.2 & 2.9 & 5.3 & 2.8 & 3.3 & 3.3 & 4 \\
\hline 10 & 2.9 & 3.6 & 2.5 & 3.3 & 2.7 & 2.1 & 2.8 & 3.5 & 2.5 & 3.6 & 3.2 & 3.7 \\
\hline 11 & 2.9 & 3.6 & 3.2 & 3.6 & 3.1 & 1.9 & 2.2 & 3.2 & 2.4 & 3.6 & 3.1 & 3.9 \\
\hline 12 & 2.9 & 3.6 & 3.1 & 3.9 & 3 & 1.6 & 2.1 & 3.5 & 2.4 & 3.7 & 3.3 & 4 \\
\hline 13 & 2.9 & 3.6 & 3.2 & 4.5 & 2.7 & 1.6 & 2.3 & 3.6 & 2.4 & 4 & 3.4 & 4 \\
\hline 14 & 3.1 & 3.6 & 3.3 & 4.2 & 2.7 & 1.3 & 2.4 & 3.9 & 2.7 & 4.1 & 3.3 & 4 \\
\hline 15 & 2.9 & 2.6 & 3.4 & 4.1 & 2.7 & 1.6 & 2.4 & 4.9 & 3.9 & 4.4 & 3.6 & 4.2 \\
\hline 16 & 3.1 & 3.4 & 3.2 & 4.2 & 2.5 & 2.2 & 2.3 & 36 & 2.8 & 4.3 & 3.6 & 3.7 \\
\hline 17 & 3.2 & 3.5 & 3.3 & 3.9 & 2.3 & 2.2 & 2.4 & 29 & 2.5 & 3.8 & 3.6 & 3 \\
\hline 18 & 3.2 & 3.6 & 3.2 & 3.2 & 2 & 2.1 & 2.6 & 4.7 & 2.5 & 4.4 & 3.6 & 3.6 \\
\hline 19 & 3.2 & 3.7 & 3.3 & 3.2 & 1.9 & 2 & 2.4 & 2.8 & 2.6 & 4.2 & 3.8 & 4 \\
\hline 20 & 3.5 & 4.1 & 3.5 & 3.2 & 1.7 & 1.9 & 2.5 & 3 & 2 & 4.2 & 4 & 3.7 \\
\hline 21 & 3.6 & 4.4 & 3.5 & 2.7 & 1.8 & 2 & 2.4 & 2.9 & 2.4 & 3.7 & 4 & 3.7 \\
\hline 22 & 3.5 & 4.5 & 3.6 & 2.6 & 1.2 & 2.1 & 2.2 & 2.9 & 2.3 & 3.3 & 4 & 4 \\
\hline 23 & 3.6 & 4.5 & 3.6 & 2.3 & 1.9 & 2.2 & 3.5 & 2.7 & 2.9 & 3.6 & 4 & 4 \\
\hline 24 & 3.6 & 4.5 & 3.6 & 2.6 & 2.2 & 2.3 & 16 & 8.5 & 3.1 & 3.7 & 4.1 & 4 \\
\hline 25 & 3.7 & 4.2 & 3.8 & 2.7 & 2.1 & 2 & 22 & 6.4 & 3.2 & 3.7 & 3.9 & 4 \\
\hline 26 & 3.7 & 3.6 & 4.2 & 2.7 & 2 & 2.1 & 2.7 & 4 & 3.1 & 3.6 & 3.6 & 4 \\
\hline 27 & 3.6 & 3.6 & 4.4 & 2.6 & 1.5 & 2.2 & 2.4 & 2.5 & 3.2 & 3.6 & 3.3 & 3.5 \\
\hline 28 & 3.6 & 3.5 & 4.2 & 2.6 & 1.7 & 2.4 & 2.5 & 2.5 & 3.2 & 3.6 & 3.2 & 4.2 \\
\hline 29 & 3.6 & --- & 3.8 & 2.9 & 2.2 & 2.2 & 13 & 2.6 & 3.2 & 3.6 & 3.8 & 4.4 \\
\hline 30 & 3.6 & --- & 4.4 & 2.8 & 2.5 & 2.3 & 179 & 3.7 & 3.2 & 3.5 & 3.6 & 4 \\
\hline 31 & 3.6 & --- & 4.2 & --- & 2.5 & --- & 92 & 2.8 & --- & 3.6 & --- & 4 \\
\hline TOTAL & 98.9 & 104.1 & 109.1 & 103.9 & 72.1 & 63.4 & 386.4 & 699.6 & 85.4 & 114.8 & 107.7 & 121.1 \\
\hline MEAN & 3.19 & 3.72 & 3.52 & 3.46 & 2.33 & 2.11 & 12.5 & 22.6 & 2.85 & 3.7 & 3.59 & 3.91 \\
\hline MAX & 3.7 & 4.5 & 4.4 & 4.5 & 3.1 & 2.5 & 179 & 420 & 3.9 & 4.6 & 4.1 & 4.4 \\
\hline MIN & 2.7 & 2.6 & 2.5 & 2.3 & 1.2 & 1.3 & 2.1 & 2.5 & 2 & 3.1 & 3.1 & 3 \\
\hline ACRE-FT & 196 & 206 & 216 & 206 & 143 & 126 & 766 & 1,390 & 169 & 228 & 214 & 240 \\
\hline Calenda & r Year 20 & $\mathrm{TC}$ & TAL 2,06 & & EAN 5.66 & MA & K 420 & MIN 1.2 & AC-FT & 4,100 & & \\
\hline
\end{tabular}


Table 11. Daily mean discharge for Chevelon Creek near Winslow, AZ (09398000), calendar year 2007. [e, estimated; CFSM, cubic feet per square mile; dashes indicate no data]

\begin{tabular}{|c|c|c|c|c|c|c|c|c|c|c|c|c|}
\hline \multicolumn{13}{|c|}{ Discharge, in cubic feet per second, calendar year 2007—daily mean values } \\
\hline DAY & JAN & FEB & MAR & APR & MAY & JUN & JUL & AUG & SEP & ОСТ & NOV & DEC \\
\hline 1 & 4.1 & 4 & 4.1 & 22 & 5.3 & 3.1 & 2.8 & 192 & 4.2 & --- & --- & --- \\
\hline 2 & 4.1 & 3.6 & 14 & 15 & 5.3 & 3.1 & 2.9 & 282 & 258 & --- & --- & --- \\
\hline 3 & 4.4 & 3.6 & 17 & 11 & 4.1 & 3.2 & 2.9 & 8.4 & 277 & --- & --- & --- \\
\hline 4 & 4.1 & 3.6 & 22 & 11 & 3.3 & 3.3 & 3 & 85 & 25 & --- & --- & --- \\
\hline 5 & 3.9 & 3.6 & 20 & 9.3 & 4.3 & 2.8 & 3 & 218 & --- & --- & --- & --- \\
\hline 6 & 4 & 3.6 & 17 & 8 & 5 & 1.7 & 2.9 & 26 & --- & --- & --- & --- \\
\hline 7 & 4 & 3.6 & 13 & 6.5 & 5 & 2.9 & 3 & 137 & --- & --- & --- & --- \\
\hline 8 & 4 & 3.6 & 11 & 5.4 & 4.9 & 3 & 2.9 & 75 & --- & --- & --- & --- \\
\hline 9 & 4 & 3.5 & 9.7 & 4.9 & 4.9 & 2.9 & 2.9 & 136 & --- & --- & --- & --- \\
\hline 10 & 4 & 3.6 & 8.9 & 4.5 & 4.4 & 3 & 2.8 & 116 & --- & --- & --- & --- \\
\hline 11 & 3.9 & 3.8 & 220 & 4.8 & 2.7 & 3.5 & 2.8 & 77 & --- & --- & --- & --- \\
\hline 12 & 3.1 & 3.9 & 276 & 4 & 3.5 & 3.8 & 3.2 & 48 & --- & --- & --- & --- \\
\hline 13 & 3.7 & 4.7 & 253 & 4.9 & 2.3 & 3.4 & 3.1 & 29 & --- & --- & --- & --- \\
\hline 14 & 4 & 6.1 & 225 & 4.8 & 2 & 3.4 & 3.1 & 18 & --- & --- & --- & --- \\
\hline 15 & 3.7 & 5.3 & 227 & 3.8 & 2.2 & 3.1 & 2.9 & 11 & --- & --- & --- & --- \\
\hline 16 & 3.6 & 4.2 & 222 & 4.3 & 4.4 & 3 & 2.9 & 9.6 & --- & --- & --- & --- \\
\hline 17 & 3.6 & 4 & 185 & 4.6 & 4.7 & 2.8 & 3 & 7.7 & --- & --- & --- & --- \\
\hline 18 & 3.6 & 3.8 & 147 & 3.2 & 4.6 & 2.9 & 2.9 & 8.8 & --- & --- & --- & --- \\
\hline 19 & 3.6 & 3.5 & 115 & 4.2 & 4.6 & 3 & 3.1 & 6.5 & --- & --- & --- & --- \\
\hline 20 & 3.7 & 3.7 & 93 & 4.3 & 4.5 & 3.1 & 3.3 & 5.5 & --- & --- & --- & --- \\
\hline 21 & 4.2 & 4 & 72 & 4.5 & 3.9 & 3 & 5.3 & 4.8 & --- & --- & --- & --- \\
\hline 22 & 4.1 & 3.8 & 60 & 4.5 & 3.8 & 2.9 & 92 & 4.3 & --- & --- & --- & --- \\
\hline 23 & 3.7 & 3.1 & 56 & 3.9 & 4.3 & 2.6 & 34 & 4 & --- & --- & --- & --- \\
\hline 24 & 3.5 & 3.7 & 321 & 4.8 & 4.4 & 2.6 & 200 & 4 & --- & --- & --- & --- \\
\hline 25 & 3.5 & 3.5 & 501 & 4.9 & 4.3 & 2.7 & 69 & 3.9 & --- & --- & --- & --- \\
\hline 26 & 3.6 & 3.4 & 254 & 4.9 & 4 & 2.7 & 33 & 12 & --- & --- & --- & --- \\
\hline 27 & 3.6 & 3 & 143 & 5 & 3.9 & 2.7 & 10 & 27 & --- & --- & --- & --- \\
\hline 28 & 3.6 & 2.8 & 96 & 4.9 & 3.7 & 2.8 & 6.3 & 5.3 & --- & --- & --- & --- \\
\hline 29 & 3.6 & --- & 68 & 5.2 & 2.8 & 2.7 & 4.6 & 4.3 & --- & --- & --- & --- \\
\hline 30 & 3.8 & --- & 45 & 4.9 & 2.9 & 2.7 & 63 & 4.2 & --- & --- & --- & --- \\
\hline 31 & 3.9 & --- & 30 & --- & 3.1 & --- & 63 & 4.1 & --- & --- & --- & --- \\
\hline TOTAL & 118.2 & 106.6 & $3,745.70$ & 188 & 123.1 & 88.4 & 639.6 & $1,574.40$ & --- & --- & --- & --- \\
\hline MEAN & 3.81 & 3.81 & 121 & 6.27 & 3.97 & 2.95 & 20.6 & 50.8 & --- & --- & --- & --- \\
\hline MAX & 4.4 & 6.1 & 501 & 22 & 5.3 & 3.8 & 200 & 282 & --- & --- & --- & --- \\
\hline MIN & 3.1 & 2.8 & 4.1 & 3.2 & 2 & 1.7 & 2.8 & 3.9 & --- & --- & --- & --- \\
\hline ACRE-FT & 234 & 211 & 7,430 & 373 & 244 & 175 & 1,270 & 3,120 & --- & --- & --- & --- \\
\hline
\end{tabular}


Table 12. Locations and descriptions of C-aquifer baseflow investigation sites included in this study, northeastern Arizona.

[Latitude and longitude are in degrees, minutes, and seconds and referenced to NAD 83; ft, feet; dashes, information not available; LCR, Little Colorado River; , about; mi., miles; R., River; Cr., Creek]

\begin{tabular}{|c|c|c|c|c|c|c|}
\hline Station name & $\begin{array}{l}\text { River miles } \\
\text { upstream } \\
\text { of LCR } \\
\text { confluence }\end{array}$ & Station description & $\begin{array}{c}\text { U.S. Geological } \\
\text { Survey } \\
\text { identification } \\
\text { number }\end{array}$ & Latitude & Longitude & $\begin{array}{c}\text { Land-surface } \\
\text { altitude } \\
\text { (ft above } \\
\text { NAVD29) }\end{array}$ \\
\hline \multicolumn{7}{|c|}{ Little Colorado River Sites } \\
\hline Chevelon Site 1 & --- & $\begin{array}{l}1,2,3,4 \text { Little Colorado R. } \sim 600 \mathrm{ft} \\
\text { below Chevelon Cr. confluence }\end{array}$ & 345706110315300 & $34^{\circ} 57^{\prime} 06^{\prime \prime}$ & $-110^{\circ} 31^{\prime} 53^{\prime \prime}$ & 4,885 \\
\hline Chevelon Site 1a & --- & $\begin{array}{l}1,2,4 \text { Little Colorado R. } \sim 1.2 \text { mi. } \\
\text { below Chevelon Cr. confluence }\end{array}$ & 345732110323400 & $34^{\circ} 57^{\prime} 32^{\prime \prime}$ & $-110^{\circ} 32^{\prime} 34^{\prime \prime}$ & 4,880 \\
\hline Chevelon Site 1b & -- & $\begin{array}{l}{ }^{1,2,3,4} \text { Little Colorado R. } \sim 2.7 \text { mi. } \\
\text { below Chevelon Cr. confluence }\end{array}$ & 345805110331400 & $34^{\circ} 58^{\prime} 05^{\prime \prime}$ & $-110^{\circ} 33^{\prime} 14^{\prime \prime}$ & 4,875 \\
\hline Chevelon Site 1c & --- & $\begin{array}{l}{ }^{2,3,4} \text { Little Colorado R. } \sim 3.5 \mathrm{mi} \\
\text { below Chevelon Cr. confluence }\end{array}$ & 345900110335300 & $34^{\circ} 59^{\prime} 00^{\prime \prime}$ & $-110^{\circ} 33^{\prime} 53^{\prime \prime}$ & 4,880 \\
\hline Chevelon Site 2 & -- & $\begin{array}{l}{ }^{2,3} \text { Little Colorado R.. } \sim 400 \mathrm{ft} \\
\text { above Chevelon Cr. confluence }\end{array}$ & 345708110311700 & $34^{\circ} 57^{\prime} 08^{\prime \prime}$ & $-110^{\circ} 31^{\prime} 17^{\prime \prime}$ & 4,885 \\
\hline Clear Site 1 & -- & ${ }^{1,2,3,4}$ Little Colorado R. below Clear Cr. confluence & 345913110381800 & $34^{\circ} 59^{\prime} 13^{\prime \prime}$ & $-110^{\circ} 38^{\prime} 18^{\prime \prime}$ & 4,856 \\
\hline Clear Site 2 & --- & 1,2,3,4 Little Colorado R. above Clear Cr. confluence & 345913110381700 & $34^{\circ} 59^{\prime} 13^{\prime \prime}$ & $-110^{\circ} 38^{\prime} 17^{\prime \prime}$ & 4,856 \\
\hline \multicolumn{7}{|c|}{ Chevelon Creek Sites } \\
\hline Chevelon Site 3 & 0.39 & ${ }^{1,2,3,4}$ Chevelon Cr. $\sim 0.5$ mi. above mouth & 345658110311100 & $34^{\circ} 56^{\prime} 58^{\prime \prime}$ & $-110^{\circ} 31^{\prime} 11^{\prime \prime}$ & 4,897 \\
\hline Chevelon Site 4 & 0.86 & ${ }^{1,2,3,4}$ Chevelon $\mathrm{Cr} . \sim 450 \mathrm{ft}$ downstream of dam & 345636110305400 & $34^{\circ} 56^{\prime} 36^{\prime \prime}$ & $-110^{\circ} 30^{\prime} 54^{\prime \prime}$ & 4,902 \\
\hline Chevelon Site 5 & 0.89 & ${ }^{1,2,4}$ Chevelon Cr. $\sim 150 \mathrm{ft}$ downstream of dam & 345636110305400 & $34^{\circ} 56^{\prime} 36^{\prime \prime}$ & $-110^{\circ} 30^{\prime} 54^{\prime \prime}$ & 4,902 \\
\hline Chevelon Site 9 & 1.76 & ${ }^{1,2}$ Chevelon Cr. downstream from gage $\sim 1.5 \mathrm{mi}$. & 345558110305600 & $34^{\circ} 55^{\prime} 58^{\prime \prime}$ & $-110^{\circ} 30^{\prime} 56^{\prime \prime}$ & 4,905 \\
\hline Chevelon Site 6 & 3.42 & ${ }^{1,2,4}$ Spring \#1 on Chevelon Cr. & 345519110314201 & $34^{\circ} 55^{\prime} 19^{\prime \prime}$ & $-110^{\circ} 31^{\prime} 42^{\prime \prime}$ & 4,906 \\
\hline Chevelon Site 8 & 3.66 & ${ }^{1}$ Spring \#2 on Chevelon Cr. & 345511110313201 & $34^{\circ} 55^{\prime} 10^{\prime \prime}$ & $-110^{\circ} 31^{\prime} 32^{\prime \prime}$ & 4,909 \\
\hline Chevelon Site 7 & 3.67 & ${ }^{1,2}$ Chevelon Cr. near Spring \#2 & 345510110313200 & $34^{\circ} 55^{\prime} 10^{\prime \prime}$ & $-110^{\circ} 31^{\prime} 32^{\prime \prime}$ & 4,907 \\
\hline Chevelon Site 11 & 7.60 & ${ }^{1,2,4}$ Chevelon Cr. at Rock Art access & 345305110303700 & $34^{\circ} 53^{\prime} 05^{\prime \prime}$ & $-110^{\circ} 30^{\prime} 37^{\prime \prime}$ & 5,006 \\
\hline Chevelon Site 10 & 8.03 & ${ }^{1,2,4}$ Chevelon Cr. above Bell Cow Canyon & 345251110305700 & $34^{\circ} 52^{\prime} 51^{\prime \prime}$ & $-110^{\circ} 30^{\prime} 57^{\prime \prime}$ & 5,015 \\
\hline Chevelon Site 12 & 9.39 & $\begin{array}{l}{ }^{2.4} \text { Chevelon Cr. half-way between } \\
\text { Bell Cow and Babbitt Tank Canyon }\end{array}$ & 345214110315300 & $34^{\circ} 52^{\prime} 14^{\prime \prime}$ & $-110^{\circ} 31^{\prime} 53 "$ & --- \\
\hline Chevelon Site 13 & 11.59 & ${ }^{1,2}$ Chevelon Cr. above Babbitt Tank Canyon & 345026110322300 & $34^{\circ} 50^{\prime} 26^{\prime \prime}$ & $-110^{\circ} 32^{\prime} 23^{\prime \prime}$ & -- \\
\hline \multicolumn{7}{|c|}{$\begin{array}{ll}\text { Clear Creek Sites } \\
\end{array}$} \\
\hline Clear Site 2a & 0.00 & ${ }^{2,4} \mathrm{Clear} \mathrm{Cr} . \sim 5 \mathrm{ft}$ above the mouth & 345919110382300 & $34^{\circ} 59^{\prime} 19^{\prime \prime}$ & $-110^{\circ} 38^{\prime} 23^{\prime \prime}$ & 4,860 \\
\hline Clear Site 9 & 0.50 & ${ }^{4}$ Clear $\mathrm{Cr}$. at aquaduct pipe & 345847110382300 & $34^{\circ} 58^{\prime} 47^{\prime \prime}$ & $-110^{\circ} 38^{\prime} 23^{\prime \prime}$ & 4,857 \\
\hline Clear Site 3 & 1.15 & ${ }^{1,2} \mathrm{Clear} \mathrm{Cr}$. below springs, below dam & 345906110383301 & $34^{\circ} 58^{\prime} 16^{\prime \prime}$ & $-110^{\circ} 38^{\prime} 28^{\prime \prime}$ & 4,858 \\
\hline Clear Site 4 & 1.18 & ${ }^{1,2,4}$ Artesian spring on Clear Cr. below dam & 345813110382701 & $34^{\circ} 58^{\prime} 13^{\prime \prime}$ & $-110^{\circ} 38^{\prime} 27^{\prime \prime}$ & 4,860 \\
\hline Clear Site 6 & 1.18 & ${ }^{1,2}$ Main artesian spring on Clear Cr. below dam & 345859110381801 & $34^{\circ} 58^{\prime} 10^{\prime \prime}$ & $-110^{\circ} 38^{\prime} 18^{\prime \prime}$ & 4,860 \\
\hline Clear Site $7 \mathrm{a}$ & 1.19 & ${ }^{1,2}$ Diversion below aquaduct on Clear $\mathrm{Cr}$. & 345814110382900 & $34^{\circ} 58^{\prime} 14^{\prime \prime}$ & $-110^{\circ} 38^{\prime} 29^{\prime \prime}$ & 4,865 \\
\hline Clear Site 5 & 1.24 & $\begin{array}{l}\text { 1,2,4 Spring upstream from main } \\
\text { artesian spring on Clear Cr. }\end{array}$ & 345811110383001 & $34^{\circ} 58^{\prime} 11^{\prime \prime}$ & $-110^{\circ} 38^{\prime} 30^{\prime \prime}$ & 4,860 \\
\hline Clear Site $7 b$ & 1.24 & ${ }_{1,2,3,4}$ Spring near diversion canal on Clear Cr. & 345812110383101 & $34^{\circ} 58^{\prime} 12^{\prime \prime}$ & $-110^{\circ} 38^{\prime} 31^{\prime \prime}$ & 4,870 \\
\hline Clear Site 11 & 3.95 & ${ }^{1,2}$ Clear Cr. $\sim 2$ mi. upstream of Hwy 99 & 345651110394100 & $34^{\circ} 56^{\prime} 51^{\prime \prime}$ & $-110^{\circ} 39^{\prime} 41^{\prime \prime}$ & 4,865 \\
\hline Clear Site 12 & 4.12 & ${ }^{1,2} \mathrm{Clear} \mathrm{Cr}$. $\sim 2.3$ mi. upstream of Hwy 99 & 345643110394600 & $34^{\circ} 56^{\prime} 43^{\prime \prime}$ & $-110^{\circ} 39^{\prime} 46^{\prime \prime}$ & 4,867 \\
\hline Clear Site 13 & 4.27 & ${ }^{1,4} \mathrm{Clear}$ Cr. $\sim 2.6$ mi. upstream of Hwy 99 & 345637110394900 & $34^{\circ} 567^{\prime} 37^{\prime \prime}$ & $-110^{\circ} 39^{\prime} 49^{\prime \prime}$ & 4,868 \\
\hline Clear Site 14 & 6.40 & ${ }^{2}$ Clear Cr. $\sim 3.4$ mi. upstream of Hwy 99 & 345606110400300 & $34^{\circ} 56^{\prime} 06^{\prime \prime}$ & $-110^{\circ} 40^{\prime} 03^{\prime \prime}$ & 4,885 \\
\hline Clear Site OBS1 & 6.77 & ${ }^{1}$ Clear Cr. $\sim 2.0$ mi below start of perennial flow & 345530110411500 & $34^{\circ} 55^{\prime} 30^{\prime \prime}$ & $-110^{\circ} 41^{\prime} 15^{\prime \prime}$ & 4,935 \\
\hline Clear Site OBS2 & 8.74 & ${ }^{2}$ Clear Cr. at start of perennial flow & 345502110423000 & $34^{\circ} 55^{\prime} 02^{\prime \prime}$ & $-110^{\circ} 42^{\prime} 30^{\prime \prime}$ & 4,975 \\
\hline
\end{tabular}

${ }^{1}$ Visited during 2005 baseflow investigation.

${ }^{2}$ Visited during 2006 baseflow investigation.

${ }^{3}$ Visited during 2008 baseflow investigation.

${ }^{4}$ Visited during 2010 baseflow investigation. 
Table 13. Measured field parameters at C-aquifer baseflow investigation sites along Clear Creek, Chevelon Creek, and Little Colorado River (LCR), northeastern Arizona.

$\left[{ }^{\circ} \mathrm{C}\right.$, degrees Celsius; $\mu \mathrm{S} / \mathrm{cm}$, microsiemens per centimeter at $25^{\circ} \mathrm{C} ; \mathrm{mg} / \mathrm{L}$, milligrams per liter; $\mu \mathrm{g} / \mathrm{L}$, micrograms per liter; E, estimated; <, less than; $\mathrm{ft} 3 / \mathrm{s}$, cubic feet per second; Dashes indicate no data; USGS, U.S. Geological Survey; LCR, Little Colorado River]

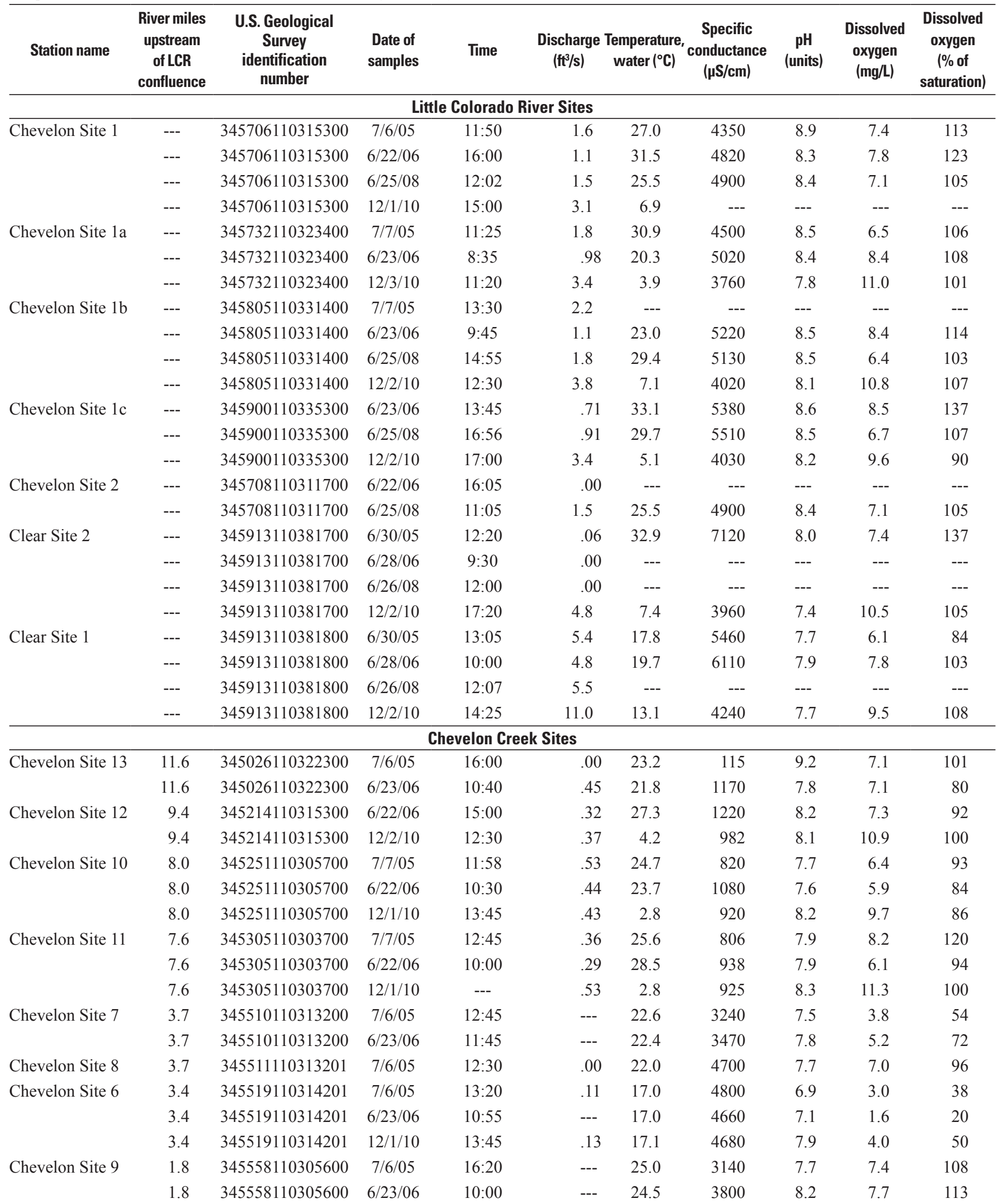


Table 13. Measured field parameters at C-aquifer baseflow investigation sites along Clear Creek, Chevelon Creek, and Little Colorado River (LCR), northeastern Arizona.-Continued.

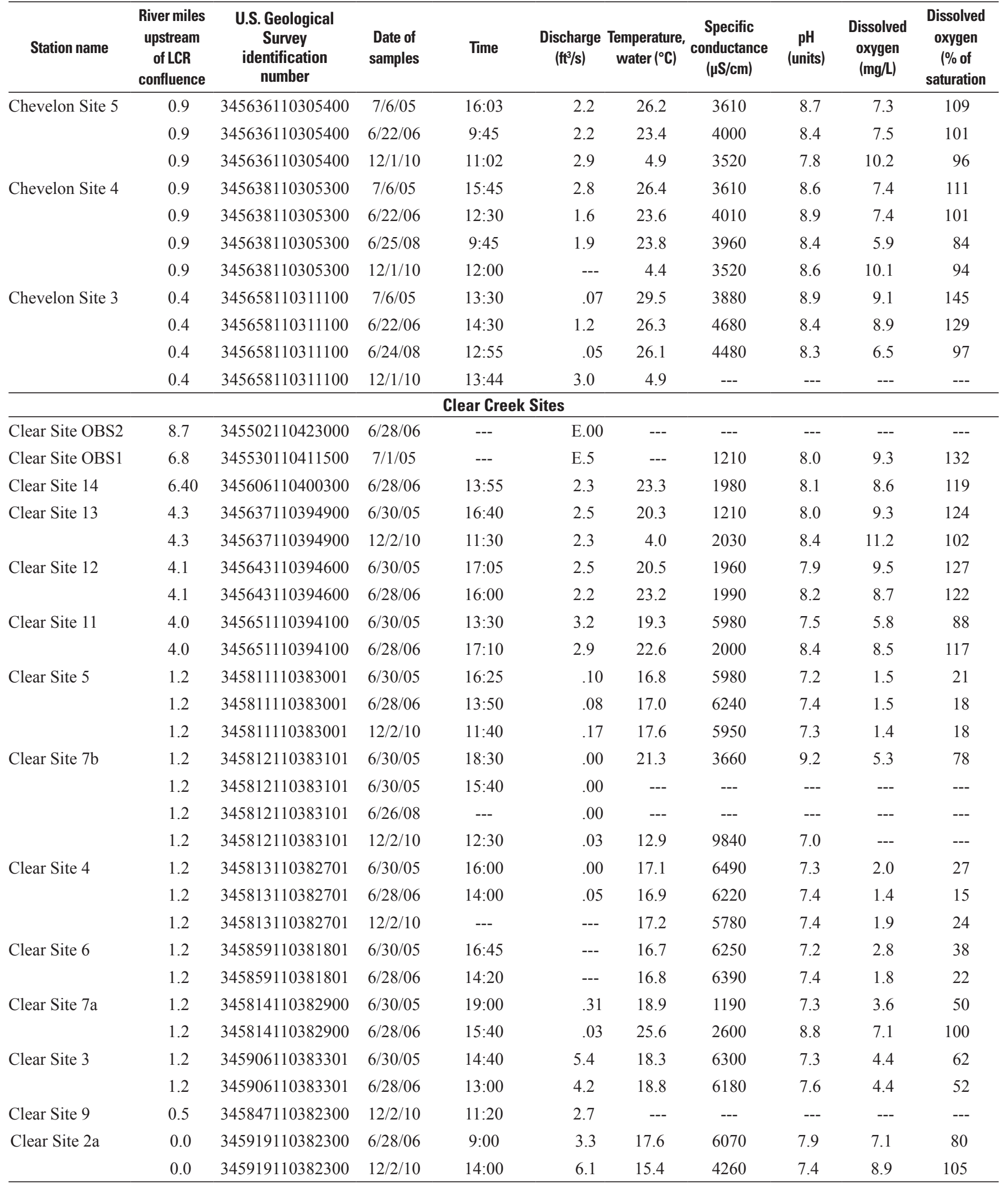


Table 14. Physical and chemical analyses of water samples from selected C-aquifer wells, Little Colorado River basin, northeastern Arizona.

$\left[{ }^{\circ} \mathrm{C}\right.$, degrees Celsius; $\mu \mathrm{S} / \mathrm{cm}$, microsiemens per centimeter at $25^{\circ} \mathrm{C} ; \mathrm{mg} / \mathrm{L}$, milligrams per liter; $\mu \mathrm{g} / \mathrm{L}$, micrograms per liter; E, estimated; $\mathrm{U}$, analyzed for but not detected; $<$, less than. Dashes indicate no data.]

\begin{tabular}{|c|c|c|c|c|c|c|c|c|c|c|c|c|}
\hline \multirow[b]{2}{*}{$\begin{array}{l}\text { Common } \\
\text { well name }\end{array}$} & \multirow[b]{2}{*}{$\begin{array}{l}\text { U.S. Geological } \\
\text { Survey } \\
\text { identification } \\
\text { number }\end{array}$} & \multirow[b]{2}{*}{$\begin{array}{l}\text { Date of } \\
\text { samples }\end{array}$} & \multirow[b]{2}{*}{ Time } & \multirow[b]{2}{*}{$\begin{array}{l}\text { Tempera- } \\
\text { ture, } \\
\text { field }\left({ }^{\circ} \mathrm{C}\right)\end{array}$} & \multirow[b]{2}{*}{$\begin{array}{c}\text { Specific } \\
\text { conductance', } \\
\text { field }(\mu \mathrm{S} / \mathrm{cm})\end{array}$} & \multirow[b]{2}{*}{$\begin{array}{c}\mathrm{pH}^{2} \text {, } \\
\text { field } \\
\text { (units) }\end{array}$} & \multicolumn{6}{|c|}{ Dissolved, in mg/L } \\
\hline & & & & & & & $\begin{array}{l}\text { Alkalinity }{ }^{3} \text {, } \\
\text { field } \\
\left(\mathrm{CaCO}_{3}\right)\end{array}$ & $\begin{array}{l}\text { Nitrogen } \\
\mathrm{NO}_{2}+\mathrm{NO}_{3} \\
(\mathrm{~N})\end{array}$ & $\begin{array}{l}\text { Ortho- } \\
\text { Phos- } \\
\text { phate } \\
\text { (P) }\end{array}$ & $\begin{array}{l}\text { Calcium } \\
\text { (Ca) }\end{array}$ & $\begin{array}{l}\text { Magnesium } \\
\quad(\mathrm{Mg})\end{array}$ & $\begin{array}{l}\text { Potassium } \\
\text { (K) }\end{array}$ \\
\hline \multirow[t]{2}{*}{ TEP M-6 } & 342024109220301 & $8 / 7 / 85$ & $15: 00$ & 18.0 & 1150 & 6.9 & $229^{3}$ & $<.10$ & $<.01$ & 94.0 & 26.0 & 19.0 \\
\hline & 342024109220301 & $8 / 7 / 85$ & $16: 00$ & 18.0 & 1150 & 6.9 & $229^{3}$ & $<.10$ & 3.60 & 89.0 & 27.0 & 11.0 \\
\hline \multirow{5}{*}{$\begin{array}{l}\text { Winslow } \\
\text { T-Well }\end{array}$} & 345603110450301 & $8 / 4 / 69$ & --- & 17.5 & 4380 & 7.9 & $244^{3}$ & --- & --- & 44.3 & 24.2 & 4.69 \\
\hline & 345603110450301 & $8 / 5 / 69$ & --- & 17.5 & 4740 & 8.2 & $266^{3}$ & --- & --- & 41.1 & 25.4 & 6.26 \\
\hline & 345603110450301 & $8 / 6 / 69$ & --- & 17.5 & 4420 & 7.8 & $233^{3}$ & --- & --- & 54.0 & 31.1 & 4.70 \\
\hline & 345603110450301 & $8 / 7 / 69$ & --- & 17.5 & 2880 & 7.8 & $236^{3}$ & --- & --- & 50.1 & 22.0 & 3.91 \\
\hline & 345603110450301 & $8 / 8 / 69$ & --- & 17.5 & 3020 & 7.7 & $192^{3}$ & --- & --- & 120 & 20.4 & 5.90 \\
\hline $\begin{array}{l}\text { Winslow } \\
\text { I-40 Well }\end{array}$ & 350002110355501 & $6 / 16 / 72$ & --- & 17.0 & 5870 & 7.5 & 220 & .01 & .010 & 150 & 64.0 & 7.50 \\
\hline Tucker Mesa & 350446110502501 & $8 / 22 / 06$ & $10: 40$ & --- & 2870 & 8.1 & $198^{3}$ & .38 & .008 & 75.5 & 35.6 & 1.99 \\
\hline \multirow{5}{*}{$\begin{array}{l}\text { Sunshine } \\
\text { Well }\end{array}$} & 350706111014701 & $11 / 20 / 33$ & --- & --- & --- & --- & $185^{3}$ & --- & --- & 108 & 50.0 & --- \\
\hline & 350706111014701 & $3 / 3 / 53$ & --- & --- & 859 & --- & $170^{3}$ & --- & --- & 98.0 & 47.0 & --- \\
\hline & 350706111014701 & $10 / 12 / 78$ & --- & 20.0 & 850 & 7.6 & $160^{3}$ & .010 & --- & 89.0 & 41.0 & 1.70 \\
\hline & 350706111014701 & $2 / 28 / 05$ & $10: 30$ & 16.8 & 860 & 7.5 & 178 & --- & $<.006$ & 107 & 45.5 & 1.74 \\
\hline & 350706111014701 & $2 / 28 / 05$ & $12: 45$ & 17.0 & 856 & 7.5 & 170 & --- & $<.006$ & 106 & 44.9 & 1.68 \\
\hline Lake Mary 1 & 350716111354401 & $3 / 11 / 63$ & --- & 18.0 & 411 & 7.5 & $210^{3}$ & --- & --- & 44.0 & 25.0 & 2.00 \\
\hline \multirow[t]{4}{*}{ PW-3 } & 350957110562601 & $2 / 9 / 05$ & $20: 30$ & 16.0 & 1230 & 8.3 & 178 & --- & $<.006$ & 88.6 & 43.5 & 5.15 \\
\hline & 350957110562601 & $2 / 24 / 05$ & $12: 45$ & 18.4 & 1160 & 7.9 & 192 & --- & $<.006$ & 102 & 52.8 & 2.23 \\
\hline & 350957110562601 & $2 / 24 / 05$ & $17: 30$ & 16.4 & 1160 & 7.8 & 182 & --- & $<.006$ & 104 & 53.5 & 2.47 \\
\hline & 350957110562601 & $3 / 23 / 05$ & 13:00 & --- & 1140 & $7.8^{2}$ & --- & --- & $<.02$ & 106 & 55.0 & 2.18 \\
\hline \multirow[t]{3}{*}{ OW-1 } & 351022111061801 & $2 / 21 / 05$ & $23: 30$ & 17.8 & 1180 & 8.1 & 161 & --- & $<.006$ & 122 & 56.7 & 2.21 \\
\hline & 351022111061801 & $2 / 25 / 05$ & $12: 00$ & 18.2 & 1180 & 7.6 & 153 & --- & $<.006$ & 125 & 59.2 & 2.50 \\
\hline & 351022111061801 & $2 / 25 / 05$ & $15: 30$ & 18.0 & 1190 & 7.6 & 155 & --- & $<.006$ & 127 & 59.5 & 2.40 \\
\hline \multirow[t]{4}{*}{ PW-1A } & 351023111062002 & $2 / 13 / 05$ & 19:00 & 17.6 & 1170 & 8.0 & 159 & --- & $<.006$ & 110 & 51.6 & 2.13 \\
\hline & 351023111062002 & $2 / 19 / 05$ & $12: 30$ & 18.7 & 1160 & 7.8 & 142 & --- & $<.006$ & 124 & 57.8 & 2.27 \\
\hline & 351023111062002 & $2 / 19 / 05$ & $17: 00$ & 18.2 & 1170 & 7.6 & 145 & --- & $<.006$ & 124 & 58.1 & 2.16 \\
\hline & 351023111062002 & $3 / 15 / 05$ & $13: 00$ & --- & $1120^{1}$ & $7.7^{2}$ & --- & --- & $<.02$ & 127 & 59.2 & 2.21 \\
\hline \multirow{4}{*}{$\begin{array}{l}\text { NPS Walnut } \\
\text { Canyon }\end{array}$} & 351025111303701 & $8 / 19 / 70$ & --- & 15.5 & 380 & 8.0 & 203 & --- & --- & 42.0 & 26.0 & .80 \\
\hline & 351025111303701 & $7 / 26 / 95$ & $12: 30$ & 12.0 & 400 & 7.8 & 195 & 1.40 & $<.01$ & 43.0 & 24.0 & 1.00 \\
\hline & 351025111303701 & $6 / 11 / 96$ & $15: 10$ & 14.6 & 409 & 7.5 & 199 & 1.60 & .01 & 45.0 & 22.0 & .90 \\
\hline & 351025111303701 & $9 / 20 / 01$ & $12: 20$ & 14.0 & 399 & 7.7 & 203 & 1.43 & $<.02$ & 43.4 & 24.7 & .97 \\
\hline \multirow[t]{4}{*}{ PW-2B } & 351213111022101 & $4 / 12 / 05$ & $19: 10$ & 16.2 & 837 & 7.8 & 184 & --- & $<.006$ & 91.9 & 42.0 & 1.87 \\
\hline & 351213111022101 & $4 / 20 / 05$ & $15: 30$ & 17.5 & 849 & 7.3 & 163 & --- & $<.006$ & 97.0 & 41.3 & 1.97 \\
\hline & 351213111022101 & $4 / 20 / 05$ & $20: 25$ & 16.8 & 850 & 7.2 & 160 & --- & $<.006$ & 99.6 & 41.9 & 1.98 \\
\hline & 351213111022101 & $5 / 9 / 05$ & $10: 00$ & --- & $802^{1}$ & $7.5^{2}$ & --- & --- & $<.02$ & 98.7 & 45.0 & 1.81 \\
\hline \multirow[t]{2}{*}{ OW-2B } & 351214111022101 & $4 / 22 / 05$ & $12: 15$ & 18.1 & 841 & 7.4 & 165 & --- & $<.006$ & 98.3 & 42.6 & 1.81 \\
\hline & 351214111022101 & $4 / 22 / 05$ & $15: 30$ & 17.5 & 842 & 7.4 & 165 & --- & $<.006$ & 100 & 43.5 & 1.82 \\
\hline $\begin{array}{l}\text { NPS Sunset } \\
\text { Crater }\end{array}$ & 352214111324601 & $5 / 5 / 65$ & --- & 15.5 & 945 & 6.9 & $528^{3}$ & --- & --- & 148 & 35.0 & 2.20 \\
\hline NPS Citadel & 353410111284001 & $1 / 25 / 67$ & --- & 20.0 & 1050 & 7.4 & 371 & --- & --- & 102 & 48.0 & --- \\
\hline
\end{tabular}


Table 14. Physical and chemical analyses of water samples from selected C-aquifer wells, Little Colorado River basin, northeastern Arizona.-Continued.

\begin{tabular}{|c|c|c|c|c|c|c|c|c|c|c|c|c|}
\hline \multirow[b]{2}{*}{$\begin{array}{l}\text { Common } \\
\text { well name }\end{array}$} & \multirow{2}{*}{$\begin{array}{l}\text { U.S. Geological } \\
\text { Survey } \\
\text { identification } \\
\text { number }\end{array}$} & \multirow[b]{2}{*}{$\begin{array}{c}\text { Date of } \\
\text { samples }\end{array}$} & \multirow[b]{2}{*}{ Time } & \multicolumn{5}{|c|}{ Dissolved, in mg/L } & \multicolumn{3}{|c|}{ Dissolved, in $\mu \mathrm{g} / \mathrm{L}$} & \multirow{2}{*}{$\begin{array}{c}\text { Dissolved } \\
\text { solids } \\
\text { residue } \\
\text { at } 180^{\circ} \mathrm{C} \\
\text { (mg/L) }\end{array}$} \\
\hline & & & & $\begin{array}{l}\text { Sodium } \\
\text { (Na) }\end{array}$ & $\begin{array}{l}\text { Chloride } \\
\text { (CI) }\end{array}$ & $\begin{array}{l}\text { Flouride } \\
\text { (F) }\end{array}$ & $\begin{array}{l}\text { Silica } \\
\left(\mathrm{SiO}_{2}\right)\end{array}$ & $\begin{array}{l}\text { Sulfate } \\
\left(\mathrm{SO}_{4}\right)\end{array}$ & $\begin{array}{c}\text { Arsenic } \\
\text { (As) }\end{array}$ & $\begin{array}{l}\text { Boron } \\
\text { (B) }\end{array}$ & $\begin{array}{l}\text { Iron } \\
(\mathrm{Fe})\end{array}$ & \\
\hline \multirow[t]{2}{*}{ TEP M-6 } & 342024109220301 & $8 / 7 / 85$ & $15: 00$ & 110 & 170 & 2.80 & 5.90 & 120 & --- & 210 & 3000 & --- \\
\hline & 342024109220301 & $8 / 7 / 85$ & $16: 00$ & 110 & 170 & 2.80 & 5.70 & 120 & --- & 220 & 2900 & --- \\
\hline \multirow{5}{*}{$\begin{array}{l}\text { Winslow } \\
\text { T-Well }\end{array}$} & 345603110450301 & $8 / 4 / 69$ & --- & 843 & 1140 & .38 & 8.00 & 229 & --- & 120 & --- & --- \\
\hline & 345603110450301 & $8 / 5 / 69$ & --- & 947 & 1210 & .38 & 10.0 & 295 & --- & 130 & --- & --- \\
\hline & 345603110450301 & $8 / 6 / 69$ & --- & 855 & 1150 & .40 & 10.0 & 280 & --- & 210 & --- & --- \\
\hline & 345603110450301 & $8 / 7 / 69$ & --- & 536 & 546 & .40 & 12.0 & 368 & --- & 90 & --- & --- \\
\hline & 345603110450301 & $8 / 8 / 69$ & --- & 513 & 479 & .60 & 14.0 & 617 & --- & 20 & --- & --- \\
\hline $\begin{array}{l}\text { Winslow } \\
\text { I- } 40 \text { Well }\end{array}$ & 350002110355501 & $6 / 16 / 72$ & --- & 1000 & 1500 & .20 & 10.0 & 52.0 & --- & --- & 10 & --- \\
\hline Tucker Mesa & 350446110502501 & $8 / 22 / 06$ & $10: 40$ & 428 & 698 & .19 & 9.81 & 145 & 1.2 & 82 & $<18$ & 1610 \\
\hline \multirow{5}{*}{$\begin{array}{l}\text { Sunshine } \\
\text { Well }\end{array}$} & 350706111014701 & $11 / 20 / 33$ & --- & --- & 26.0 & $\mathrm{U}$ & --- & 295 & --- & --- & --- & --- \\
\hline & 350706111014701 & $3 / 3 / 53$ & --- & --- & 22.0 & .30 & 7.60 & 269 & --- & --- & -- & --- \\
\hline & 350706111014701 & $10 / 12 / 78$ & --- & 25.0 & 23.0 & .20 & 10.0 & 240 & --- & 90 & $<10$ & --- \\
\hline & 350706111014701 & $2 / 28 / 05$ & $10: 30$ & 26.1 & 21.7 & .23 & 13.1 & 265 & .5 & 78 & 280 & 601 \\
\hline & 350706111014701 & $2 / 28 / 05$ & $12: 45$ & 26.1 & 21.6 & .22 & 13.0 & 265 & .5 & 79 & 214 & 610 \\
\hline Lake Mary 1 & 350716111354401 & $3 / 11 / 63$ & --- & 6.00 & 8.0 & .40 & 13.0 & 6.0 & --- & --- & --- & --- \\
\hline \multirow[t]{4}{*}{ PW-3 } & 350957110562601 & $2 / 9 / 05$ & $20: 30$ & 115 & 125 & .32 & 15.0 & 267 & 1.3 & 87 & 434 & 778 \\
\hline & 350957110562601 & $2 / 24 / 05$ & $12: 45$ & 75.3 & 123 & .25 & 13.3 & 250 & .4 & 87 & 176 & 768 \\
\hline & 350957110562601 & $2 / 24 / 05$ & $17: 30$ & 77.4 & 123 & .26 & 13.6 & 251 & .5 & 86 & 268 & 763 \\
\hline & 350957110562601 & $3 / 23 / 05$ & 13:00 & 72.9 & 121 & .25 & 13.5 & 247 & $<2$ & 84 & 92 & --- \\
\hline \multirow[t]{3}{*}{ OW-1 } & 351022111061801 & $2 / 21 / 05$ & $23: 30$ & 56.6 & 64.9 & .21 & 12.6 & 385 & .2 & 91 & 80 & 837 \\
\hline & 351022111061801 & $2 / 25 / 05$ & $12: 00$ & 59.1 & 65.4 & .22 & 13.1 & 386 & .5 & 102 & 794 & 832 \\
\hline & 351022111061801 & $2 / 25 / 05$ & $15: 30$ & 59.1 & 65.4 & .23 & 13.6 & 386 & 6 & 102 & 287 & 846 \\
\hline \multirow[t]{4}{*}{ PW-1A } & 351023111062002 & $2 / 13 / 05$ & 19:00 & 54.9 & 65.2 & .20 & 14.1 & 385 & .2 & 85 & $<6$ & 855 \\
\hline & 351023111062002 & $2 / 19 / 05$ & $12: 30$ & 58.4 & 66.1 & .24 & 14.0 & 384 & .3 & 93 & 572 & 832 \\
\hline & 351023111062002 & $2 / 19 / 05$ & $17: 00$ & 57.9 & 62.7 & .22 & 14.1 & 383 & .4 & 94 & 357 & 824 \\
\hline & 351023111062002 & $3 / 15 / 05$ & 13:00 & 57.4 & 64.6 & .21 & 14.6 & 379 & $<2$ & 93 & 65 & --- \\
\hline \multirow{4}{*}{$\begin{array}{l}\text { NPS Walnut } \\
\text { Canyon }\end{array}$} & 351025111303701 & $8 / 19 / 70$ & --- & 40.0 & 5.0 & .10 & 11.0 & 3.0 & --- & --- & $\mathrm{U}$ & --- \\
\hline & 351025111303701 & $7 / 26 / 95$ & $12: 30$ & 3.90 & 4.00 & $<.10$ & 10.0 & 1.90 & --- & $<10$ & $<3$ & --- \\
\hline & 351025111303701 & $6 / 11 / 96$ & $15: 10$ & 4.70 & 5.80 & .10 & 11.0 & 2.80 & $<1$ & 10 & 3 & --- \\
\hline & 351025111303701 & 9/20/01 & $12: 20$ & 4.42 & 5.44 & E.11 & 10.5 & 2.16 & .4 & E8 & $<10$ & 203 \\
\hline \multirow[t]{4}{*}{ PW-2B } & 351213111022101 & $4 / 12 / 05$ & $19: 10$ & 27.3 & 21.0 & .30 & 13.6 & 257 & E. 2 & 83 & E5 & 597 \\
\hline & 351213111022101 & $4 / 20 / 05$ & $15: 30$ & 27.8 & 20.8 & .26 & 14.1 & 257 & .7 & 93 & 50 & 597 \\
\hline & 351213111022101 & $4 / 20 / 05$ & $20: 25$ & 27.7 & 20.8 & .26 & 14.2 & 257 & 6 & 91 & 34 & 589 \\
\hline & 351213111022101 & $5 / 9 / 05$ & $10: 00$ & 26.2 & 20.6 & .23 & 13.6 & 254 & $<2$ & 81 & 51 & --- \\
\hline \multirow[t]{2}{*}{ OW-2B } & 351214111022101 & $4 / 22 / 05$ & $12: 15$ & 27.6 & 21.6 & .24 & 13.3 & 255 & E.2 & 82 & 512 & 589 \\
\hline & 351214111022101 & $4 / 22 / 05$ & $15: 30$ & 27.5 & 21.7 & .26 & 13.3 & 255 & .2 & 84 & 391 & 595 \\
\hline $\begin{array}{l}\text { NPS Sunset } \\
\text { Crater }\end{array}$ & 352214111324601 & $5 / 5 / 65$ & --- & 19.0 & 5.0 & .40 & 36.0 & 3.2 & --- & 20 & 20 & --- \\
\hline NPS Citadel & 353410111284001 & $1 / 25 / 67$ & --- & --- & 90.0 & .50 & 16.0 & 83.0 & --- & --- & --- & --- \\
\hline
\end{tabular}


Table 15. Physical and chemical analyses of spring and surface-water samples from the 2005 and 2006 baseflow investigations along Clear Creek, Chevelon Creek, and a

reach of the Little Colorado River, northeastern Arizona.

$\left[{ }^{\circ} \mathrm{C}\right.$, degrees Celsius; $\mu \mathrm{S} / \mathrm{cm}$, microsiemens per centimeter at $25^{\circ} \mathrm{C} ; \mathrm{mg} / \mathrm{L}$, milligrams per liter; $\mu \mathrm{g} / \mathrm{L}$, micrograms per liter; $\mathrm{E}$, estimated; $<$, less than; dashes indicate no data. $]$

\begin{tabular}{|c|c|c|c|c|c|c|c|c|c|c|c|c|c|}
\hline \multirow[b]{2}{*}{ Station Name } & \multirow[b]{2}{*}{$\begin{array}{l}\text { River miles } \\
\text { above LCR } \\
\text { confluence }\end{array}$} & \multirow[b]{2}{*}{$\begin{array}{c}\text { U.S. Geological } \\
\text { Survey identification } \\
\text { number }\end{array}$} & \multirow[b]{2}{*}{$\begin{array}{l}\text { Date of } \\
\text { Samples }\end{array}$} & \multirow[b]{2}{*}{ Time } & \multirow[b]{2}{*}{$\begin{array}{l}\text { Tempera- } \\
\text { ture field } \\
\quad\left({ }^{\circ} \mathrm{C}\right)\end{array}$} & \multirow[b]{2}{*}{$\begin{array}{c}\text { Specific } \\
\text { conductance } \\
\text { field }{ }^{1}(\mu S / \mathrm{cm})\end{array}$} & \multirow[b]{2}{*}{$\begin{array}{c}\text { pH, } \\
\text { field }^{2} \\
\text { (units) }\end{array}$} & \multicolumn{6}{|c|}{ Dissolved (mg/L) } \\
\hline & & & & & & & & $\begin{array}{l}\text { Alkalinity, } \\
\text { field }^{3}, \\
\left(\mathrm{CaCO}_{3}\right)\end{array}$ & $\begin{array}{l}\text { Nitrogen, } \\
\mathrm{NO}_{2}+\mathrm{NO}_{3} \\
\text { (N) }\end{array}$ & $\begin{array}{l}\text { Ortho- } \\
\text { Phosphate } \\
\text { (P) }\end{array}$ & $\begin{array}{l}\text { Calcium } \\
\text { (Ca) }\end{array}$ & $\begin{array}{l}\text { Magnesium } \\
\qquad(\mathrm{Mg})\end{array}$ & $\begin{array}{l}\text { Potassium } \\
\text { (K) }\end{array}$ \\
\hline Chevelon Site 1a & --- & 345732110323400 & $6 / 23 / 06$ & $8: 35$ & --- & $4,830^{1}$ & $8.4^{2}$ & $215^{3}$ & $<.06$ & $<.006$ & 69.4 & 54.2 & 8.02 \\
\hline Chevelon Site 1b & --- & 345805110331400 & $6 / 23 / 06$ & $9: 45$ & --- & $5,090^{1}$ & $8.5^{2}$ & $218^{3}$ & $<.06$ & E.003 & 72.8 & 55.6 & 7.87 \\
\hline \multirow[t]{2}{*}{ Chevelon Site 5} & 0.89 & 345636110305400 & $7 / 6 / 05$ & $16: 03$ & 26.2 & 3,610 & 8.7 & 196 & --- & E.005 & 67.0 & 44.4 & 6.69 \\
\hline & 0.89 & 345636110305400 & $6 / 23 / 06$ & 10:00 & --- & $3,970^{1}$ & $8.5^{2}$ & $180^{3}$ & $<.06$ & E.004 & 56.9 & 47.0 & 6.97 \\
\hline \multirow[t]{2}{*}{ Chevelon Site 6} & 3.42 & 345519110314201 & $7 / 6 / 05$ & $13: 20$ & 17.0 & 4,800 & 6.9 & 202 & --- & .009 & 86.8 & 58.8 & 6.63 \\
\hline & 3.42 & 345519110314201 & $6 / 23 / 06$ & $10: 55$ & --- & $4,750^{1}$ & $7.7^{2}$ & $206^{3}$ & .09 & .008 & 78.7 & 49.9 & 5.83 \\
\hline \multirow[t]{2}{*}{ Chevelon Site 11} & 7.60 & 345305110303700 & $7 / 7 / 05$ & $12: 45$ & 25.6 & 806 & 7.9 & 155 & --- & $<.006$ & 69.2 & 22.6 & 2.31 \\
\hline & 7.60 & 345305110303700 & $6 / 22 / 06$ & $10: 00$ & --- & $984^{1}$ & $8.0^{2}$ & $167^{3}$ & $<.06$ & E.006 & 72.3 & 24.4 & 1.68 \\
\hline Chevelon Site 13 & 11.59 & 345026110322300 & $6 / 23 / 06$ & $13: 00$ & --- & $1,070^{1}$ & $8.1^{2}$ & $147^{3}$ & $<.06$ & .010 & 79.0 & 24.0 & 1.65 \\
\hline Clear Site 1 & --- & 345913110381800 & $6 / 28 / 06$ & $10: 00$ & --- & 6,300 & 7.3 & 230 & $<.06$ & E.004 & 83.2 & 52.9 & 7.28 \\
\hline \multirow[t]{2}{*}{ Clear Site 3} & 1.15 & 345906110383301 & $6 / 30 / 05$ & $14: 40$ & 18.3 & $5,980^{1}$ & $7.8^{2}$ & $222^{3}$ & --- & E.004 & 98.3 & 68.1 & 8.86 \\
\hline & 1.15 & 345906110383301 & $6 / 28 / 06$ & $13: 00$ & --- & 6,250 & 7.2 & 233 & $<.06$ & E.003 & 89.8 & 57.2 & 7.97 \\
\hline \multirow[t]{2}{*}{ Clear Site 6} & 1.18 & 345859110381801 & $6 / 30 / 05$ & $16: 45$ & 16.7 & $6,180^{1}$ & $7.4^{2}$ & $222^{3}$ & --- & .006 & 92.9 & 65.3 & 8.58 \\
\hline & 1.18 & 345859110381801 & $6 / 28 / 06$ & $14: 30$ & --- & $1,980^{1}$ & $8.3^{2}$ & $178^{3}$ & $<.06$ & E.003 & 90.6 & 58.9 & 8.08 \\
\hline \multirow[t]{2}{*}{ Clear Site 14} & 6.40 & 345606110400300 & $6 / 28 / 06$ & $13: 55$ & --- & $5,900^{1}$ & $8.1^{2}$ & $226^{3}$ & .15 & E.003 & 45.9 & 24.1 & 1.73 \\
\hline & Biver miles & U.S. Geological & & & \multicolumn{5}{|c|}{ Dissolved (mg/L) } & \multicolumn{3}{|c|}{ Dissolved ( $\mu \mathrm{g} / \mathrm{L})$} & \\
\hline Station name & $\begin{array}{l}\text { above LCR } \\
\text { confluence }\end{array}$ & $\begin{array}{c}\text { Survey } \\
\text { identification } \\
\text { number }\end{array}$ & $\begin{array}{c}\text { Date of } \\
\text { samples }\end{array}$ & Time & $\begin{array}{l}\text { Sodium } \\
\text { (Na) }\end{array}$ & $\begin{array}{l}\text { Chloride } \\
\text { (CI) }\end{array}$ & $\begin{array}{l}\text { Flouride } \\
\text { (F) }\end{array}$ & $\begin{array}{l}\text { Silica } \\
\left(\mathrm{SiO}_{2}\right)\end{array}$ & $\begin{array}{c}\text { Sulfate } \\
\left(\mathrm{SO}_{4}\right)\end{array}$ & $\begin{array}{c}\text { Arsenic } \\
\text { (As) }\end{array}$ & $\begin{array}{l}\text { Boron } \\
\text { (B) }\end{array}$ & $\begin{array}{l}\text { Iron } \\
\text { (Fe) }\end{array}$ & $\begin{array}{c}\text { solids } \\
\text { residue at } \\
180^{\circ} \mathrm{C}(\mathrm{mg} / \mathrm{L})\end{array}$ \\
\hline Chevelon Site 1a & --- & 345732110323400 & $6 / 23 / 06$ & $8: 35$ & 794 & 1,330 & .30 & .99 & 210 & 2.0 & 126 & $<18$ & 2,750 \\
\hline Chevelon Site $1 \mathrm{~b}$ & --- & 345805110331400 & $6 / 23 / 06$ & $9: 45$ & 837 & 1,400 & .33 & 2.58 & 243 & 1.8 & 151 & E10 & 2,910 \\
\hline \multirow[t]{2}{*}{ Chevelon Site 5} & 0.89 & 345636110305400 & $7 / 6 / 05$ & $16: 03$ & 586 & 951 & .24 & 3.01 & 166 & 2.9 & 113 & 21 & 2,000 \\
\hline & 0.89 & 345636110305400 & $6 / 23 / 06$ & 10:00 & 656 & 1,070 & .26 & 1.01 & 172 & 2.7 & 89 & 59 & 2,230 \\
\hline \multirow[t]{2}{*}{ Chevelon Site 6} & 3.42 & 345519110314201 & $7 / 6 / 05$ & $13: 20$ & 790 & 1,280 & .31 & 11.0 & 255 & 1.2 & 170 & E5 & 2,710 \\
\hline & 3.42 & 345519110314201 & $6 / 23 / 06$ & $10: 55$ & 764 & 1,270 & .31 & 10.5 & 251 & 1.6 & 144 & $<18$ & 2,690 \\
\hline \multirow[t]{2}{*}{ Chevelon Site 11} & 7.60 & 345305110303700 & $7 / 7 / 05$ & $12: 45$ & 68.5 & 94.2 & .17 & 3.14 & 123 & 2.1 & 50 & 11 & 488 \\
\hline & 7.60 & 345305110303700 & $6 / 22 / 06$ & $10: 00$ & 88.4 & 117 & .21 & 5.03 & 156 & 3.5 & 49 & 18 & 602 \\
\hline Chevelon Site 13 & 11.59 & 345026110322300 & $6 / 23 / 06$ & 13:00 & 99.1 & 130 & .23 & 8.21 & 197 & 3.1 & 55 & 10 & 662 \\
\hline Clear Site 1 & --- & 345913110381800 & $6 / 28 / 06$ & 10:00 & 985 & 1,650 & .32 & 8.72 & 282 & .87 & 177 & $<18$ & 3,430 \\
\hline \multirow[t]{2}{*}{ Clear Site 3} & 1.15 & 345906110383301 & $6 / 30 / 05$ & $14: 40$ & 1,180 & 1,710 & .33 & 9.68 & 299 & $<.6$ & 193 & $<18$ & 3,500 \\
\hline & 1.15 & 345906110383301 & $6 / 28 / 06$ & $13: 00$ & 1,080 & 1,680 & .32 & 9.27 & 288 & .75 & 177 & $<18$ & 3,500 \\
\hline \multirow[t]{2}{*}{ Clear Site 6} & 1.18 & 345859110381801 & $6 / 30 / 05$ & $16: 45$ & 1,140 & 1,750 & .32 & 9.76 & 301 & $<.6$ & 199 & $<18$ & 3,590 \\
\hline & 1.18 & 345859110381801 & $6 / 28 / 06$ & $14: 30$ & 1,100 & 1,750 & .32 & 8.79 & 296 & .75 & 170 & $<18$ & 3,610 \\
\hline Clear Site 14 & 6.40 & 345606110400300 & $6 / 28 / 06$ & $13: 55$ & 295 & 498 & .16 & 7.05 & 36.9 & .96 & 52 & 11 & 1,070 \\
\hline
\end{tabular}

${ }^{1}$ Laboratory values for specific conductance were reported where field values were missing.

${ }^{2}$ Laboratory values for $\mathrm{pH}$ were reported where field values were missing.

${ }^{3}$ Field acid neutralization capacity (ANC) values were reported where field alkalinity values were missing. 


\section{References Cited}

Alley, W.M., Reilly, T.E., and Franke, O.L., 1999, Sustainability of ground-water resources: U.S. Geological Survey Circular $1186,79 \mathrm{p}$.

Appel, C.L., and Bills, D.J., 1980, Map showing groundwater conditions in the Canyon Diablo area, Coconino and Navajo Counties, Arizona, 1979: U.S. Geological Survey Open-File Report 80-747, scale 1:125,000.

Billingsley, G.H., Breed, W.J., and Beasley, D., 1980, Geologic cross section along Interstate 40-Kingman to Flagstaff, Arizona: Chandler, Arizona, Pagosa Press, Petrified Forest Museum Association in cooperation with Museum of Northern Arizona map sheet.

Bills, D.J., and Flynn, M.E., 2002, Hydrogeologic data for the Coconino Plateau and adjacent areas, Coconino and Yavapai Counties, Arizona: U.S. Geological Survey Open-File Report 02-265, 29 p.

Bills, D.J., Flynn, M.E., and Monroe, S.A., 2007, Hydrogeology of the Coconino Plateau and adjacent areas, Coconino and Yavapai Counties, Arizona: U.S. Geological Survey Scientific Investigations Report 2005-5222, 101 p., 4 plates.

Bills, D.J., Truini, Margot, Flynn, M.E., Pierce, H.A., Cathings, R.D., and Rymer, M.J., 2000, Hydrogeology of the regional aquifer near Flagstaff, Arizona, 1994-97: U.S. Geological Survey Water-Resources Investigations Report 00-4122, 142 p.

Brown, D.E., Carmony, N.B., and Turner, R.M., 1978, Drainage map of Arizona showing perennial streams and some important wetlands: Phoenix, Arizona Game and Fish Department, scale 1:1,000,000.

Cooley, M.E., Harshbarger, J.W., Akers, J.P., Hardt, W.F., and Hicks, O.N., 1969, Regional hydrogeology of the Navajo and Hopi Indian Reservations, Arizona, New Mexico, and Utah: U.S. Geological Survey Professional Paper 521-A, 61 p.

Darton, N.H., 1910, A reconnaissance of parts of northwestern New Mexico and northern Arizona: U.S. Geological Survey Bulletin 435, $88 \mathrm{p}$.

Gregory, H.E., 1916, The Navajo country-A geographic and hydrographic reconnaissance of parts of Arizona, New Mexico, and Utah: U.S. Geological Survey Water-Supply Paper 380, 219 p.

Harrell, M.A., and Eckel, E.B., 1939, Ground-water resources of the Holbrook region: U.S. Geological Survey WaterSupply Paper 836-B, 105 p.
Hart, R.J., Ward, J.J., Bills, D.J., and Flynn, M.E., 2002, Generalized hydrogeology and ground-water budget for the C Aquifer, Little Colorado River basin and parts of the Verde and Salt River basins, Arizona and New Mexico: U.S. Geological Survey Water-Resources Investigations Report 02-4026, 54 p.

Hoffmann, J.P., Phillips, J.V., Bills, D.J., and Halford, K.J., 2005, Geologic, hydrologic, and chemical data from the C aquifer, near Leupp, Arizona: U.S. Geological Survey Scientific Investigations Report 2005-5280, 49 p..

Johnson, P.W., 1962, Water in the Coconino Sandstone for the Snowflake-Hay Hollow area, Navajo County, Arizona: U.S Geological Survey Water-Supply Paper 1539-S, 46 p.

Leake, S.A., Hoffmann, J.P., and Dickinson, Jesse, E., 2005, Numerical ground-water change model of the $\mathrm{C}$ aquifer and effects of ground-water withdrawals on stream depletion in selected reaches of Clear Creek, Chevelon Creek, and the Little Colorado River, northeastern Arizona; U.S. Geological Survey Scientific Investigations Report 2005-5277, 39 p.

Mann, L.J., 1976, Ground-water resources and water use in southern Navajo County, Arizona: Phoenix, Arizona Water Commission Bulletin 10, 106 p.

Mann, L.J., 1979, Water budget and mathematical model of the C aquifer, southern Navajo County, Arizona: U.S. Geological Survey Open-File Report 79-348, 58 p.

Mann, L.J., and Nemecek, E.A., 1983, Geohydrology and water use in southern Apache County, Arizona: Phoenix, Arizona Department of Water Resources Bulletin 1, 86 p.

McGavock, E.H., Anderson, T.W., Moosburner, Otto, and Mann, L.J., 1986, Water resources of southern Coconino County, Arizona: Phoenix, Arizona Department of Water Resources Bulletin 4, 53 p.

Peter Mock Groundwater Consulting, Inc., 2003, Report of findings for the assessment of western Navajo-Hopi water supply needs, alternatives, and impacts: HDR Engineering, Inc. v. 3, appendix B-3, variously paged.

Southwest Ground-water Consultants, Inc., 2003, Report of findings for the assessment of western Navajo-Hopi water supply needs, alternatives, and impacts: HDR Engineering, Inc for U.S. Bureau of Reclamation, v. 3, appendix B-1:, 10 p.

S.S. Papadopulos and Associates, Inc., 2005, Groundwater flow model of the $\mathrm{C}$ aquifer in Arizona and New Mexico: Bethesda, Maryland, Prepared for the Salt River Project on behalf of, and for the use of the Mohave Generating station co-owners, S.S. Papadopulos and Associates, Inc., 121 p., $1 \mathrm{~cd}$. 
U.S. Environmental Protection Agency, 2009, National primary and secondary drinking water regulations: Washington, D.C., U.S. Environmental Protection Agency, EPA 816-F-09-004, accessed August 14, 2012 at http://water.epa.gov/drink/contaminants/index.cfm.

U.S. Fish and Wildlife Service, 2011, Biological assessment of the Arizona Game and Fish Department's statewide and urban fisheries stocking program for the years 2011-2021: Wildlife and Sport Fish Restoration Program, U.S. Fish and Wildlife Service, Albuquerque, New Mexico, 1818 p.

U.S. Geological Survey, 1978, Progress report on Black Mesa monitoring program-1977: U.S. Geological Survey Open-File Report 78-459, 38 p.
U.S. Geological Survey, 2012, USGS Water Data for the Nation: http://waterdata.usgs.gov/nwis,accessed March 21, 2012.

U.S. Geological Survey, variously dated, National field manual for the collection of water-quality data: U.S. Geological Survey Techniques of WaterResources Investigations, book 9, chaps. A1-A9. (Also available online at http://pubs.water.usgs.gov/ twri9A.)

U.S. Geological Survey, 2012, Water Science Glossary of Terms, base flow: http:/ga.water.usgs.gov/edu/ dictionary.html\#B, accessed March 21, 2012. 
Prepared in the Menlo Park Publishing Service Center Manuscript approved for publication, August 30, 2012 Edited by John Buursma and Peter H. Stauffer Layout and design by Jeanne S. DiLeo 


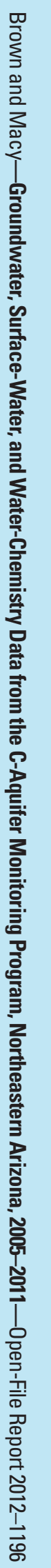

